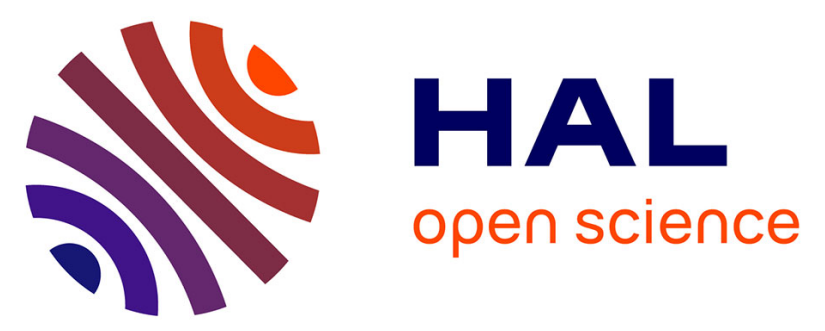

\title{
Clinoform identification and correlation in fine-grained sediments: A case study using the Triassic Montney Formation
}

Tiffany Playter, Hilary Corlett, Kurt O. Konhauser, Leslie Robbins, Sébastien Rohais, Vincent Crombez, Kelsey Maccormack, Dean Rokosh, Donald Prenoslo, Carolyn M Furlong, et al.

\section{To cite this version:}

Tiffany Playter, Hilary Corlett, Kurt O. Konhauser, Leslie Robbins, Sébastien Rohais, et al.. Clinoform identification and correlation in fine-grained sediments: A case study using the Triassic Montney Formation. Sedimentology, 2018, 65 (1), pp.263 - 302. 10.1111/sed.12403 . hal-01846967

\section{HAL Id: hal-01846967 \\ https://hal-ifp.archives-ouvertes.fr/hal-01846967}

Submitted on 24 Sep 2018

HAL is a multi-disciplinary open access archive for the deposit and dissemination of scientific research documents, whether they are published or not. The documents may come from teaching and research institutions in France or abroad, or from public or private research centers.
L'archive ouverte pluridisciplinaire HAL, est destinée au dépôt et à la diffusion de documents scientifiques de niveau recherche, publiés ou non, émanant des établissements d'enseignement et de recherche français ou étrangers, des laboratoires publics ou privés. 
Article type : Original Manuscript

Clinoform identification and correlation in fine-grained sediments: A case study using the Triassic Montney Formation

TIFFANY PLAYTER ${ }^{*+}$, HILARY CORLETT* ${ }^{*}$, KURT KONHAUSER ${ }^{\dagger}$, LESLIE ROBBINS $^{\dagger}$, SEBASTIEN ROHAIS $^{\ddagger}$, VINCENT CROMBEZ $^{\ddagger}$, KELSEY MACCORMACK*, DEAN ROKOSH* $^{*}$, DONALD PRENOSLO ${ }^{\dagger}$, CAROLYN M. FURLONG ${ }^{\dagger}$, JOHN PAWLOWICZ* $^{*}$, MURRAY GINGRAS $^{\dagger}$, STEFAN LALONDE $^{\S}$, STEVE LYSTER*,J-P ZONNEVELD ${ }^{+}$

* Alberta Geological Survey, 402, Twin Atria Building, 4999-98 Ave, Edmonton, Alberta, Canada, T6B $2 \times 3$

${ }^{+}$University of Alberta, 116 St. and 85 Ave, Edmonton, Alberta, Canada, T6G 2E3

" IFP Energies nouvelles Geoscience Division, Rueil-Malmaison, France

${ }^{\S}$ Institut Universitaire Européen de la Mer, Rue Dumont d'Urville, 29280 Plouzané, France

E-mail: tiffany.playter@aer.ca

Associate Editor - Tracy Fran

Short Title - Clinoforms in fine-grained sediments

This is an Accepted Article that has been peer-reviewed and approved for publication in the Sedimentology, but has yet to undergo copy-editing and proof correction. Please cite this article as an "Accepted Article"; doi: 10.1111/sed.12403

This article is protected by copyright. All rights reserved. 


\section{ABSTRACT}

Stratigraphic correlation of fine-grained successions is not always straightforward. Complicating factors such as unconformities, structural complexity, subsidence, and especially minimal grain-size variation, make the application of traditional correlation methods to fine-grained successions problematic. Alternatively, the analysis of detailed geochemical data can allow for the determination of variations in sediment provenance, mineralogy, detrital flux and hydrothermal input. When compared with modelled clay input over time, these geochemical indicators can be used to determine changes in relative sealevel and palaeoclimate, allowing for the identification of clinoform surfaces. As an example, this study outlines detailed correlations of chemostratigraphic packages within the lower Triassic Montney Formation in western Canada to demonstrate the effectiveness of chemostratigraphy in defining and correlating fine-grained clinoforms across a sedimentary basin. The data set used includes five wells and one outcrop succession, from which geochemical profiles were generated and tied directly to mineralogical data and well logs. These analyses reveal 13 distinct chemostratigraphic packages that correlate across the basin. Observed elemental and inferred mineralogical changes highlight trends in relative sea-level and palaeoclimate, as well as episodes of inferred hydrothermal input to the Montney basin. Cross-plots of $\mathrm{La} / \mathrm{Sm}$ and $\mathrm{Yb} / \mathrm{Sm}$ further suggest hydrothermal input as well as the scavenging of middle rare earth elements by phosphatic fish debris. Additionally, plots of $\mathrm{La} / \mathrm{Sm}$ versus $\mathrm{Yb} / \mathrm{Sm}$, which show volcanic arc input within the Doig Formation, suggest an additional sediment source from the west during the Anisian. Pairing detrital and clay proxies demonstrates changes in relative sea-level and, at the Smithian/Spathian boundary, the lowest relative sea-level in the Montney Formation is observed, corresponding to a change in climate.

This article is protected by copyright. All rights reserved. 
Keywords Chemostratigraphy, chronostratigraphy, clay proxies, correlation, detrital proxies, provenance proxies, relative sea-level, shale.

\section{INTRODUCTION}

Correlation of thick, fine-grained lithological successions often poses challenges that are commonly not resolvable through traditional stratigraphic techniques. These include: (i) minimal grain-size variation; (ii) lateral changes in unit thicknesses tied to structural features; (iii) differential subsidence and the occurrence of broad internal clinoform; and (iv) the occurrence of local and regional unconformities. Elemental chemostratigraphy provides a solution to these challenges by identifying lithological changes that are not apparent under direct observation, and in recent years it has been shown to be an invaluable tool for stratigraphic correlation in a number of successions (e.g. North et al., 2005; Hildred et al., 2010; Wright et al., 2010; Ratcliffe et al., 2015). Questions pertaining to regional anoxia (Retallack et al., 1997; Algeo et al., 2004; Ratcliffe et al., 2012), productivity (e.g. Hays et al., 2007), sediment provenance and source (Armstrong-Altrin et al., 2004; Pearce et al., 2005), as well as palaeoclimate (Armstrong-Altrin et al., 2004; Ratcliffe et al., 2010), have also been successfully investigated using chemostratigraphy.

Despite the wide applicability of chemostratigraphic analysis, it has largely been under-utilized in identifying and correlating chronostratigraphic surfaces (such as clinoforms). This paper outlines the application of chemostratigraphic analysis for determining chronostratigraphic surfaces in fine-grained sediments, using the Lower Triassic Montney Formation of Western Canada as an example. The Montney Formation is a finegrained, locally organic-rich formation deposited over a wide range of sedimentary environments, from the proximal to distal clastic ramp. 
Traditional methods of stratigraphic correlation often focus on lithology and fossil content; however, this method can be challenging in units of apparent lithological homogeneity (such as in thick shale or siltstone successions), especially when fossil evidence is sparse. Analyzing chemical trends allows for the identification of subtle mineralogy-based variations that cannot typically be identified by traditional correlation techniques. Geochemical proxies for clay input can be analyzed alongside proxies for sediment provenance, mineralogy and detrital influx. This provides a stratigraphic context that allows for genetically related deposits to be correlated.

The determination of provenance or redox specific information requires the use of specific elemental relationships or 'proxies', which can be selected on the basis of demonstrated correlation with specific factors, such as: the effects of oxidation state on the formation/alteration of some mineral components (e.g. Wedepohl, 1971; Arthur et al., 1990; Calvert \& Pedersen, 1993; Algeo et al., 2004; Algeo \& Lyons, 2006; Kendall et al., 2011; Asael et al., 2013; Chappaz et al., 2014; Reinhard et al., 2014; Planavsky et al., 2014), known effects of trace element sequestration due to biological activity and organic matter (e.g. Berner \& Westrich, 1985; Rabouille \& Gaillard, 1991; Fein et al., 1997; Tribovillard et al., 2006; Lalonde et al., 2008; Anbar \& Rouxel, 2007; Gadd, 2010; Liermann et al. 2011, Liang et al., 2013; Pokrovsky et al., 2014), the influence of weathering, palaeogeography and palaeoclimate on mineralogy (e.g. Plank \& Langmuir, 1998; Preston et al., 1998; Pearce et al., 1999, 2010; Hofmann et al., 2001; Hofer et al., 2013; Clift et al., 2014; Ratcliffe et al., 2015), the unique compositional signature of mafic/felsic/ultramafic source rocks (e.g. Reátegui et al., 2005) and diagenetic reactions (e.g. Froelich et al., 1979; Morton, 1985; Curtis et al., 1986; Canfield et al., 1993). 
The overarching goal of this work is a consistent, regional correlative framework of the Triassic Montney Formation. Geochemical elements and ratios used in this study were chosen to reflect indicators that are not: (i) heavily influenced by processes such as oxidation state (which can vary with water depth as well as with diagenesis); and (ii) palaeoproductivity (which can vary geographically). As such, this study used various elemental ratios, including: (i) clay indicators $\left(\mathrm{Cr} / \mathrm{Sc}, \mathrm{Zr} / \mathrm{La}, \mathrm{Zn} / \mathrm{Sc}, \mathrm{SiO}_{2} / \mathrm{Al}_{2} \mathrm{O}_{3}, \mathrm{Ga} / \mathrm{Rb}\right.$, $\mathrm{K}_{2} \mathrm{O} / \mathrm{Al}_{2} \mathrm{O}_{3}, \mathrm{~K}_{2} \mathrm{O} / \mathrm{Rb}, \mathrm{Na}_{2} \mathrm{O} / \mathrm{Al}_{2} \mathrm{O}_{3}, \mathrm{Rb} / \mathrm{Al}$; Plank \& Langmuir, 1998; Preston et al., 1998; Pearce et al., 1999, 2010; Hofmann et al., 2001; Hofer et al., 2013; Clift et al., 2014; Ratcliffe et al., 2015); (ii) detrital input and sediment recycling indicators $\left(\mathrm{TiO}_{2} / \mathrm{Al}_{2} \mathrm{O}_{3}, \mathrm{TiO}_{2} / \mathrm{K}_{2} \mathrm{O}\right.$, $\mathrm{Lu} / \mathrm{Hf}, \mathrm{Sc} / \mathrm{Zr}$; Dean et al., 2002; Croudace et al, 2006; Cuven et al., 2010; Ratcliffe et al., 2006); (iii) provenance indicators (Ni/Al, $\mathrm{Cr} / \mathrm{Al}, \mathrm{Th} / \mathrm{Sc}, \mathrm{Ti} / \mathrm{Zr}, \mathrm{MgO} / \mathrm{Al}_{2} \mathrm{O}_{3}, \mathrm{Ti} / \mathrm{Nb}$; Amarosi et al., 2007; Dinelli et al., 2007); and (iv) mineralogical indicators $\left(\mathrm{P}_{2} \mathrm{O}_{5} / \mathrm{Al}_{2} \mathrm{O}_{3}, \mathrm{Cr} / \mathrm{Nb}, \mathrm{Lu} / \mathrm{Zr}, \mathrm{Cr} / \mathrm{Zr}\right.$; Bhatia \& Crook, 1986; Morton \& Hallsworth, 1994; Cingolani et al., 2003; Ratcliffe et al., 2004, 2006; Wright et al., 2010; Clift et al., 2014). Some elements used, such as Fe, S, U and P, are redox-sensitive and palaeoproductivity indicators. However, in this study, these elements were analyzed in the context of mineralogical and hydrothermal indicators only.

By utilizing these geochemical proxies, this paper outlines correlative chemostratigraphic packages, herein referred to as chemofacies, within the Montney Formation and ties them to well logs. Additionally, conodont analyses published by Golding et al. (2014) and Orchard \& Tozer (1997), on outcrop and one of the wells used in this study, anchor the geochemical data set of the current study to the existing regional biostratigraphic framework. The identification and correlation of these geochemically distinct packages reveals regional clinoform surfaces within the Montney Formation and 
provides an initial template for developing regionally consistent stratigraphic and palaeogeographic models for other fine-grained successions. Elemental correlations, analyzed through Pearson product-moment correlation analysis (PPMC) and eigenvector analysis (EA), support mineralogical data obtained using X-ray diffraction (XRD). When combined with geochemical proxies for provenance, mineralogy, clay and detrital input, these observations highlight trends in sediment sourcing, relative sea-level, climatic effects and identify intervals of inferred hydrothermal input to the basin.

\section{GEOLOGICAL SETTING}

Within the Western Canada Sedimentary Basin (WCSB), the earliest Triassic deposits in the subsurface are assigned to the Montney Formation. The Montney Formation was deposited on the western margin of Pangaea (eastern Panthalassa margin) and is thickest in the area of the Peace River Embayment (the Peace River Basin) (Fig. 1; Davies et al., 1997). The Peace River Embayment is a broad structural basin formed during the Carboniferous as a result of the collapse of the Peace River Arch, a structural Precambrian high that remained emergent until the end of the Devonian (Richards et al., 1994; Davies et al., 1997; Moslow \& Davies, 1997). During the early Triassic, western Canada was rotated approximately $30^{\circ}$ clockwise from its current orientation, with the regional shoreline trend approximately parallel to the axis of the modern Rocky Mountains (Golonka et. al., 1994; Davies, 1997; Golonka \& Ford, 2000).

The Montney Formation is ca $300 \mathrm{~m}$ thick, and extends over $150,000 \mathrm{~km}^{2}$ of northeastern British Columbia and west-central Alberta (Edwards et al., 1994). It consists of siltstone, sandstone and coquina deposited in environments that range from shoreface to 
distal offshore, including turbidites (Davies et al., 1997; Moslow \& Davies, 1997; Dixon, 2000; Moslow, 2000; Utting et al., 2005; Hays et al., 2007; Zonneveld et al., 2010a). Within the study area, the Montney Formation is unconformably overlain by the Doig Formation and unconformably underlain by the Belloy Formation.

Previous stratigraphic analyses of the Montney Formation have focused on traditional core and well log correlations supported by limited biostratigraphic (conodont) data (Zonneveld et al., 2007; Beatty et al., 2008; Zonneveld et al., 2010a,b; MacNaughton \& Zonneveld, 2010; Golding et al., 2014; Sanei et al., 2015; Wood et al., 2015). Temporal constraints on Montney deposition are limited to biostratigraphic analyses in outcrop and subsurface and demonstrate deposition occurred from the start of the Triassic (250 Mya) to the Anisian (247 Mya; e.g. Tozer, 1994; Paull et al., 1997; Utting et al., 2005; Orchard \& Zonneveld, 2009; Zonneveld et al., 2010a; Golding et al., 2014). Although palynomorphs, bivalves and ammonoids have proven useful in some studies (e.g. Tozer, 1994; Utting et al., 2005), conodont biostratigraphy is the most effective, provided sufficient material is available to produce diagnostic elements (Paull et al., 1997; Orchard \& Zonneveld, 2009; Golding et al., 2014). To this end, the key well used for this study (UWI 16-17-083-25W6; full core) has been lithologically described and dated using conodont analysis (Golding et al., 2014).

\section{METHODS}

A total of 641 samples were analyzed and include core samples (wells c-74-G/94-b-09, d-48A/94-b-09, 2-30-070-24W5, 16-17-083-25W6 and 11-20-082-02W6) and outcrop samples (Ursula Creek, British Columbia; Fig. 1). The wells and outcrop were chosen to create a 
transect perpendicular to the Triassic palaeoshoreline. Samples from these locations were analyzed using Thermo Scientific XSERIES 2 ICP-MS and iCAP 7000 Series ICP-OES (Thermo Fisher Scientific, Waltham, MA, USA) at Chemostrat and a Perkin Elmer ICP-MS and Spectro ICP-OES (Perkin Elmer, Waltham, MA, USA) at Bureau Veritas Mineral Laboratories. Additionally, one data set, 2-30-070-24W5, was analyzed using a Bruker AXS D8 Advance Diffractometer (Bruker, Billerica, MA, USA) at SGS Mineral Services in Lakefield, Ontario.

A statistical evaluation of the correlation between mineralogical and elemental data was conducted using PPMC and EA on DataDesk ${ }^{\circledR}$ 6.3.1 (Data Description Inc., Ithaca, NY, USA). Additionally, chemostratigraphic packages were defined using principle component analysis and cluster analysis on the most complete core data set (16-17-083-25W6), which was used as the type section. In total, 84 variables were considered (Table 1). The variables used fall into eight categories: (1) oxides, (2) unaltered trace element data provided by the analytical laboratories, (3) oxide elements, with the calculated elemental portion of the oxides converted to ppm, and (4) to (8) indicators, comprised of ratios of elements or oxides.

Chemofacies were then analyzed and summarized using clay indicator ratios $(\mathrm{Cr} / \mathrm{Sc}$, $\left.\mathrm{Zr} / \mathrm{La}, \mathrm{Zn} / \mathrm{Sc}, \mathrm{SiO}_{2} / \mathrm{Al}_{2} \mathrm{O}_{3}, \mathrm{Ga} / \mathrm{Rb}, \mathrm{K}_{2} \mathrm{O} / \mathrm{Al}_{2} \mathrm{O}_{3}, \mathrm{~K}_{2} \mathrm{O} / \mathrm{Rb}, \mathrm{Na}_{2} \mathrm{O} / \mathrm{Al}_{2} \mathrm{O}_{3}, \mathrm{Rb} / \mathrm{Al}\right)$, provenance indicator ratios ( $\mathrm{Ni} / \mathrm{Al}, \mathrm{Cr} / \mathrm{Al}, \mathrm{Th} / \mathrm{Sc}, \mathrm{Ti} / \mathrm{Zr}, \mathrm{MgO} / \mathrm{Al}_{2} \mathrm{O}_{3}, \mathrm{Ti} / \mathrm{Nb}$ ), detrital input indicators $\left(\mathrm{TiO}_{2} / \mathrm{Al}_{2} \mathrm{O}_{3}, \mathrm{TiO}_{2} / \mathrm{K}_{2} \mathrm{O}, \mathrm{Lu} / \mathrm{Hf}, \mathrm{Sc} / \mathrm{Zr}\right)$ and mineralogical indicators $\left(\mathrm{P}_{2} \mathrm{O}_{5} / \mathrm{Al}_{2} \mathrm{O}_{3}, \mathrm{Cr} / \mathrm{Nb}, \mathrm{Lu} / \mathrm{Zr}\right.$, $\mathrm{Cr} / \mathrm{Zr}$ ). An average value of each ratio was determined from the type section. These overall average values were compared to the averaged values generated from within each chemofacies in order to make broad interpretations. Due to the low elemental immobility, and the relation to detrital input, subsequent data sets were correlated primarily using the 
signatures of Sc/Zr, Lu/Hf, and Zr/La (see the Elemental Indicators section below for a more detailed explanation of the ratios used in this study). For a detailed methodology, refer to the supplementary information.

\section{Elemental Indicators}

\section{Clay indicators}

Some elemental ratios, for example $\mathrm{Ga} / \mathrm{Rb}$, are interpreted to reflect the proportion of kaolinite to illite (Ratcliffe et al., 2010, 2015; Hofer et al., 2013) because kaolinite is a major carrier of Ga (Wang et al., 2011; Dai et al., 2012a). Although K/Rb can reflect weathered versus volcanoclastic input (Plank \& Langmuir, 1998), when compared to the ratio $\mathrm{K}_{2} \mathrm{O} / \mathrm{Al}_{2} \mathrm{O}_{3} ; \mathrm{K} / \mathrm{Rb}$ can also indicate high illite content (i.e. low values of $\mathrm{K} / \mathrm{Rb}$ paired with high $\mathrm{K}_{2} \mathrm{O} / \mathrm{Al}_{2} \mathrm{O}_{3}$ indicate high illite content; Ratcliffe et al., 2006, 2015; Hofmann et al., 2001; Hofer et al., 2013). Additionally, high $\mathrm{Rb} / \mathrm{Al}_{2} \mathrm{O}_{3}$ ratio values indicate high proportions of illite and mica with little kaolinite (Pearce et al., 2005). The ratio of $\mathrm{Na} / \mathrm{Al}$ can act as a proxy for smectite content (Hofmann et al., 2001; Hofer et al., 2013). Chromium is associated with chlorite while Sc is associated with kaolinite (Ratcliffe et al., 2015). In general, Sc and Ga are observed to correlate with light rare earth elements (LREE) and Al in kaolinite, although Ga has been observed to adsorb onto illite and montmorillonite under certain $\mathrm{pH}$ conditions and can be associated with Cr-spinels (Esser et al., 1991;Paktunc \& Cabri, 1995; Takahashi et al., 1999; Hofmann, 2003; Tyler, 2004; Dai et al., 2006, 2008, 2012a,b; Pearce et al., 2010; Wang, 2011; Benedicto et al., 2014). The ratio of Zr/La can indicate clay and mica content as Zr is often associated with heavy minerals such as garnet and zircon, while La is often bound in the clay and mica fraction (Plank \& Langmuir, 1998; Preston et al., 1998; Pearce et al., 1999, 2010). For example, ratios such as Zr/La can be used to assess for elemental dilution 
(Preston et al., 1998). Pearce et al. (1999) discussed the need to account for elemental dilutions due to elements of a more detrital nature (for example, Si and Al) being 'diluted' in zones that have been highly cemented by carbonate. By comparing the $\mathrm{Zr} / \mathrm{La}$ ratio to geochemical proxies for carbonate input (such as $\mathrm{Ca}$, $\mathrm{Sr}$ and $\mathrm{Mg}$ ), the dilution effect can be investigated. Because illite fixes Zn much more readily into its structure than kaolinite (Reddy \& Perkins, 1973) and Sc (along with Ga) is often sequestered with other REE and Al into kaolinite (Esser et al., 1991; Paktunc \& Cabri, 1995; Takahashi et al., 1999; Hofmann, 2003; Tyler, 2004; Dai et al., 2006, 2008, 2012a a,b; Pearce et al., 2010; Wang, 2011; Benedicto et al., 2014 ), the ratio of $\mathrm{Zn} / \mathrm{Sc}$, in the context of other clay proxies, can be used to determine illite/kaolinite proportions (Pearce et al., 1999). Similarly, the $\mathrm{TiO}_{2} / \mathrm{K}_{2} \mathrm{O}$ ratio is representative of the amount of anatase relative to illite (Ratcliffe et al., 2006).

\section{Detrital indicators}

Perhaps the most commonly used; the $\mathrm{TiO}_{2} / \mathrm{Al}_{2} \mathrm{O}_{3}$ ratio can indicate specific sediment flux, in this case aeolian input and also detrital flux associated with relative sea-level change (Chen et al., 2013). Additionally, sediment recycling concentrates heavy minerals, especially zircon, in the sediment, allowing for ratios such as Sc/Zr to be used to indicate the relative intensity of sediment recycling (McLennon et al., 1993; Mongelli et al., 2006). Likewise, the ratio of $\mathrm{Lu} / \mathrm{Hf}$, because of the higher concentration of $\mathrm{Hf}$ in zircons, can indicate continental shelf versus pelagic clay deposits (Patchett et al., 1984; Plank \& Langmuir, 1998). Because the mineralogical products of weathering are often higher in $\mathrm{K}$ content, while Ti content largely remains unchanged during weathering, the ratio of $\mathrm{TiO}_{2} / \mathrm{K}_{2} \mathrm{O}$ can be used to determine the relative input of weathered material into the basin over time (Wei et al., 2003).

This article is protected by copyright. All rights reserved. 


\section{Provenance indicators}

Ratios, such as $\mathrm{Cr} / \mathrm{Al}$ and $\mathrm{Ni} / \mathrm{Al}$, are uninfluenced by grain-size changes (Dinelli et al., 2007). Because $\mathrm{Cr}$ can be associated with both heavy minerals and clays (Meinhold et al., 2007), the ratio $\mathrm{Cr} / \mathrm{Al}$ can indicate $\mathrm{Cr}$ enrichment associated with heavy minerals sourced from igneous rocks (Preston et al., 1998; Ratcliffe et al., 2004; Wright et al., 2010). Likewise, an excess of $\mathrm{Ni}$ relative to $\mathrm{Al}$ can indicate ultramafic provenance (Amarosi et al., 2007). Zirconium/Niobium has been demonstrated to indicate ultramafic igneous input, with $\mathrm{Nb}$ being associated with Nb-rich rutile (Ratcliffe et al., 2006). High values of Th/Sc are interpreted as resulting from felsic sediment components, with $\mathrm{Th} / \mathrm{Sc}$ having been used as a measure of the degree of igneous differentiation (McLennan et al., 1990, 1993; Hofmann et al., 2003; López de Luchi et al., 2003; Bracciali et al., 2007). The ratio Mg/Al (normalized to account for grain-size variation), can indicate ultramafic input or dolomite when associated with Ca (Amarosi et al., 2007; Dinelli et al., 2007). This ratio has also been demonstrated to indicate Mg-rich clay (e.g., palygordkite) input in deposits related to the Negev loess (Israel et al., 2015). Additionally, Ti/Nb has been demonstrated to indicate igneous input and has been linked to intraplate settings with basaltic volcanism (Bonjour and Dabard, 1991). The ratio of $\mathrm{Ti} / \mathrm{Zr}$ has been demonstrated to distinguish turbidites from various tectonic sources and can (when plotted against La/Sc) reveal the tectonic setting of the sediment (Bhatia \& Crook, 1986; Cingolani et al., 2003).

\section{Mineralogical indicators}

In terms of trace element abundance, $\mathrm{Ti}, \mathrm{Nb}$ and $\mathrm{Ta}$ are related to the presence of heavy minerals (foremost rutile, but also anatase, illmenite and leucoxene; Pearce et al., 2010). Niobium is associated with $\mathrm{Ti}$ in rutile (Preston et al., 1998) and therefore the $\mathrm{TiO}_{2} / \mathrm{Nb}$ ratio 
can be used to account for rutile-associated $\mathrm{Nb}$. Iron has been linked to the presence of Feoxyhydroxides (for example, goethite), pyrite and/or ferroan dolomite (Pearce et al., 2010). Calcium, Mg, Mn and Sr are generally associated with carbonate minerals (for example, calcite, dolomite and siderite; Pearce et al., 2010). In addition to feldspar, Na can be present in the clay fraction as well as in halite (Pearce et al., 2005, 2010). The concentration of $\mathrm{K}, \mathrm{Rb}$ and Cs are primarily controlled by the amount of illite and mica present (Pearce et al., 2010). The deposition of $\mathrm{P}$ in sediments is related to multiple factors including palaeoproductivity and hydrothermal flux (Feely et al. 1994; Wheat et al. 1996; Tribovillard et al., 2006). Because of the co-occurrence with organic matter, phosphorous is often present in association with clays and can indicate the presence of biogenic phosphatic fish remains and calcareous microfossils (Pearce et al., 2010). When present with Fe, Mn, and REE, the presence of $P$ has been linked to siderite (Pearce et al., 2010). Substitutions within apatite include $\mathrm{Y}$ and REE for Ca, with Sr balancing the remaining charge (Preston et al., 1998). Chromium (III) occurs within spinel, often substituting for Al (III) or Fe (III) (Preston et al., 1998). Chromium-spinel is found in primitive basic igneous rocks and ultrabasic igneous rocks (Preston et al., 1998). The similar ionic radii of $\mathrm{Nb}$ and $\mathrm{Ti}$ allows the former to substitute into the crystal lattice of Ti-bearing minerals such as illmenite and rutile; however Nb-rich rutile is generally restricted to ultramafic, alkaline, igneous rocks (Preston et al., 1998). Therefore, the ratio of $\mathrm{Cr} / \mathrm{Nb}$ can be used to estimate the abundance of Ti-oxide heavy minerals, and is thought to reflect variation in the abundance of Ti-oxide heavy minerals with respect to spinel (Ratcliffe et al., 2015). The ratio of Lu/Zr is closely related to the garnet-zircon index (GZi index) and reflects the proportion of garnet to zircon (Wright et al., 2010). The GZi index has been used to fingerprint unique heavy mineral populations related to different sandstone types, which reflect overall lithological differences (Morton \& 
Yaxely, 2007). Likewise, $\mathrm{Cr} / \mathrm{Zr}$ is a proxy for the chrome spinel-ziron index (CZI index), which is another provenance-sensitive ratio (Morton \& Hallsworth, 1994; Ratcliffe et al., 2006; Morton \& Yaxely, 2007; Wright et al. 2010).

\section{RESULTS AND INTERPRETATIONS BY CATEGORY}

\section{Chemofacies Descriptions}

Results

Thirteen chemofacies were recognized based on differences in the abundances of major oxides, trace elements and elemental ratios. Twelve packages were first identified and defined in the most complete sample set (16-17-083-25W6; Figs 2 to 5) using cluster and principal component analyses; although only occurring in the basal data point (and thus statistically insignificant), a thirteenth division was added based on the published contact between the Permian Belloy Formation and the Montney Formation in this data set (Golding et al., 2014). Chemofacies are herein defined as distinct bodies of rock characterized by a particular combination of stable isotopic signatures, oxide elemental patterns, trace element signatures, or element ratios dependent on underlying mineralogical controls and organic matter that distinguish it from surrounding strata. The chemofacies identified in this study are labelled in stratigraphic order, beginning at the base. Numerical values for each chemical ratio were averaged for the entire 16-17-083-25W6 data set; this average was compared to the calculated average value for each chemofacies in Tables 5 to 8 .

This article is protected by copyright. All rights reserved. 
Interpretation

Average values displayed in Tables 5 to 8 were used to guide the interpretation of each chemofacies, which are listed in Table 9. These interpretations highlight perceived changes in clay content throughout the sample set. Namely, chemofacies 1 to 5 show high clay input, with low smectite and kaolinite content and greater amounts of illite (Fig. 4). Within chemofacies 5 , there is a shift to high smectite content, and, by chemofacies 7 , a switch from generally high to low clay content. Additionally, illite is replaced by kaolinite and smectite as the more abundant clay phases. Chlorite appears in higher than average proportions in chemofacies 1 (Belloy Formation) and chemofacies 13 (Doig Formation).

\section{Chemostratigraphic correlation}

Results

Correlation between wells reveals the presence of various chemofacies within each well or outcrop sample set. Data sets were correlated with the type well using proxy ratios for detrital flux (Sc/Zr and Lu/Hf) and clay input ( $\mathrm{Zr} / \mathrm{La})$, which should not be affected by fluctuations in redox conditions or diagenesis. Detailed correlation of each data set is visible in Figs S1 to S20; additional supplementary figures illustrate points of correlation between the type data set and each additional well (Figs S21 to S25), as well as lithologs for four data sets (Figs S26 to S29).

\section{Interpretation}

Data from Ursula Creek were found to correspond with all 13 defined chemofacies (Fig. 6). Wells d-48-A/94-B-9 and c-74-G/94-B-9 were found to contain chemofacies 8, 9, 10 and a small portion of 11 . This suggests that an unconformity is present, with erosion having 
removed most of chemofacies 11 , and all of chemofacies 12. Data from well 11-20-82-2W6 was found to correspond to chemofacies 2 and 3. Well 2-30-70-24W5 was interpreted to correspond to chemofacies 1, 2, 3, 7 and 8. Both Wells 11-20-82-2W6 and 2-30-70-24W5 are missing chemofacies 9 to 12, which suggests erosion, and have thicker lower chemofacies. Thicker lower chemofacies in the eastern data sets (wells 11-20-82-2W6 and 2-30-70-24W5) suggests clinoform deposition from the east.

Correlatable conodont intervals, as previously described by Golding et al. (2014) and Orchard \& Tozer (1997), occur in chemofacies 7 (well 16-17-083-25W6 and Ursula Creek; Fig. 6). The precise horizons from which the conodont samples were obtained are indicated on the sections identified herein. These samples provide a means of calibrating the chemofacies with the global integrated ammonoid-conodont biostratigraphic zonation, which is based in large part on the British Columbia Triassic succession (Tozer, 1994; Orchard \& Tozer, 1997; Orchard \& Zonneveld, 2009; Golding et al., 2014). Additionally, P/Fe data from wells 16-17-083-25W6, d-48-A/94-B-9, c-74-G/94-B-9, and the outcrop Ursula Creek all indicate high $\mathrm{P} /$ Fe within chemofacies 7 and 8, which supports the interpreted correlations.

\section{Elemental associations and mineralogy}

Results

The PPMC for each oxide and element was calculated to determine mineralogical associations for each core and the Ursula Creek outcrop (Table 2 and S1 to S6). Values exceeding \pm 0.8 were considered to represent strong positive or negative correlations, where a value of \pm 1 implies perfect positive or negative correlation (Deutsch, 2002). Elements that have a high correlation with each other include; $\mathrm{SiO}_{2}, \mathrm{Al}_{2} \mathrm{O}_{3}, \mathrm{TiO}_{2}$ and $\mathrm{K}_{2} \mathrm{O}$ (referred to as the 
silicate oxides). $\mathrm{CaO}$ correlates negatively with the $\mathrm{SiO}_{2}$ and positively with $\mathrm{MnO}$ and $\mathrm{MgO}$. Of note, $\mathrm{Th}, \mathrm{Ta}, \mathrm{Nb}, \mathrm{Rb}, \mathrm{Ga}$ and $\mathrm{Sc}$ share a high PPMC with the $\mathrm{SiO}_{2}$, and negatively correlate with $\mathrm{CaO}$. Nickel and Barium also correlate positively with $\mathrm{K}_{2} \mathrm{O}$. $\mathrm{Hf}$ correlates well with $\mathrm{Na}_{2} \mathrm{O}$ and Zr. As would be expected, the REE correlate strongly with one another.

Bulk results of the XRD analysis (detection limit: 0.5 to $2.0 \%$ ) reveals the presence of quartz (42 to $71 \%$ ), dolomite ( 3 to $20 \%$ ), microcline (4 to $15 \%$ ), muscovite ( 2 to $16 \%$ ), albite ( 2 to $9 \%$ ), diopside ( 1 to $4 \%$ ) and accessory minerals (Table 4). Accessory minerals include; pyrite, clinochlore, calcite, ankerite, kaolinite, chlorapatite, fluorapatite, brookite, siderite and magnesian calcite. Within the XRD sample set quartz is consistently the most abundant mineral, followed by dolomite.

Principal component analyses were conducted on all data sets and plots of eigenvector one versus two were produced (Fig. 7). Four major, consistent elemental clusters are observed within the plot series. A cluster of elements, termed the heavy element cluster, occurs in the centre and includes $\mathrm{Mo}, \mathrm{Zn}, \mathrm{V}, \mathrm{W}, \mathrm{Ni}$ and $\mathrm{Cr}$. The REE and $\mathrm{Y}$ occur together in all plots and are referred to as the $\mathrm{REE}+\mathrm{Y}$ cluster. $\mathrm{K}_{2} \mathrm{O}, \mathrm{Rb}, \mathrm{Al}_{2} \mathrm{O}_{3}, \mathrm{Nb}, \mathrm{TiO}_{2}$, $\mathrm{Ga}, \mathrm{Ta}, \mathrm{Cs}, \mathrm{Be}$ and $\mathrm{Sc}$ also occur in close association and comprise the $\mathrm{Al}_{2} \mathrm{O}_{3}$ cluster. $\mathrm{MnO}$, $\mathrm{MgO}$, and $\mathrm{CaO}$ generally plot very closely together and are defined as the $\mathrm{MgO}$ group. Interestingly, in well c-74-G/94-B-9, $\mathrm{CaO}$ occurs in a cluster with $\mathrm{Sr}, \mathrm{P}_{2} \mathrm{O}_{5}$ and $\mathrm{U}$, separate from $\mathrm{MgO}$ and $\mathrm{MnO}$ (Fig. 7F). $\mathrm{Na}_{2} \mathrm{O}$ occurs apart from major clusters, and is associated with various other elements ( $\mathrm{Cr}, \mathrm{Cu}, \mathrm{Sn}, \mathrm{Be}, \mathrm{Zn}, \mathrm{Co}, \mathrm{Ni}$ and $\mathrm{Pb})$. $\mathrm{TiO}_{2}$ clusters with $\mathrm{Nb}$ in all plots. Chromium is observed to occur in association with varying elements ( $\mathrm{Ni}, \mathrm{Sr}, \mathrm{Ce}$ and $\mathrm{Co}$ ) but is often isolated from the major clusters (Fig. 7D). Zirconium occurs in close proximity to Hf in all plots. $\mathrm{SiO}_{2}$ occurs in isolation in the plots for wells $11-20-082-02 \mathrm{~W} 6$ and 2-30-07024W5. In the remaining wells and outcrop, $\mathrm{SiO}_{2}$ occurs in association with the $\mathrm{Al}_{2} \mathrm{O}_{3}$ cluster. 
$\mathrm{Fe}_{2} \mathrm{O}_{3}$ plots with $\mathrm{S}$ in the plots for Ursula Creek and wells 16-17-083-25W6, d-48-A/94-B-9, and c-74-G/94-B-9. These two elements are closely associated in well 11-20-082-2W6, and plot near the $\mathrm{Al}_{2} \mathrm{O}_{3}$ cluster. Strontium is often closely associated with $\mathrm{CaO}$ (Fig. 7A, C, D and F).

Interpretation

Principal component analysis has been an integral tool for assessing the mineralogy in a number of chemostratigraphic studies (e.g. Pearce et al. 2005; Pearce et al., 2010). Mineral affinities identified by this method (Pearce et al., 2010) are presented in Table 3. The close proximity of $\mathrm{Hf}$ and $\mathrm{Zr}$ in the eigenvector plot suggests the presence of zircon despite the apparent lack of zircon in XRD analyses. Hafnium, $\mathrm{Zr}$ and $\mathrm{Cr}$ are also associated with $\mathrm{Cr}$ spinel; however, this phase was also not identified in the XRD data. It is possible that both zircon and $\mathrm{Cr}$-spinel phases are present but at levels below the detection limit for XRD. The co-occurrence of $\mathrm{TiO}_{2}, \mathrm{Nb}, \mathrm{Ta}$ and $\mathrm{Th}$ is explained by the presence of rutile, detected during XRD analysis. The proximity of $U$ and REE to $\mathrm{P}_{2} \mathrm{O}_{5}$ suggests scavenging of these elements by phosphatic debris. This is consistent with the identification of both fluorapatite and calcium phosphate in XRD analysis.

$\mathrm{Al}_{2} \mathrm{O}_{3}$ and $\mathrm{Ga}$ are associated with kaolinite, while the close proximity of $\mathrm{K}_{2} \mathrm{O}, \mathrm{Rb}$, and $\mathrm{Cs}$ is accounted for by the presence of illite/smectite. Given that $\mathrm{K}_{2} \mathrm{O}$ plots much closer to $\mathrm{SiO}_{2}$ than to $\mathrm{Rb}$ and $\mathrm{Cs}$, it is likely that $\mathrm{K}$-feldspar is present in a higher concentration than these clays. This interpretation is supported by the XRD data, which shows high concentrations of microcline (Table 4).

This article is protected by copyright. All rights reserved. 
The association of $\mathrm{MnO}$ and $\mathrm{MgO}$ is explained by the presence of dolomite, which is consistent with the XRD results. $\mathrm{CaO}$ plots slightly away from both $\mathrm{MnO}$ and $\mathrm{MgO}$, suggesting the presence of minor calcite cement. Indeed, calcite, as a distinct phase, occurred only in minor amounts in samples analyzed by XRD.

\section{Provenance}

Results

Plotting La/Sm versus Yb/Sm (after Plank \& Langmuir, 1998; Fig. 8) reveals a similar trend between the sample sets of 16-17-083-25W6 and Ursula Creek. A strong linear trend is visible, overprinted by a data cluster near the origin. Data points with the highest values of $\mathrm{La} / \mathrm{Sm}$ and $\mathrm{Yb} / \mathrm{Sm}$ occur in chemostratigraphic interval 8. Data from well 2-30-070-24W5 exhibit a clustering trend similar to that seen in 16-17-083-25w6, with a slight vertical spread. Data points from well 11-20-082-02W6 are consistently moderate in La/Sm and $\mathrm{Yb} / \mathrm{Sm}$ values, and no linear trend is apparent. As observed in the data from 16-17-08325W6 and Ursula Creek, data for wells d-48-A/94-B9 and c-74-G/94-B-9 display a central cluster and a positive, linear trend.

Plots of Th/Sc (felsic) versus Cr/Th (mafic) after Bracciali et al., (2007) are shown in Figs 9 and 10 and reveal a near vertical trend in all data sets with low values of $\mathrm{Cr} / \mathrm{Th}$. Data points from the Belloy Formation (Chemofacies 1) exhibit high $\mathrm{Cr} / \mathrm{Th}$ and low $\mathrm{Th} / \mathrm{Sc}$ values. Samples from the Doig Formation (Chemofacies 13) occur as a spread of points between the main linear trend and the Belloy outliers. Samples from chemostratigraphic interval 8 plot in an arc between the main linear trend and Doig Formation data points. Generally, stratigraphically older Montney data points plot closer to the origin, with increasing Th/Sc content associated with stratigraphically younger points. 
Interpretation

Plotting $\mathrm{La} / \mathrm{Sm}$ versus $\mathrm{Yb} / \mathrm{Sm}$ can help differentiate continental, hydrothermal and volcanic arc sediment sources (Plank \& Langmuir, 1998). Most data (from all sample sets) plot within the zone of continental detritus and clay scavenging. The exceptions to this are high La/Sm and $\mathrm{Yb} / \mathrm{Sm}$ data points associated with the sample sets from 16-17-083-25W6 and Ursula Creek, which suggest hydrothermal input. These hydrothermally influenced samples occur within chemofacies 8, and, when compared to the work of Golding et al. (2014), are Spathian in age.

Upper crustal (felsic) and mantle (mafic and ultramafic) sources of sediments contain unique geochemical signatures expressed in the Th, Sc and $\mathrm{Cr}$ content. Felsic sources are indicated by high Th/Sc and low $\mathrm{Cr} / \mathrm{Th}$ signatures, while mafic and ultramafic sources have characteristic high $\mathrm{Cr} / \mathrm{Th}$ and low Th/Sc values (Bracciali et al., 2007). The increase in felsic content in stratigraphically younger samples suggests a gradual change in sediment source over time. This could be attributed to a gradual change in riverine output/sourcing (possibly related to climate and weathering) or could represent the introduction of a completely new sediment source (such as an approaching terrane). The approach of a new terrane is entirely feasible as terrane accretion is thought to have begun by the Early-Middle Triassic (Beranek \& Mortensen, 2011).

\section{Biogenic versus abiotic carbonate}

Results

The data plots of Sr versus Mg (Fig. 11) reveal a low angle, positive linear trend with Sr levels generally remaining below 400 ppm. A high-Sr, low-Mg outlier (16-17-083-25W6), indicating Sr levels of over 700 ppm, corresponds to a depth of $2440.2 \mathrm{~m}$. Scatter in the Sr values

This article is protected by copyright. All rights reserved. 
appear related to the low-Mg samples (<30000 ppm Mg). Scatter in Mg values occurs in the samples of high-Mg content (30000 to $60000 \mathrm{ppm} \mathrm{Mg).} \mathrm{These} \mathrm{values} \mathrm{follow} \mathrm{the} \mathrm{abiotic}$ trend of values published by Carpenter \& Lohmann (1992).

\section{Interpretation}

Non-skeletal, calcite cements have been shown to contain significantly less Sr than biotic marine calcite (Carpenter \& Lohmann, 1992). When Sr-Mg trends are compared, biotic calcite values can be up to five orders of magnitude higher than abiotic calcite, offset by ca 1250 ppm (Carpenter \& Lohmann, 1992). Biotic calcite trends between low values ( $\mathrm{Sr}=1400$ and $\mathrm{Mg}=2000)$ and high values $(\mathrm{Sr}=2600$ and $\mathrm{Mg}=56000)$, while abiotic calcite trends between Sr/Mg of 300/10000 and 1300/50000; abiotic calcite exhibits significantly lower Sr values (Carpenter \& Lohmann, 1992).

With the understanding that abiotic calcite is the predominant phase, zones of calcite cement were interpreted to be present where positive excursions in $\mathrm{CaO}$ and $\mathrm{Sr}$ occurred in association with low concentrations of $\mathrm{MgO}, \mathrm{MnO}, \mathrm{SiO}_{2}, \mathrm{Al}_{2} \mathrm{O}_{3}$ and $\mathrm{TiO}_{2}$ (Fig. 12). Strontium can be associated with minerals such as gypsum, anhydrite, strontianite and celestite, in addition to calcite and aragonite (Banner, 1995). Data from wells examined here demonstrate a close correlation between $\mathrm{CaO}$ and $\mathrm{Sr}$ in the principal component analysis. Furthermore, XRD analysis did not identify the presence of gypsum, anhydrite, strontianite, or celestite, thus supporting the interpretation that calcite is the principal Sr-bearing mineral. Within well 16-17-083-25W6, zones of calcite cement occur within chemofacies 5, 7 and 11; the highest frequency of calcite occurrence is within chemofacies 7.

Calcite is probably a cement phase as evidenced by the $\mathrm{Sr}-\mathrm{Mg}$ plot (Fig. 11). The data in this study clearly trends along the abiotic vector, with Sr values well below 1000 ppm (cf. 
Carpenter \& Lohmann 1992). The outlier with the highest Sr content (over $700 \mathrm{ppm}$ ) is from an interval identified as having been sourced from high sediment recycling (Fig. 2). Therefore, the high Sr values in this sample may reflect increased weathering input (PettRidge et al., 2009).

Dolomite-rich horizons were identified as having high $\mathrm{CaO}$ content and being enriched in $\mathrm{MgO}$ and $\mathrm{MnO}$. The presence of $\mathrm{MnO}$ within dolomite has been confirmed in cathodoluminescence studies of dolomite (e.g. Pierson, 1981). Dolomite-rich horizons were observed within the majority of chemofacies for well 16-17-083-25W6, with the notable exceptions being chemofacies 4 and a large portion of chemofacies 10 and 11 .

\section{Hydrothermal Indicators and iron mineral phase changes}

Results

Using the data set from well 16-17-083-25W6, a depth plot of P/Fe (Fig. 13) reveals low values overall, below 0.1. Positive excursions in this ratio occur mid-section and also near the top of the section. The two intervals with the highest $\mathrm{P} / \mathrm{Fe}$ values occur at a depth of $2375 \mathrm{~m}$ (values approaching 1) corresponding to chemofacies 8, and within the Doig Formation above $2260 \mathrm{~m}$ depth, where values reach as high as 8 . The Ursula Creek data set also exhibits values within the range of those observed in the key data set, 16-17-083-25W6; specifically high values are observed in chemofacies 7 and 8 (Fig. 14). Samples from wells d48-A/94-b-9, c-74 g-94-B-9, and 2-30-070-24W5 also exhibit similar P/Fe value ranges for chemofacies 7, 8 and 13 (the Doig Formation). Well 11-20-82-2W6 shows consistently high $\mathrm{P} /$ Fe values evident in chemofacies 4,5 and 6 .

To further investigate possible hydrothermal effects, chondrite-normalized plots of REE were constructed for all depths within the most complete sample set (UWI 16-17-083- 
25W6). This reveals severe middle rare earth element (MREE) depletion at depths of 2367.6 $\mathrm{m}$ and $2368 \mathrm{~m}$ (Figs 13 and 15). At these intervals, values of $\mathrm{Nd}, \mathrm{Sm}, \mathrm{Eu}, \mathrm{Gd}, \mathrm{Tb}, \mathrm{Dy}, \mathrm{Ho}$ and Er plot well below the values observed in surrounding intervals (Fig. 15). A depth plot of Fe/S (Fig. 13) from the type well 16-17-083-25w6 reveals relatively low ratio values (averaging 20) in samples below 2400 m depth. Negative excursions to values below 5 occur at 2401 and $2440 \mathrm{~m}$ depth. Above $2400 \mathrm{~m}$, the ratio value increases to over 60 , remaining high until $2260 \mathrm{~m}$ depth. Iron/sulphur values return to low levels (averaging 20) at $2260 \mathrm{~m}$ depth.

\section{Interpretation}

The ratio of $\mathrm{P} / \mathrm{Fe}$ has been evaluated in hydrothermal deposits, with hydrothermal plume deposits yielding a P/Fe value of 0.12 to 0.23 (Feely et al., 1994; Wheat et al., 1996). Data sets located proximally to one another, from 16-17-083-25W6, Ursula Creek, c-74-G/94-B-9, and $d-48-A / 94-B-9$, show $P / F e$ values within chemofacies 7 and 8 that fall within the range identified for hydrothermal plumes (between 0.12 and 0.23 ) by Feely et al. (1994). High $\mathrm{P} /$ Fe values also occur in the Doig phosphate zone (chemofacies 13; Fig. 13), but REE plots within the Doig samples show no evidence for high temperature hydrothermal input. Therefore, this signature is interpreted here to represent the input of hydrothermal plume particles enriched in Fe. This would also explain the $\mathrm{P} / \mathrm{Fe}$ values observed within data sets 11-20-82-2w6 and 2-30-70-24W5.

Additionally, the molar ratio of Fe/S has been used to determine relative abundance of pyrite; ratio values near 2 signify the dominance of pyrite as the Fe-incorporating phase (Zhao \& Zheng, 2015). A change in this ratio can signify a change in Fe-bearing phase (such as Fe-hydroxide, which can be related to hydrothermal plumes). A depth profile for Fe/S 
within the key data set (16-17-083-25W6) shows that, at approximately $2400 \mathrm{~m}$, there is a switch in the relative abundance of pyrite as a major iron phase to Fe (III) oxyhydroxides and clays (Fig. 13). Increased Fe/S values of this phase occur near the phosphate excursion indicating the possibility of Fe (III) oxyhydroxide plume particles being deposited. Furthermore, the sample sets from 16-17-083-25W6, Ursula Creek, and d-48-A/94-B-9, show a strong signature of hydrothermal input as indicated by high $\mathrm{La} / \mathrm{Sm}$ and $\mathrm{Yb} / \mathrm{Sm}$ outliers (Plank \& Langmuir, 1998; Fig. 8). These hydrothermal signatures are associated with dolomitization in chemofacies 8.

\section{DISCUSSION}

\section{Hydrothermal Input and Implications}

The evidence of hydrothermal input co-occurring with dolomitization suggests that hydrothermal input to deeper water regions, possibly associated with basin margin faults, may have been a source of dolomitizing fluids in the Montney Formation. This would necessitate that hydrothermal input occurred post-depositionally. Chondrite-normalized plots for these samples indicate severe depletion of MREE (Fig. 15). A similar depletion was documented by Lev et al. (1999) and attributed to MREE sequestration by phosphate, then subsequent dissolution and a concomitant loss of $\mathrm{P}$ and MREE. Dissolution of phosphatic phases (such as apatite) may be promoted when sediments are exposed to hydrothermal fluids. However, evidence for high levels of hydrothermal plume activity complicates the timing of hydrothermal input. An alternative removal pathway for phosphate involves the adsorption onto Fe-Mn oxyhydroxides within hydrothermal plumes, resulting in transport to more distal environments (Wheat et al., 1996). This adsorption severely depletes the seawater phosphate concentrations surrounding the hydrothermal plume and high $\mathrm{P} / \mathrm{Fe}$ 
values, observed in this study's data set, can be considered to indicate hydrothermal Fe particle scavenging of $\mathrm{P}$ (Feely et al. 1994; Wheat et al. 1996). Hydrothermal plume inputs have also been suggested to explain high levels of trace elements, such as $\mathrm{Cu}$, in Cretaceous black shales (Brumsack, 2006). Such a mechanism would be consistent with the high levels of Cu observed in the present data in association with high $\mathrm{P} / \mathrm{Fe}$ and depleted MREE.

The timing of this hydrothermal flux is uncertain, although it does appear to coincide with the dolomitization identified in chemofacies 8 (Fig. 12). The involvement of hydrothermal fluids has two implications. First, there is the potential for trace element signatures to have been diagenetically altered proximal to this stratigraphic interval. However, hydrothermal alteration of underlying sediment appears to have been negligible owing to the presence of phosphatic lenses and nodules. The REE signature characteristic of the hydrothermally influenced interval indicates possible phosphate dissolution or scavenging by hydrothermal activity but it seems unlikely that the phosphate would be preserved at this lower stratigraphic interval if hydrothermal alteration had taken place. Second, hydrothermal fluids could also provide a mechanism for the observed dolomitization within the Montney Formation. This is significant as it has implications regarding the propagation of fractures, as dolomite and calcite contribute to the brittleness and hence the ability to generate fractures within a horizon compared to dominantly clayrich layers (Jin et al., 2015).

\section{Climate Change in the Early Triassic}

This article is protected by copyright. All rights reserved. 
This study demonstrates a marked shift in the nature of the clay component, as indicated by the geochemical proxies, as well as the average amount of clay over time (Fig. 4). There are marked changes in clay proportions, such as the change in abundance of illite to kaolinite and smectite, and the occurrence of chlorite. These transitions are of interest because they correspond to chronostratigraphic boundaries, namely the Permian/Triassic boundary, the Smithian/Spathian boundary, and the Early/Middle Triassic boundary (Fig. 16), all of which are important sequence stratigraphic boundaries in the Montney Formation (Zonneveld et al., in press).

Li et al. (2000) and Chaudhri \& Singh (2012) highlight the lithological and climatic drivers behind changes in clay content, although climate analysis using clay alone, should be interpreted with caution (Thiry, 2000). With regards to lithology, illite may be detrital, having been weathered from feldspars and micas, while chlorite is produced from the weathering of crystalline intermediate and basic, or low grade metamorphic rocks (Chaudhri \& Singh, 2012). Detrital illite is attributed to physical erosion being the predominant process within the hinterlands (Ruffell \& Batten, 1990; Ruffell et al., 2002a). In contrast, kaolinite forms from the weathering of basic and granitic sources (Chaudhri \& Singh, 2012). Additionally, as kaolinite is more prone to flocculation than other clays (e.g. Playter et al., 2017), the relative abundance of detrital kaolinite can indicate the relative source proximity (Ruffell et al., 2002a,b). The abundance of detrital kaolinite also increases with humid weathering (Chamley, 1989, Ruffell et al., 2002a,b). Smectite forms in seasonally dry and wet climates, although smectite and kaolinite can also be a product of volcanic ash deposition (Chamley, 1989, Li et al., 2000, Ruffell et al., 2002a,b). 
The high average values of illite, and higher overall clay component in the preSmithian/Spathian boundary samples here, suggest high rates of physical erosion. This is consistent with observations from Early Triassic (Griesbachian) deposits in China, where anomalously high sediment fluxes, with clay-rich compositions were observed (Algeo \& Twitchett, 2010). These high sedimentation rates have been hypothesized to be related to higher surface temperatures, increased acid rain and the loss of terrestrial ecosystems owing to the end-Permian Siberian Trap eruptions (Algeo \& Twitchett, 2010). The arid Pangean western coastline, where the Montney Formation was deposited, was probably characterized by rare perennial deltas and more numerous ephemeral fluvial sediment sources (Zonneveld \& Moslow, 2014; Zonneveld et al., in press). Seasonal or intense periodic rainfalls in an arid, sparsely-vegetated interior would have resulted in high rates of erosion and sediment delivery during periodic flash floods.

The shift to smectite and kaolinite content at the Smithian/Spathian boundary may correspond to an observed change in the Early Triassic climate regime. At this time within eastern Pangea, a shift in climate from humid, with higher rainfall to more arid is observed through ammonoid and plant fossil assemblages (Galfetti et al., 2007a,b; Romano et al., 2013). On the west coast of Pangaea, arid conditions already existed, although a shift to an even more arid climate would correlate with an increase in smectite content observed in samples from this study (Ruffell et al., 2002a, b). Additionally, a decrease in rainfall across this boundary, and a concomitant decrease in the proportion of sediment delivered by perennial river systems versus that delivered by ephemeral fluvial systems, is consistent with the observed drop in clay content. Interestingly, the points of highest detrital input, and the lowest relative sea-level, correspond to the climatic shift at the Smithian/Spathian boundary and the Early Triassic/Middle Triassic transition. Generally speaking, climatic 
changes may then correspond to longer-term shoreline shifts. Although it could be argued that the changes in detrital and clay indicators may reflect fluctuations in the fluvial system due to climate or hinterland changes, the correspondence of the shoreline (current study) shifts with those of Davies et al. (1997) suggest that these proxies accurately model relative sea-level changes. Additionally, if these changes indeed reflect shifts in fluvial input associated with climate, the observed modelled climate changes would be expected to correspond to each inferred shoreline shift. Based on these observations, the changes in clay and detrital input are interpreted to be reflective of relative sea-level change.

\section{Identification of clinoforms and implication for sequence stratigraphy in fine-grained}

\section{successions}

The chemostratigraphic correlation presented here implies that the sample sets from western Alberta (11-20-082-2W6 and 2-30-070-27W5) are lacking the uppermost chemostratigraphic intervals observable in British Columbia (Fig. 6). This signifies a significant loss of strata that could be the result of considerable erosion following clinoform deposition, as first suggested by Davies et al. (1997). The Montney/Doig contact has been recognized as being unconformable and chronostratigraphic, corresponding to the Lower/Middle Triassic boundary (Davies et al., 1997). The model of Montney Formation deposition presented herein shows that the 'Upper Montney' of Alberta is, in fact, temporally equivalent to the lower horizons in British Columbia (Fig. 17).

The identification of clinoform surfaces within the current study's data set suggests that geochemical data, such as detrital and clay proxies, can be used to identify stratigraphic sequences. Because the detrital signatures used for correlation show consistent and correlatable patterns in all of the data sets (which span the palaeobasin), and these 
signatures tie into relative sea-level and climatic changes observed elsewhere, with the chemostratigraphic units appearing to be chronostratigraphic in nature and not merely lithostratigraphic. The identification of stratigraphic sequences using chemostratigraphic analysis in the past has been done largely using isotopic analysis, such as $\delta^{13} \mathrm{C}$ or $\delta^{15} \mathrm{~N}($ e.g. Pelechaty, 1998; Nance \& Rowe, 2015), while correlations have relied heavily on biostratigraphic frameworks (e.g. Bergström et al., 2010). In contrast, results in this study suggest that inorganic chemical analysis, which can be generated both non-destructively and in situ using a portable X-ray fluorescence spectrometer (Rowe et al., 2012), allow for the identification of depth-bound chemofacies corresponding to subsurface clinoforms in fine-grained successions on a basin-wide scale. Indeed, cyclic variations in sediment provenance have already been identified as allowing for the identification of transgressive surfaces in alluvial, littoral and shallow-marine deposits from Italy (Amorosi, et al., 2007). In this case, transgressive surfaces were found to correspond to peaks in $\mathrm{Ni} / \mathrm{Al}$ content, and maximum flooding surfaces were characterized by high $\mathrm{Mg} / \mathrm{Al}$ values that correspond to a change in sediment sourcing during shoreline migration. While Amorosi et al. (2007) focused on two wells, the correlation of these peaks in $\mathrm{Ni} / \mathrm{Al}$ and $\mathrm{Mg} / \mathrm{Al}$ within a regional cross-section would, in theory, produce clinoform surfaces.

Perhaps some of the most well-documented and well-studied instances using geochemical data to demonstrate relative sea-level changes in the literature involve Cretaceous deposits. For example, a state of low relative sea-level has been identified in Late Cretaceous deposits that correlates with increased terrigenous input, low kaolinite/chlorite + mica ratios, high Sr/Ca ratios, and high TOC; conversely, high relative sea-level may generally be associated with the inverse of these indicators (Li et al., 2000). This correlation of detrital input with relative sea-level has also been demonstrated in 
Cretaceous deposits (Adatte et al., 2002; Chenot et al., 2016; Keller et al., 2016; Petrash et al., 2016). In fact, changes in clay content and detrital input have been recognized as providing reliable relative sea-level proxies, as well as climate, even in deep marine environments (Li et al., 2000). During periods of transgression and rising sea-level, clay input predominates, while during regression and relative sea-level fall, detrital input increases (Fig. 16).

When compared with second and third order relative sea-level curves for the Early Triassic (Haq et al., 1987; Embry \& Gibson, 1995; Davies et al., 1997), this data correlates well by showing instances of relative sea-level fall at the end of the Dienerian, the end of the Smithian, within the Spathian, and at the end of the Spathian (Fig. 16). While global correlations of sea-level can be problematic, the proxies used for detrital input ( $\mathrm{Sc} / \mathrm{Zr}$ and $\mathrm{Lu} / \mathrm{Hf}$ ) and clay input ( $\mathrm{Zr} / \mathrm{La}$ ) provide reliable information about basin-scale relative sea-level change. Consistency in these signatures across the basin indicates that causative events were regional in nature, allowing for clinoforms to be delineated. In addition to surfaces inferred to be global in nature (Barclay et al., 1990; Davies et al., 1997), three additional periods of relative sea-level rise and marine transgressions are suggested by the data. Additional relative sea-level rises occur within the Griesbachian, Dienerian and Spathian. Whether these reflect localized tectonic influences, or larger-scale sea-level changes, remains unclear. It has been suggested that the basin margin was tectonically active during deposition of the Montney Formation, and therefore, tectonic activity may be the driving factor. Fault reactivation and subsidence within the graben complexes of the collapsed Peace River Arch is thought to have influenced Montney deposition (Barclay et al., 1990; Davies et al., 1997). The collapsed Peace River Arch forms the basis for the Peace River Embayment, wherein the Montney Formation was deposited. In addition, recent evidence 
has indicated that accretion of pericratonic terranes to the northwestern autochthon was initiated during the Lower Triassic (Berenak et al., 2010). These terrane accretions would have had broad regional influences and may have been a primary driving force in relative sea-level throughout the studied interval (Ferri \& Zonneveld, 2008), specifically with regards to the additional sea-level changes noted within the current data set.

An active tectonic margin agrees well with observations in this study of felsic signatures and the pattern of change the data exhibits stratigraphically. Felsic signatures, as recorded by elevated Th/Sc and $\mathrm{Cr} / \mathrm{Th}$ cross-plots (Condie \& Wronkiewicz, 1989; Totten et al., 2000; Bracciali et al., 2007), have been identified in well 16-17-83-25W6 (Fig. 9). The increase of felsic input up-section (Fig. 9) may be associated with the approach of the Yukon-Tanana terrane from the west (Beranek \& Mortensen, 2011), and partial contribution from a western sediment source to Montney sediments. Detrital zircon and monazite analyses (Beranek \& Mortensen, 2011) indicate that the Yukon-Tanana terrane was situated just off the west coast of Pangaea by the Early-Middle Triassic and that by the late Triassic the terrane had been fully accreted onto the continental margin. The cross-plots of La/Sm and $\mathrm{Yb} / \mathrm{Sm}$ in this study suggest volcanic arc signatures within the Doig samples (Fig. 8), indicating that terrain accretion was well underway by the Anisian. This approaching terrane may be linked to fault reactivation and hydrothermal activity, specifically related to the horst and graben complexes associated with the collapsed Peace River Arch within the basin during the Early Triassic (Ferri \& Zonneveld, 2008). This, in addition to the migration of the back-bulge associated with the approaching terrane, could explain why the additional relative sea-level changes, identified in this study's data, have not been recognized globally. 


\section{CONCLUSIONS}

The goal of this study was to demonstrate the applicability of chemostratigraphic analysis for determining chronostratigraphic surfaces in fine-grained successions, using the Triassic Montney Formation as a field example. Utilizing geochemical trends to highlight changes in provenance, mineralogy, clay and detrital input proved useful in pinpointing changes in relative sea-level, climate change and hydrothermal input. Analysis of geochemical profiles revealed 13 distinct chemofacies that can be identified across the basin. Correlation of these facies reveals broad clinoform surfaces that indicate the upper Montney Formation in Alberta is temporally equivalent to lower-mid-Montney deposits in British Columbia. Additionally, analysis of clay proxies indicates high sedimentation rates within the Griesbachian and Dienerian Montney deposits and a correspondent shift in climate and sediment sourcing that is observable at the Smithian/Spathian boundary. This climatic shift is indicated by the point of highest detrital input and lowest relative sea-level within the preserved Montney deposits.

Cross-plots of $\mathrm{La} / \mathrm{Sm}$ and $\mathrm{Yb} / \mathrm{Sm}$ probably reveal hydrothermal input during the time immediately following the Smithian/Spathian boundary, as well as the scavenging of middle rare earth elements (MREE) by phosphate. Depleted MREE patterns within these hydrothermally influenced samples are suggestive of either the dissolution of phosphatic debris by hydrothermal fluids and loss of MREE, or the primary scavenging of phosphate by hydrothermal plume particulates and subsequent loss of MREE. These observations coincide with dolomite-rich horizons suggesting that hydrothermal fluid interaction accounts for at least part of the dolomitization within the Montney Formation. The presence of phosphatic debris immediately below this interval suggests that the diagenetic influence from the hydrothermal fluids was localized.

This article is protected by copyright. All rights reserved. 
Additionally, early accretion of the Yukon-Tanana terrane is surmised to have occurred by the Early Anisian. This is supported by cross-plots of $\mathrm{Th} / \mathrm{Sc}$ versus $\mathrm{Cr} / \mathrm{Th}$, which indicate increasing felsic input up-section. Moreover, plots of $\mathrm{La} / \mathrm{Sm}$ versus $\mathrm{Yb} / \mathrm{Sm}$ show volcanic arc input within the Doig Formation. Collectively, these lines of evidence imply an additional, western source of sediment input by the Anisian. This is significant as it supports the early-terrane accretion model (e.g. Beranek et al., 2010) which argues that accretion began during the Triassic along the western coast of Canada.

Overall, this study demonstrates that geochemical trends can be used to correlate fine-grained successions and highlight detailed, chronostratigraphic changes such as relative sea-level, hydrothermal input and climate when lithological homogeneity and poor palaeontological control exist.

\section{ACKNOWLEDGEMENTS}

This research was made possible by support received from the Natural Sciences and Engineering Research Council of Canada and the Geological Survey of Alberta. LJR gratefully acknowledges a Vanier Canada Graduate Scholarship. Additional thanks are given to Michelle Speta for her assistance with figure drafting. This manuscript benefited greatly from helpful comments provided by an anonymous reviewer, Dr. L. Birgenheier (University of Utah), the Associate Editor (Dr. T.D. Frank), and the Editor (Dr. P. Pufahl).

\section{REFERENCES}

Algeo, T.J. and Lyons, T.W. (2006) Mo-total organic carbon covariation in modern anoxic marine environments: implications for analysis of paleoredox and paleohydrographic conditions. Paleoceanography, 21, PA1016. 
Algeo, T. J. and Twitchett, R.J. (2010) Anomalous Early Triassic sediment fluxes due to elevated weathering rates and their biological consequences. Geology, 38, 10231026.

Algeo, T.J., Schwark, L. and Hower, J.C. (2004) High-resolution geochemistry and sequence stratigraphy of the Hushpuckney Shale (Swope Formation, eastern Kansas): implications for climate-environmental dynamics of the Late Pennsylvanian Midcontinent Seaway. Chemical Geology, 206, 259-288.

Adatte, T., Keller, G. and Stinnesbeck, W. (2002) Late Cretaceous to early Paleocene climate and sea-level fluctuations: the Tunisian record. Palaeogeography, Palaeoclimatology, Palaeoecology, 178, 165-196.

Amorosi, A., Colalongo, M.L., Dinelli, E., Lucchini, F. and Vaiani, S.C. (2007). Cyclic variations in sediment provenance from late Pleistocene deposits of the eastern Po Plain, Italy. In: Sedimentary Provenance and Petrogenesis: Perspectives from Petrography and Geochemistry (Eds J. Arribas, S. Critelli and M.J. Johnsson), GSA Spec. Paper, 420, 13-24.

Anbar, A.D. and Rouxel, O. (2007) Metal stable isotopes in paleoceanography. Annual Review of Earth and Planetary Sciences, 35, 717-746.

Armstrong-Altrin, J.S., Lee, Y.I., Verma, S.P. and Ramasamy, S. (2004) Geochemistry of sandstones from the Upper Miocene Kudankulam Formation, southern India: 
implications for provenance, weathering, and tectonic setting. Journal of Sedimentary Research, 74, 285-297.

Arthur, M.A., Jenkyns, H.C. and Brumsack, H.J. (1990) Stratigraphy, geochemistry, and paleoceanography of organic carbon-rich Cretaceous sequences. In: Cretaceous Resources, Events and Rhythms (Eds R.N. Ginsburg, and B. Beaudoin), pp. 75-119. Kluwer Academic Publishing, Amsterdam.

Asael, D., Tissot, F.L.H., Reinhard, C.T., Rouxel, O., Dauphas, N., Lyons, T., Ponzevera, Liorzou, C. and Chéron, S. (2013) Coupled molybdenum, iron and uranium stable isotopes as oceanic paleoredox proxies during the Paleoproterozoic Shunga Event. Chemical Geology, 362, 193-210.

Banner, J.L. (1995) Application of the trace element and isotope geochemistry of strontium to studies of carbonate diagenesis. Sedimentology, 42, 805-824.

Barclay, J.E., Krause, E.E., Campbell, R.I. and Utting, J. (1990) Dynamic casting and growth faulting: Dawson Creek Graben Complex, Carboniferous- Permian Peace River Embayment, western Canada. In: Geology of the Peace River Arch (Eds S.C. O'Connell and J.S. Bell). Bulletin of Canadian Petroleum Geology, v. 38A, p. 115-145.

Beatty, T.W., Zonneveld, J.-P. and Henderson, C.M., (2008) Anomalously diverse Early Triassic ichnofossil assemblages in northwest Pangaea: a case for a shallow-marine habitable zone. Geology, 36, 771-774.

This article is protected by copyright. All rights reserved. 
Benedicto, A., Degueldre, C. and Missana, T. (2014) Gallium sorption on montmorillonite and illite colloids: experimental study and modeling by ionic exchange and surface complexation. Applied Geochemistry, 40, 43-50.

Beranek, L.P., Mortensen, J.K., Orchard, M.J. and Ullrich, T. (2010) Provenance of North American Triassic strata from west-central and southeastern Yukon: correlations with coeval strata in the Western Canada Sedimentary Basin and Canadian Arctic Islands. Canadian Journal of Earth Sciences, 47, 53-73.

Beranek, L.P. and Mortensen, J.K. (2011) The timing and provenance record of the Late Permian Klondike orogeny in northwestern Canada and arc-continent collision along western North America. Tectonics, 30, TC5017.

Bergström, S.M., Young, S. and Schmitz, B. (2010) Katian (Upper Ordovician) $\delta^{13} \mathrm{C}$ chemostratigraphy and sequence stratigraphy in the United States and Baltoscandia: a regional comparison. Palaeogeography, Palaeoclimatology, Palaeoecology, 296, 217-234.

Berner, R.A. and Westrich, J.T. (1985) Bioturbation and the early diagenesis of carbon and sulphur. American Journal of Science, 285, 193-206. 
Bhatia, M.R. and Crook, K.A.W. (1986) Trace element characteristics of graywackes and tectonic setting discrimination of sedimentary basins. Contributions to Mineralogy and Petrology, 92, 181-193.

Bonjour, J.L. and Dabard, M.P. (1991) Ti/Nb ratios of clastic terrigenous sediments used as an indicator of provenance. Chemical Geology, 91, 257-267.

Bracciali, L., Marroni, M., Pandolfi, L. and Rocchi, S. (2007) Geochemistry and petrography of Western Tethys Cretaceous sedimentary covers (Corsica and Northern Apennines): from source areas to configuration of margins. In: Sedimentary Provenance and Petrogenesis: Perspectives from Petrography and Geochemistry (Eds J. Arribas, S. Critelli and M.J. Johnsson). GSA Spec. Paper, 420, 73-93.

Brumsack, H-J. (2006) The trace metal content of recent organic carbon-rich sediments: implications for Cretaceous black shale formation. Palaeogeography, Palaeoclimatology, Palaeoecology, 232, 344-361.

Calvert, S.E. and Pedersen, T.F. (1993) Geochemistry of recent oxic and anoxic marine sediments: implications for the geological record. Marine Geology, 113, 67-88.

Canfield, D.E., Thamdrup, B. and Hansen, J.W., (1993) The anaerobic degradation of organic matter in Danish coastal sediments: iron reduction, manganese reduction, and sulfate reduction. Geochimica et Cosmochimica Acta, 57, 3867-3883.

This article is protected by copyright. All rights reserved. 
Carpenter, S.J. and Lohmann, K.C. (1992) Sr/Mg ratios of modern marine calcite: empirical indicators of ocean chemistry and precipitation rate. Geochimica et Cosmochimica Acta, 56, 1837-1849.

Chamley, H. (1989) Clay Sedimentology. Springer-Verlag, Berlin, Heidelberg, 623 pp.

Chappaz, A., Lyons, T.W., Gregory, D.D., Reinhard, C.T., Gill, B.C., Li, C. and Large, R.R. (2014) Does pyrite act as an important host for molybdenum in modern and ancient euxinic sediments? Geochimica et Cosmochimica Acta, 126, 112-122.

Chaudhri, A.R. and Singh, M. (2012) Clay minerals as climate change indicators-a case study. American Journal of Climate Change, 1, 231-239.

Chen, Y., Twitchett, R.J., Jiang, H., Richoz, S., Lai, Z., Yan, C., Sun, Y., Liu, X. and Wang, L. (2013) Size variation of conodonts during the Smithian-Spathian (Early Triassic) global warming event. Geology, 41, 823-826.

Chenot, E., Pellenard, P., Martinez, M., Deconinck, J.-F., Amiotte-Suchet, P., Thibault, N., Bruneau, L., Cocquerez, T., Laffont, R., Pucéat, E. and Robaszynski, R. (2016) Clay mineralogical and geochemical expressions of the "Late Campanian Event" in the Aquitaine and Paris basins (France): palaeoenvironmental implications. Palaeogeography, Palaeoclimatology, Palaeoecology, 447, 42-52.

Cingolani, C.A., Manassero, M. and Abre, P. (2003) Composition, provenance and tectonic 
setting of Ordovician siliciclastic rocks in the San Rafael block: Southern extension of the Precordillera crustal fragment, Argentina. Journal of South American Earth Sciences, 16, 91-106.

Clift, P.D., Wan, S. and Blusztajn, J. (2014) Reconstructing chemical weathering, physical erosion and monsoon intensity since $25 \mathrm{Ma}$ in the northern South China Sea: a review of competing proxies. Earth-Science Reviews, 130, 86-102.

Condie, K.C. and Wronkiewicz, D.J. (1989) The $\mathrm{Cr} / \mathrm{Th}$ ratio in Precambrian pelites from the Kaapvaal Craton as an index of craton evolution. Earth and Planetary Science Letters, 97, 256-267.

Croudace, I.W., Rindby, A. and Rothwell, R.G. (2006) ITRAX: description and evaluation of a new multi-function X-ray core scanner. Geological Society Special Publications, London, 51-63.

Curtis, C.D., Coleman, M.L. and Love, L.G. (1986) Pore water evolution during sediment burial from isotopic and mineral chemistry of calcite, dolomite and siderite concretions. Geochimica et Cosmochimica Acta, 50, 2321-2334.

Cuven, S., Francus, P. and Lamoureux, S.F. (2010) Estimation of grain size variability with micro X-ray fluorescence in laminated sediments, Cape Bounty, Canadian High Arctic, Journal of Paleolimnology, 88, 803-817.

This article is protected by copyright. All rights reserved. 
Dai, S., Ren, D., Chou, C-L., Li, S. and Jiang, Y. (2006) Mineralogy and geochemistry of the No. 6 Coal (Pennsylvanian) in the Junger coalfield, Ordos Basin, China. International Journal of Coal Geology, 66, 253-270.

Dai, S., Li, D., Chou, C-L., Zhao, L., Zhang, Y., Ren, D., Ma, Y. and Sun, Y. (2008) Mineralogy and geochemistry of boehmite-rich coals: new insights from the Haerwusa Surface Mine, Jungar Coalfield, Inner Mongolia, China. International Journal of Coal Geology, 74, $185-202$.

Dai, S., Ren, D., Chou, C-L., Finkelman, R.B, Seredin, V.V. and Zhou, Y. (2012a) Geochemistry of trace elements in Chinese coals: a review of abundances, genetic types, impacts on human health, and industrial utilization. International Journal of Coal Geology, 94, 3-21.

Dai, S., Zhou, J., Jiang, Y., Ward, C.R., Wang, X., Li, T., Xue, W., Liu, S., Tian, H., Sun, X. and Zhou, D. (2012b) Mineralogical and geochemical compositions of the Pennsylvanian coal in the Adaohai Mine, Daqingshan Coalfield, Inner Mongolia, China: modes of occurrence and origin of diaspora, gorceixite, and ammonian illite. International Journal of Coal Geology, 94, 250-270.

Davies, G.R. (1997) The Triassic of the Western Canada Sedimentary Basin: tectonic and stratigraphic framework, paleogeography, paleoclimate and biota. Bulletin of Canadian Petroleum Geology, 45, 434-460.

This article is protected by copyright. All rights reserved. 
Davies, G.R., Moslow, T.F. and Sherwin, M.D. (1997) The Lower Triassic Montney

Formation, west-central Alberta. In: Triassic of the Western Canada Sedimentary

Basin. (Eds T.F. Moslow and J. Wittenberg), Bulletin of Canadian Petroleum Geology, 45, 474-505.

Dean, W., Anderson, R., Bradbury, J.P. and Anderson, D. (2002) A 1500-year record of climatic and environmental change in Elk Lake, Minnesota-I: a varve thickness and gray-scale density. Journal of Paleolimnology, 27, 287-299.

Deutsch, C.V. (2002) Geostatistical Reservoir Modeling. Oxford University Press. 376pp.

Dinelli, E., Tateo, F. and Summa, V. (2007). Geochemical and mineralogical proxies for grain size in mudstones and siltstones from the Pleistocene and Holocene of the Po River alluvial plain, Italy. From source areas to configuration of margins. In: Sedimentary Provenance and Petrogenesis: Perspectives from Petrography and Geochemistry (Eds J. Arribas, S. Critelli and M.J. Johnsson), GSA Spec. Paper, 420, 25-36.

Dixon, J. (2000) Regional lithostratigraphic units in the Triassic Montney Formation of western Canada. Bulletin of Canadian Petroleum Geology, 48, 80-83.

Edwards, D.E., Barclay, J.E., Gibson, D.W., Kvill, G.E. and Halton, E. (1994) Triassic strata of the Western Canada Sedimentary Basin. In: Geological Atlas of the Western Canada Sedimentary Basin, Canadian Society of Petroleum Geologists and Alberta Research Council (Eds G.D. Mossop and I. Shetsen). Available at

This article is protected by copyright. All rights reserved. 
http://www.ags.gov.ab.ca/publications/wcsb_atlas/atlas.html.

Ellwood, B.B., Tomkin, J.H., Ratcliffe, K.T., Wright, M. and Kafafy, A.M. (2008). Highresolution magnetic susceptibility and geochemistry for the Cenomanian/Turonian boundary GSSP with correlation to time equivalent core. Palaeogeography, Paleoclimatology, Palaeoecology, 261, 105-126.

Embry, A.F. and Gibson, D.W. (1995) T-R sequence analysis of the Triassic succession of the Western Canada Sedimentary Basin. In: Proceedings of the Oil and Gas Forum '95 Energy from Sediments (Eds J.S. Bell, T.D. Bird, T.L. Hillier and EL. Greener), Geological Survey of Canada, Open File 3058, 25-32.

Esser, K.B., Bockheim, J.G. and Helmke, P.A. (1991) Trace element distribution in soils formed in the Indiana Dunes, U.S.A. Soil Science, 152, 340-350.

Feely, R.A., Massoth, G.J., Trefry, J.H., Baker, E.T., Paulson, A.J. and Lebon, G.T. (1994) Composition and sedimentation of hydrothermal plume particles from North Cleft segment, Juan de Fuca Ridge. Journal of Geophysical Research, 99, 4985-5006.

Fein, J.B., Daughney, C.J., Yee, N. and Davis, T.A. (1997) A chemical equilibrium model for metal adsorption onto bacterial surfaces. Geochimica et Cosmochimica Acta, 61, 3319-3328.

This article is protected by copyright. All rights reserved. 
Ferri, F, and Zonneveld, J.-P. (2008) Were Triassic rocks of the Western Canada Sedimentary Basin deposited in a Foreland? Canadian Society of Petroleum Geologists Reservoir, 35, 12-14.

Froelich, P.N., Klinkhammer, G.P., Bender, M.L., Luedtke, N.A., Heath, G.R., Cullen, D., Dauphin, P., Hammond, D., Hartman, B. and Maynard, V. (1979) Early oxidation of organic matter in pelagic sediments of the eastern equatorial Atlantic: suboxic diagenesis. Geochimica et Cosmochimica Acta, 43, 1075-1090.

Gadd, G.M. (2010) Metals, minerals and microbes: geomicrobiology and bioremediation. Microbiology, 156, 609-643.

Galfetti, T., Hochuli, P.A., Brayard, A., Bucher, H., Weissert, H. and Os Vigran, J. (2007a) Smithian-Spathian boundary event: evidence for global climatic change in the wake of the end-Permian biotic crisis. Geology, 35, 291-294.

Galfetti, T., Bucher, H., Braynard, A., Hochuli, P.A., Weissert, H., Guodun, H., Atudorei, V. and Guex, J. (2007b) Late Early Triassic climate change: insights from carbonate carbon isotopes, sedimentary evolution and ammonoid paleobiogeography. Palaeogeography, Palaeoclimatology, Palaeoecology, 243, 394-411.

Golding, M.L., Orchard, M.J., Zonneveld, J.-P., Henderson, C.M. and Dunn, L. (2014) An exceptional record of the sedimentology and biostratigraphy of the Montney and 
Doig formations in British Columbia. Bulletin of Canadian Petroleum Geology, 62, 157-176.

Golonka, J., Ross, M.I. and Scotese, C.R. (1994) Phanerozoic paleogeographic and paleoclimatic modeling maps. In: Pangea: Global Environment and Resources (Eds A.F. Embry, B. Beauchamp and D.J. Glass), CSPG Memoir, 17, 1-47.

Golonka, J. and Ford, D. (2000) Pangean (Late Carboniferous - Middle Jurassic) paleoenvironment and lithofacies. Palaeogeography, Palaeoclimatology, Palaeoecology, 161, 1-34.

Hays, L.E., Beatty, T.W., Henderson, C.M., Love, G.D. and Summons, R.E. (2007) Evidence for photic zone euxinia through the end-Permian mass extinction in the Panthalassic Ocean (Peace River Basin, Western Canada). Palaeoworld, 16, 39-50.

Haq, B.V., Hardenbol, J., Vail, RR., Colin, J.P., loannides, N., Stover, L.E., Jan Du Chene, R., Wright, R.C., Sarq, J.F. and Morgan, B.E. (1987) Mesozoic-Cenozoic Cycle Chart, Version 3.IB. American Association of Petroleum Geologists.

Hildred, G.V., Ratcliffe, K.T., Wright, A.M., Zaitlin, B.A. and Wray, D.S. (2010) Chemostratigraphic applications to low-accommodation fluvial incised-valley settings: an example from the lower Mannville Formation of Alberta, Canada. Journal of Sedimentary Research, 80, 1032-1045. 
Hofer, G., Wagreich, M. and Neuhuber, S. (2013) Geochemistry of fine-grained sediments of the upper Cretaceous to Paleogene Gosau Group (Austria, Slovakia): implications for paleoenvironmental and provenance studies. Geoscience Frontiers, 4, 449-468.

Hofmann, A., Bolhar, R., Dirks, P. and Jelsma, H. (2003) The geochemistry of Archaean shales derived from a mafic volcanic sequence, Belingwe greenstone belt, Zimbabwe: provenance, source area unroofing and submarine versus subaerial weathering. Geochimica et Cosmochimica Acta, 67, 421-440.

Israel, M.B., Enzel, Y., Amit, R. and Erel, Y. (2015) Provenance of the various grain-size fractions in the Negev loess and potential changes in major dust sources to the Eastern Mediterranean. Quaternary Research, 83, 105-115.

Jarvis, I. and Jarvis, K. (1992) Plasma spectrometry in the earth sciences: techniques, applications and future trends. Chemical Geology, 95, 1-33.

Jin, X., Shah, S.N., Roegiers, J.-C. and Zhang, B. (2015) An integrated petrophysics and geomechanics approach for fracability evaluation in shale reservoirs. SPE Journal, 20, 518-526.

Johnson, R.A. and Wichern, D.W. (1988) Applied Multivariate Statistical Analysis. Prentice Hall, New Jersey, 773 pp.

This article is protected by copyright. All rights reserved. 
Jones, B. and Manning, A.C. (1994) Comparison of geochemical indices used for the interpretation of palaeoredox conditions in ancient mudstones. Chemical Geology, 111, 111-129.

Keller, G., Jaiprakash, B.C. and Reddy, A.N. (2016) Maastrichtian to Eocene subsurface stratigraphy of the Cauvery Basin and correlation with Madagascar. Journal Geological Society of India, 87, 5-34.

Kendall, B., Gordon, G.W., Poulton, S.W. and Anbar, A.D. (2011). Molybdenum isotope constraints on the extent of late Paleoproterozoic ocean euxinia. Earth and Planetary Science Letters, 307, 450-460.

Lalonde, S.V., Smith, D.S., Owttrim, G.W. and Konhauser, K.O. (2008) Acid-base properties of cyanobacterial surfaces I: influences of growth phase and nitrogen metabolism on cell surface reactivity. Geochimica et Cosmochimica Acta, 72, 1257-1268.

Lev, S.M., McLennan, S.M. and Hanson, G.N. (1999) Mineralogic controls on REE mobility during black-shale diagenesis. Journal of Sedimentary Research, 69, 1071-1082

Li, L., Keller, G., Adatte, T. and Stinnesbeck, W. (2000) Late Cretaceous sea-level changes in Tunisia: a multi-disciplinary approach. Journal of the Geological Society of London, $157,447-458$.

This article is protected by copyright. All rights reserved. 
Liang, A., Paulo, C., Zhu, Y. and Dittrich, M. (2013) $\mathrm{CaCO}_{3}$ biomineralization on cyanobacterial surfaces: Insights from experiments with three Synechococcus strains. Colloids and Surfaces B: Biointerfaces, 111, 600-608.

Liermann, L.J., Mathur, R., Wasylenki, L.E., Nuester, J., Anbar, A.D. and Brantley, S.L. (2011) Extent and isotopic composition of Fe and Mo release from two Pennsylvania shales in the presence of organic ligands and bacteria. Chemical Geology, 281, 167180.

López de Luchi, M. G., Cerredo, M.E., Siegesmund, S., Steenken, A. and Wemmer, K. (2003) Provenance and tectonic setting of the protoliths of the Metamorphic Complexes of Sierra de San Luis. Revista de la Asociación Geológica Argentina, 58, 525-540.

MacNaughton, R.B. and Zonneveld, J.-P. (2010) Trace-fossil assemblages in the Lower Triassic Toad Formation, La Biche River map area, southeastern Yukon. Bulletin of Canadian Petroleum Geology, 58, 100-114.

McLennon, S.M., Taylor, S.R., McCulloch, M.T. and Maynard, J.B. (1990) Geochemical and $\mathrm{Nd}-\mathrm{Sr}$ isotopic composition of deep-sea turbidites: crustal evolution and plate tectonic associations. Geochemica et Cosmochimica Acta, 54, 2015-2050.

McLennon, S.M., Hemming, S., McDaniel, D.K. and Hanson, G.N. (1993) Geochemical approaches to sedimentation, provenance, and tectonics. GSA Spec. Paper, 284, 2140. 
Meinhold, G., Kostopoulos, D., and Reischmann, T. (2007) Geochemical constraints on the provenance and depositional setting of sedimentary rocks from the islands of Chios, Inousses and Psara, Aegean Sea, Greece: implications for the evolution of Palaeotethys. Journal of the Geochemical Society, London, 164, 1145-1163.

Mongelli, G., Critelli, S., Perri, F., Sonnino, M. and Perrone, V. (2006) Sedimentary recycling, provenance and paleoweathering from chemistry and mineralogy of Mesozoic continental red-bed mudrocks, Peloritani mountains, southern Italy. Geochemical Journal, 40, 197-209.

Morton, J.P. (1985) Rb-Sr evidence for punctuated illite/smectite diagenesis in the Oligocene Fio Formation, Texas Gulf Coast. Geological Society of America Bulletin, 96, 114-122.

Morton, A.C. and Hallsworth, C. (1994) Identifying provenance-specific features of detrital heavy mineral assemblages in sandstones. Sedimentary Geology, 90, 241-256.

Morton, A. and Yaxley, G. (2007) Detrital apatite geochemistry and its application in provenance studies. GSA Spec. Paper, 420, 319-344.

Moslow, T.F. (2000) Reservoir architecture of a fine-grained turbidite system: Lower Triassic Montney Formation, Western Canada Sedimentary Basin. In: Deep-water reservoirs of the world (Eds P. Weimer, R.M. Slatt, J. Coleman, N.C. Rosen, H. Nelson, A.H. 
Bouma, M.J. Styzen and D.T. Lawrence). Conference Proceedings, Gulf Coast SEPM. 686-713.

Moslow, T.F. and Davies, G.R. (1997) Turbidite reservoir facies in the Lower Montney Formation, west-central Alberta. In: Triassic of the Western Canada Sedimentary Basin (Eds T.F. Moslow and J. Wittenberg), Bulletin of Canadian Petroleum Geology, 45, 507-536.

Nance, H.S. and Rowe, H. (2015) Eustatic controls on stratigraphy, chemostratigraphy, and water mass evolution preserved in a Lower Permian mudrock succession, Delaware Basin, west Texas, USA. Interpretation, 3, SH11-SH25.

North, C.P., Hole, M.J. and Jones, D.G. (2005) Geochemical correlation in deltaic successions: a reality check. GSA Bulletin, 117, 620-632.

Orchard, M.J. and Tozer, E.T. (1997) Triassic conodont biochronology, its calibration with the ammonoid standard, and a biostratigraphic summary for the Western Canada Sedimentary Basin. Bulletin of Canadian Petroleum Geology, 45, 675-692.

Orchard, M.J. and Zonneveld, J.-P. (2009) The Lower Triassic Sulphur Mountain Formation in the Wapiti Lake area: lithostratigraphy, conodont biostratigraphy, and a new biozonation for the lower Olenekian (Smithian). Canadian Journal of Earth Sciences, 46, 757-790. 
Paktunc, A.D. and Cabri, L.J. (1995) A proton- and electron-microprobe study of gallium, nickel and zinc distribution in chromium spinel. Lithos, 35, 261-282.

Paull, R.K., Paull, R.A. and Laudon, T.S. (1997) Conodont biostratigraphy of the Lower Triassic Mackenzie Dolomite Lentil, Sulphur Mountain Formation in the Cadomin area, Alberta. Bulletin of Canadian Petroleum Geology, 45, 708-714.

Patchett, P.J., White, W.M., Feldmann, H., Kielinczuk, S. and Hofmann, A.W. (1984) Hafnium/rare earth element fractionation in the sedimentary system and crustal recycling into the Earth's mantle. Earth and Planetary Science Letters, 69, 365-378.

Petrash, D.A., Gueneli, N., Brocks, J.J., Méndez, J.A., Gonzalez-Arismentdi, G., Poulton, S.W. and Konhauser, K.O. (2016) Black shale deposition and early diagenetic dolomite cementation during Oceanic Anoxic Event 1: the mid-Cretaceous Maracaibo Platform, northwestern South America. American Journal of Science, 316, 669-711.

Pett-Ridge, J.C., Derry, L.A. and Kurtz, A.C. (2009) Sr isotopes as a tracer of weathering processes and dust inputs in a tropical granitoid watershed, Luquillo Mountains, Puerto Rico. Geochimica et Cosmochimica Acta, 73, 25-43.

Pierson, B.J. (1981) The control of cathodoluminescence in dolomite by iron and manganese. Sedimentology, 28, 601-610. 
Planavsky, N.J., Asael, D., Hofmann, A., Reinhard, C.T., Lalonde, S.V., Knudsen, A., Wang, X., Ossa Ossa, F., Pecoits, E., Smith, A.J.B., Beukes, N.J., Bekker, A., Johnson, T.M., Konhauser, K.O., Lyons, T.W. and Rouxel, O.J. (2014) Evidence for oxygenic photosynthesis half a billion years before the Great Oxidation Event. Nature Geoscience, 7, 283-286.

Plank, T. and Langmuir, C.H. (1998) The chemical composition of subducting sediment and its consequences for the crust and mantle. Chemical Geology, 145, 325-394.

Playter, T., Konhauser, K., Owttrim, G., Hodgson, C., Warchola, T., Mloszewska, A.M., Sutherland, B., Bekker, A., Zonneveld, J.-P., Pemberton, S.G. and Gingras, M. (2017) Microbe-clay interactions as a mechanism for the preservation of organic matter and trace metal biosignatures in black shales. Chemical Geology, 459, 75-90.

Pearce, T.J., Besly, B.M., Wray, D.S. and Wright, D.K. (1999) Chemostratigraphy: a method to improve inter-well correlation in barren sequences - a case study using onshore Duckmantian/Stephanian sequences (West Midlands, U.K.). Sedimentary Geology, $124,197-220$.

Pearce, T.J., Wray, D., Ratcliffe, K., Wright, D.K. and Moscariello, A. (2005) Chemostratigraphy of the Upper Carboniferous Schooner Formation, southern North Sea. In: Carboniferous Hydrocarbon Resources: The Southern North Sea and Surrounding Onshore Areas (Eds J.D. Collinson, D.J. Evans, D.W. Holliday and N.S. Jones). Occasional Publications Series of the Yorkshire Geological Society, 7, 165-182. 
Pearce, T.J., Martin, J.H., Cooper, D. and Wray, D.S. (2010) Chemostratigraphy of Upper Carboniferous (Pennsylvanian) sequences from the southern North Sea (United Kingdom). In: Application of Modern Stratigraphic Techniques: Theory and Case Histories (Eds K. Ratcliffe and B.A. Zaitlin), SEPM Spec. Publ., 94, 109-127.

Pelechaty, S. (1998) Integrated chronostratigraphy of the Vendian system of Siberia: implications for a global stratigraphy. Journal of the Geological Society of London, 155, 957-973.

Pokrovsky, O.S., Martinez, R.E., Kompantzeva, E.I. and Shirokova, L.S. (2014) Surface complexation of the phototrophic anoxygenic non-sulfur bacterium Rhodopseudomonas palustris. Chemical Geology, 383, 51-62.

Preston, J., Hartley, A., Hole, M., Buck, S., Bond, J., Mange, M. and Still, J. (1998) Integrated whole-rock trace element geochemistry and heavy mineral chemistry studies: aids to correlation of continental red-bed reservoirs in the Beryl Field, UK North Sea. Petroleum Geoscience, 4, 7-16.

Rabouille, C. and Gaillard, J-F. (1991) Towards the EDGE: Early diagenetic global explanation. A model depicting the early diagenesis of organic matter, $\mathrm{O}_{2}, \mathrm{NO}_{3}, \mathrm{Mn}$ and $\mathrm{PO}_{4}$. Geochimica et Cosmochimica Acta, 55, 2511-2525. 
Ratcliffe, K.T., Wright, A.M., Hallsworth, C., Morton, A., Zaitlin, B.A., Potocki, D. and Wray, D.S. (2004) An example of alternative correlation techniques in a lowaccommodation setting, non-marine hydrocarbon system: the (Lower Cretaceous) Mannville Basal Quartz succession of southern Alberta. AAPG Bulletin, 88, 14191432.

Ratcliffe, K.T., Martin, J., Pearce, T.J., Hughes, A.D., Lawton, D.E., Wray, D.S. and Bessa, F. (2006) A regional chemostratigraphically - defined correlation framework for the late Triassic TAG - I Formation in Blocks 402 and 405a, Algeria. Petroleum Geoscience, 12, 3-12.

Ratcliffe, K.T., Wright, A.M., Montgomery, P., Palfrey, A., Vonk, A., Vermeulen, J. and Barrett, M. (2010) Application of chemostratigraphy to the Mungaroo Formation, the Gorgon Field, offshore Northwest Australia. APPEA Journal, $50^{\text {th }}$ Anniversary Issue, 371-388.

Ratcliffe, K.T., Wright, A.M. and Schmidt, K. (2012) Application of inorganic whole - rock geochemistry to shale resource plays: an example from the Eagle Ford Shale Formation, Texas. The Sedimentary Record, 10, 4-9.

Ratcliffe, K.T., Wilson, A., Payenberg, T., Rittersbacher, A., Hildred, G.V. and Flint, S.S. (2015) Ground truthing chemostratigraphic correlations in fluvial systems. AAPG Bulletin, 99, 155-180.

This article is protected by copyright. All rights reserved. 
Reategui, K., Martínez, M., Esteves, I., Gutiérrez, J.V., Martínez, A., Meléndez, W. and Urbani, F. (2005) Geochemistry of the Mirador Formation (Late Eocene - Early Oligocene) southwestern Venezuela: chemostratigraphic constraints on provenance and the influence of the sea level. Geochemical Journal, 39, 213-226.

Reddy, M.R. and Perkins, H.F. (1975) Fixation of zinc by clay minerals. Soil Science Society of America Journal, 38, 229-231.

Reinhard, C.T., Planavsky, N.J., Wang, X., Fischer, W.W., Johnson, T.M. and Lyons, T.W. (2014) The isotopic composition of authigenic chromium in anoxic marine sediments: a case study from the Cariaco Basin. Earth and Planetary Science Letters, 407, 9-18.

Retallack, G.J., Holser, W.T. and Isozaki, Y. (1997) Timing of Permian-Triassic anoxia. Science, 277, 1748-1749.

Richards, B.C., Barclay, J.E., Bryan, D., Hartling, A., Henderson, C.M. and Hinds, R.C. (1994) Carboniferous strata of the Western Canada Sedimentary Basin. In: Geological Atlas of the Western Canada Sedimentary Basin (Eds G.D. Mossop and I. Shetsen), Canadian Society of Petroleum Geologists and Alberta Research Council, 221-250.

Romano, C., Goudemand, N., Vennemann, T.W., Ware, D., Schneebeli-Hermann, E., Hochuli, P.A., Brühwiler, T., Brinkmann, W. and Bucher, H. (2013) Climatic and biotic upheavals following the end-Permian mass extinction. Nature Geoscience, $\mathbf{6}$, 57-60.

This article is protected by copyright. All rights reserved. 
Rowe, H., Hughes, N. and Robinson, K. (2012) The quantification and application of handheld energy-dispersive x-ray fluorescence (ED-XRF) in mudrock chemostratigraphy and geochemistry. Chemical Geology, 324-325, 122-131.

Ruffell, A.H. and Batton, D.J. (1990) The Barremian-Aptian arid phase in Western-Europe. Palaeogeography, Palaeoclimatology, Palaeoecology, 80, 197-212.

Ruffell, A.H., Price, G.D., Mutterlose, J., Kessels, K., Baraboshkin, E. and Gröcke, D.R. (2002a) Palaeoclimate indicators (clay minerals, calcareous nannofossils, stable isotopes) compared from two successions in the late Jurassic of the Volga Basin (SE Russia). Geological Journal, 37, 17-33.

Ruffell, A., McKinley, J.M. and Worden, R.H. (2002b) Comparison of clay mineral stratigraphy to other proxy palaeoclimate indicators in the Mesozoic of NW Europe. Philosophical Transactions of the Royal Society of London A: Mathematical, Physical and Engineering Sciences, 360, 675-693.

Rukhlov, A.S. and Pawlowicz, J.G. (2011) Magmatism and metallic mineralization of the Rocky Mountain Fold-and-Thrust Belt in Southwestern Alberta (NTS 82G, H and J): mineralogy, geochemistry and petrology of selected occurrences. ERCB/AGS Open File Report, 2011-11, 88pp.

Sanei, H., Haeri-Ardakani, O., Wood, J.M. and Curtis, M.E. (2015) Effects of nano-porosity 
and surface imperfections on solid bitumen reflectance (BRo) measurements in unconventional reservoirs. International Journal of Coal Geology, 138, 95-102.

Shlens, J. (2014) A tutorial on principal component analysis. arXiv preprint arXiv, 1404,1100.

Svendsen, J., Friis, H., Stollhofen, H. and Hartley, N. (2007) Facies discrimination in a mixed fluvio-eolian setting using elemental whole-rock geochemistry - applications for reservoir characterization. Journal of Sedimentary Research, 77, 23-33.

Takahashi, Y., Minai, Y., Ambe, S., Makide, Y. and Ambe, F. (1999) Comparison of adsorption behavior of multiple inorganic ions on kaolinite and silica in the presence of humic acid using the multi-tracer technique. Geochimica et Cosmochimica Acta, $63,815-836$.

Tan, P., Steinbeck, M. and Kumar, V. (2006) Introduction to Data Mining. 2nd edn. Pearson Education, New York, 769 pp.

Thiry, M. (2000) Palaeoclimatic interpretation of clay minerals in marine deposits: an outlook from the continental origin. Earth Science Reviews, 49, 201-221.

Tribovillard, N., Algeo, T.J., Lyons, T. and Ribouleau, A. (2006) Trace metals as paleoredox and paleoproductivity proxies: an update. Chemical Geology, 232, 12-32.

This article is protected by copyright. All rights reserved. 
Totten, M.W., Hanan, M.A. and Weaver, B.L. (2000) Beyond whole-rock geochemistry of shales: the importance of assessing mineralogical controls for revealing tectonic discriminants of multiple sediment sources for the Ouchita Mountain flysch deposits. GSA Bulletin, 112, 1012-1022.

Tozer, E.T. (1994) Canadian Triassic ammonoid faunas. Geological Survey of Canada Bulletin, 467, 1-663.

Tyler, G. (2004) Vertical distribution of major, minor, and rare elements in a Haplic Podzol. Geoderma, 119, 277-290.

Utting, J., MacNaughton, R.B., Zonneveld, J.-P. and Fallas, K. (2005) Palynostratigraphy, organic matter and thermal maturity of the Lower Triassic Toad, Grayling and Montney formations of Yukon, British Columbia and Alberta and comparison with the Sverdrup Basin, Nunavut. Bulletin of Canadian Petroleum Geology, 53, 5-24.

Wang, W., Qin, Y., Lui, X., Zhao, J., Wang, J., Wu, G. and Lui, J. (2011) Distribution, occurrence and enrichment causes of gallium in coals from the Jungar Coalfield, Inner Mongolia. Science China: Earth Sciences, 54, 1053-1068.

Ward, J. H., Jr. (1963) Hierarchical grouping to optimize an objective function. Journal of the American Statistical Association, 58, 236-244.

This article is protected by copyright. All rights reserved. 
Wedepohl, K.H. (1971) Environmental influences on the chemical composition of shales and clays. Physics and Chemistry of Earth (Eds. L.H. Ahrens, F. Press, S.K. Runcorn and H.C. Urey) 8, 307-331.

Wei, G., Liu, Y., Li, X., Shao, L. and Liang, X. (2003) Climatic impact on Al, K, Sc and Ti in marine sediments: evidence from ODP Site 1144, South China Sea. Geochemical Journal, 37, 593-602.

Wheat, C.G., Feely, R.A. and Mottl, M.J. (1996) Phosphate removal by oceanic hydrothermal processes: an update of the phosphorus budget in the oceans. Geochimica et Cosmochimica Acta, 60, 3593-3608.

Wright, A.M., Ratcliffe, K.T., Zaitlin, B.A. and Wray, D.S. (2010) The application of chemostratigraphic techniques to distinguish compound incised valleys in low accommodation incised valley systems in a foreland-basin setting: an example from the Lower Cretaceous Mannville Group and Basal Colorado Sandstone (Colorado Group), Western Canadian Sedimentary Basin. In: Application of Modern Stratigraphic Techniques, Theory and Case Histories (Eds K., Ratcliffe and B.A., Zaitlin). SEPM Spec. Publ., 94, 93-107.

Wood, J.M., Sanei, H., Curtis, M.E. and Clarkson, C.R. (2015) Solid bitumen as a determinant of reservoir quality in an unconventional tight gas siltstone play. International Journal of Coal Geology, 150-151, 287-295. 
Zhao, M-Y. and Zheng, Y-F. (2015) The intensity of chemical weathering: Geochemical constraints from marine detrital sediments of Triassic age in South China. Chemical Geology, 391, 111-122.

Zonneveld, J.-P. and Moslow, T.F. (in press) Depositional history and palaeogeographic evolution of the Montney in the Western Canada Sedimentary Basin. Bulletin of Canadian Petroleum Geology.

Zonneveld, J.-P. and Moslow, T. F. (2004) Exploration potential of the Falher G shoreface conglomerate trend: evidence from outcrop. Bulletin of Canadian Petroleum Geology, 52, 23-38.

Zonneveld, J.-P., Beatty, T.W. and Pemberton, S.G. (2007) Lingulide brachiopods and the trace fossil Lingulichnus from the Triassic of Western Canada: implications for faunal recovery after the end-Permian mass extinction. Palaios, 22, 74-97.

Zonneveld, J.-P., Gingras, M.K. and Beatty, T.W. (2010a) Diverse ichnofossil assemblages following the P-T mass extinction, Lower Triassic, Alberta and British Columbia, Canada: evidence for shallow marine refugia on the northwestern coast of Pangaea. Palaios, 25, 368-392.

Zonneveld, J.-P., MacNaughton, R.B., Utting, J., Beatty, T.W., Pemberton, S.G. and 
Henderson, C.M. (2010b) Sedimentology and ichnology of the Lower Triassic Montney Formation in the Pedigree-Ring/Border-Kahntah River area, northwestern Alberta and northwestern British Columbia. Bulletin of Canadian Petroleum Geology, 58, 115-140.

\section{Figure Captions}

Fig. 1. Palaeogeographic map outlining the location of all sample sets. Map after Zonneveld et al. (2011) and Blakey (2011). Sample locations are denoted by circles, an outcrop location is shown by an $\mathrm{x}$ and the type well is also marked. Locations of sample sets are as follows: (A) Ursula Creek outcrop; (B) 16-17-083-25W6; (C) c-74-G/94-B-9; (D) d-48-A/94-B-9, (E) 11 20-082-02W6; and (F) 2-30-070-24W5.

Fig. 2. Detrital indicator profiles for well 16-17-083-25W6. Depths are in metres.

Chemofacies are numbered from 1 to 13 (right). Simplified interpretations of concentrations are labelled at the base with arrows. For references, refer to the Elemental Indicators section in the text.

Fig. 3. Provenance indicator profiles for well 16-17-083-25W6. Depths are in metres. Chemofacies are numbered from 1 to 13 (right). Simplified interpretations of concentrations are labelled at the base with arrows. For references, refer to the Elemental Indicators section in the text.

Fig. 4. Clay indicator profiles for well 16-17-083-25W6. Depths are in metres. Chemofacies are numbered from 1 to 13 (right). Simplified interpretations of concentrations are labelled at the base with arrows. For references, refer to the Elemental Indicators section in the text. 
Fig. 5. Mineralogical indicator profiles for well 16-17-083-25W6. Depths are in metres. Chemofacies are numbered from 1 to 13 (right). Simplified interpretations of concentrations are labelled at the base with arrows. For references, refer to the Elemental Indicators section in the text.

Fig. 6. Line of cross-section illustrating the correlation between all sample sets used in this study: (A) Ursula Creek Outcrop; (B) 16-17-083-25W6; (C) c-74-G/94-B-9; (D) d-48-A/94-B-9; (E) 11-20-082-02W6; and (F) 2-30-070-24W5. The Spathian/Anisian (Lower/Middle Triassic) boundary was chosen as the datum as it is a chronostratigraphic boundary definitively present in all data sets. Gamma ray logs and Zr/La profiles are shown. Zones of correlated conodont horizons are indicated by stars. Of note is the loss of upper chemofacies in wells $C$ and $D$ and in the two Alberta wells ( $E$ and F; chemofacies 9 to 13 are not observed). This can be explained by a combination of erosion and clinoform deposition. Also of interest is the thickening of the lower chemofacies in wells $E$ and $F$, further supporting a clinoform model of deposition.

Fig. 7. Eigenvector plots of e1 versus e2 for all data sets. (A) Eigenvector plot of well 16-17083-25W6. Elemental clusters are indicated by black polygons: the MgO cluster (top), the heavy element cluster (central), $\mathrm{REE}+\mathrm{Y}$ cluster (right) and $\mathrm{Al}_{2} \mathrm{O}_{3}$ cluster (left). (B) Eigenvector plot of well 11-20-082-02W6. (C) Eigenvector plot of well Ursula Creek. (D) Eigenvector plot of well d-48-A/94-B-9. (E) Eigenvector plot of well 2-30-070-24W5, and (F) Eigenvector plot of well c-74-G/94-B-9.

This article is protected by copyright. All rights reserved. 
Fig. 8. Geochemical plots showing the distribution of light rare earth elements (LREE; $y$ axis) versus heavy rare earth elements (HREE; $x$ axis), after Plank and Langmuir (1998). (A) The influence of hydrothermal input, continental detritus, arc volcanics and clay sequestration are illustrated in the plot for well 16-17-083-25W6 sorted by chemofacies. (B) Plot for well 11-20-082-02W6. (C) Plot for Ursula Creek. (D) Plot for well d-48-A/94-B-9. (E) Plot for well 2-30-070-24W5. and (F) Plot for well c-74-G/94-B-9.

Fig. 9. Geochemical plot of the data from well 16-17-083-25W6 illustrating the influence of felsic (Th/Sc) versus mafic (Cr/Th) input (after Bracailli et al., 2007). Felsic, mafic and ultramafic trends are illustrated. Data points are coloured based on chemofacies (legend on the right). Doig samples (chemofacies 13), Belloy samples (chemofacies 1), and chemofacies 8 samples all show mafic, and ultramafic input. Additionally, felsic content increases stratigraphically upward (note change in facies colour along the $y$-axis).

Fig. 10. Geochemical plots illustrating the influence of felsic $(\mathrm{Th} / \mathrm{Sc})$ versus mafic $(\mathrm{Cr} / \mathrm{Th})$ input (after Bracailli et al., 2007) for data sets: (A) 11-20-082-02W6; (B) Ursula Creek; (C) d48-A/94-B-9; (D) 2-30-070-24W5; and (E) C-74-G/94-B-9.

Fig. 11. Cross-plot of Sr versus Mg values for the well 16-17-083-25W6. Biotic and abiotic trends are shown from Carpenter \& Lohmann (1992). Biotic and abiotic trends are shown from Carpenter \& Lohmann (1992).

This article is protected by copyright. All rights reserved. 
Fig. 12. Oxide, Sr and Ba profiles for well 16-17-083-25W6 with calcite cementation zones indicated by red and dolomite-rich zones highlighted in grey. Peaks in Sr correlate with calcite-rich zones. The gamma ray profile is given on the left.

Fig. 13. Depth-plot illustrating the variation in the ratio of $\mathrm{Fe} / \mathrm{S}, \mathrm{P} / \mathrm{Fe}$ (samples showing MREE depletion are shown) and Cu for well 16-17-083-25W6. Zones of high P/Fe are indicated by red bars. Depth is in metres ( $y$-axis). Within the plot of Fe/S, at depth $2400 \mathrm{~m}$, the character of the ratio value changes from low to high, suggesting a switch in the dominant iron-bearing phase from pyrite to iron oxyhydroxide.

Fig. 14. Phosphorus/iron values for wells 2-30-070-24W5, 11-20-082-02W6, c-74-G/94-B-9, d-48-A/94-B-9 and Ursula Creek. Intervals with values greater than 0.12 (the lower limit of hydrothermal influence) are highlighted in green.

Fig. 15. Rare earth element (REE) plots showing the typical pattern observed in the sample set compared to anomalous patterns observed at $2367.6 \mathrm{~m}$ and $2368 \mathrm{~m}$ : REE data are normalized to chondrite values and MREE deletion is clearly illustrated for depths of 2367.6 $\mathrm{m}$ and $2368 \mathrm{~m}$.

Fig. 16. Interpreted sea-level change based off of changes in detrital input proxies and clay indicators. This data set has been biostratigraphically dated (Golding et al., 2014). Additionally, relative sea-level curves from Davies et al. (1997) have been incorporated along the left. These inferred shoreline shifts (central) agree with that of Davies et al. 
(1997), with the exception of two additional shoreline shifts within the present data during the Griesbachian and Dienerian. Ratio values of Sc/Zr, Lu/Hf, and Zr/La are indicated by logscale along the top of the figure.

Figure 17 Idealized cross-section highlighting Montney stratigraphy from British Columbia to Alberta (west to east). The clinoform model of Montney deposition is not new, but was first proposed by Davies et al. (1997). However, this new model highlights surfaces of significant erosion, missing from earlier models. These surfaces (such as surface 1) are often associated with sequence boundaries, first described by Davies et al. (1997). Additionally, what is often referred to in Alberta as the 'basal Doig siltstone' is here shown to be equivalent to the upper Montney in British Columbia and is equivalent to chemofacies 8 to 12 . The midMontney boundary varies across provincial boundaries. Within British Columbia, the midMontney boundary corresponds to the Smithian/Spathian boundary, while in Alberta, the mid-Montney boundary occurs at the Dienerian/Smithian transition. Thinning of the upper Montney (denoted by the Smithian/Spathian boundary) eastward results in the loss of Spathian deposits in Alberta. Within this cross-section the following boundaries of interest are depicted: (1) Alberta mid-Montney sequence boundary - associated with Montney turbidites and Coquinal Dolomite Middle Member; (2) British Columbia mid-Montney sequence boundary / Alberta top-Montney - basal Doig siltstone boundary. This boundary is the Hood Creek Road Cut sequence boundary with the large Thalassinoides; (3) Unconformity below the 'Anisian wedge'; (4) boundary between the Montney and Doig phosphate zone. The rough extent of the Basal Doig siltstone (which marks the presence of Spathian deposits, chemofacies 8 to 12) in Alberta is indicated bottom right.

This article is protected by copyright. All rights reserved. 
Table 1. Summary of the variables used in PCA/cluster analysis.

Table 2. Summary table illustrating high $(>0.8)$ and low $(<-0.8)$ Pearson product-moment correlation values for certain elements. High correlation values are indicated in green; negative correlation is identified by red.

Table 3. Mineral occurrence of elements discussed in Pearce et al. (2010), who also referred to the work of Morton et al. (2005) and Pearce et al. (2005).

Table 4. X-ray diffraction (XRD) analysis for select intervals of well 2-30-070-24W5. The limit of detection varies from 0.5 to $2.0 \%$ depending on crystallinity.

Table 5. Calculated values for detrital proxy data within each chemofacies, from the type data set (16-17-083-25W6), including maximum, minimum and average values. These values were compared with the overall average values for this data set $\left(\mathrm{TiO}_{2} / \mathrm{Al}_{2} \mathrm{O}_{3}=0.0657, \mathrm{Sc} / \mathrm{Zr}=\right.$ $0.0353, \mathrm{Lu} / \mathrm{Hf}=0.0632$ and $\left.\mathrm{TiO}_{2} / \mathrm{K}_{2} \mathrm{O}=0.192\right)$. Values above the overall average appear in green; values below the overall calculated average appear in red.

Table 6. Calculated values for clay proxy data within each chemofacies from the type data set (16-17-083-25W6), including maximum, minimum and average values. These values were compared with the overall average values for this data set $(\mathrm{Ga} / \mathrm{Rb}=0.14, \mathrm{~K} / \mathrm{Rb}=$ $330.75, \mathrm{Rb} / \mathrm{Al}=0.0017, \mathrm{Cr} / \mathrm{Sc}=7.629, \mathrm{Zr} / \mathrm{La}=9.40, \mathrm{Zn} / \mathrm{Sc}=19.1453, \mathrm{~K}_{2} \mathrm{O} / \mathrm{Al}_{2} \mathrm{O}_{3}=0.347$ and $\left.\mathrm{Na}_{2} \mathrm{O} / \mathrm{Al}_{2} \mathrm{O}_{3}=0.129\right)$. Values above the overall average appear in green; values below the overall calculated average appear in red.

This article is protected by copyright. All rights reserved. 
Table 7. Calculated values for mineralogical proxy data within each chemofacies, from the type data set (16-17-083-25W6), including maximum, minimum and average values. These values were compared with the overall average values for this data set $\left(\mathrm{P}_{2} \mathrm{O}_{5} / \mathrm{Al}_{2} \mathrm{O}_{3}=0.074\right.$, $\mathrm{Cr} / \mathrm{Nb}=6.86, \mathrm{Lu} / \mathrm{Zr}=0.0016$ and $\mathrm{Cr} / \mathrm{Zr}=0.275)$. Values above the overall average appear in green; values below the overall calculated average appear in red.

Table 8. Calculated values for provenance proxy data within each chemofacies, from the type data set (16-17-083-25W6), including maximum, minimum and average values. These values were compared with the overall average values for this data set $(\mathrm{Cr} / \mathrm{Al}=0.0015, \mathrm{Ni} / \mathrm{Al}$ $=0.000812, \mathrm{Th} / \mathrm{Sc}=0.952, \mathrm{MgO} / \mathrm{Al}_{2} \mathrm{O}_{3}=0.523, \mathrm{Ti} / \mathrm{Nb}=332.45$ and $\left.\mathrm{Ti} / \mathrm{Zr}=13.58\right)$. Values above the overall average appear in green; values below the overall calculated average appear in red.

Table 9. Interpretation of each chemofacies using the average values generated in Table 5. Interpretation is based on the literature cited in the text.

\section{Supplementary Tables and Figures}

Table S1. Pearson product-moment values for well 16-17-083-25W6. Table values greater than 0.8 are highlighted in green while values below -0.8 are highlighted in red.

Table S2. Pearson product-moment values for Ursula Creek. Table values greater than 0.8 are highlighted in green while values below -0.8 are highlighted in red. 
Table S3. Pearson product-moment values for well 2-30-070-24W5. Table values greater than 0.8 are highlighted in green while values below -0.8 are highlighted in red.

Table S4. Pearson product-moment values for well 11-20-082-02W6. Table values greater than 0.8 are highlighted in green while values below -0.8 are highlighted in red.

Table S5. Pearson product-moment values for well d-48-A/94-B-9. Table values greater than 0.8 are highlighted in green while values below -0.8 are highlighted in red.

Table S6. Pearson product-moment values for well c-74-G/94-B-9. Table values greater than 0.8 are highlighted in green while values below -0.8 are highlighted in red.

Table S7. Summary of the first ten principal components used for statistically defining the chemofacies.

Fig. S1. Clay indicator profiles for well d-48-A/94-B-9. Depths are in metres. Chemofacies are numbered on the right. Simplified interpretations of concentrations are labelled at the base with arrows. For references, refer to the Elemental Indicators section in the text.

Fig. S2. Detrital indicator profiles for well d-48-A/94-B-9. Depths are in metres. Chemofacies are numbered on the right. Simplified interpretations of concentrations are labelled at the base with arrows. For references, refer to the Elemental Indicators section in the text.

This article is protected by copyright. All rights reserved. 
Fig. S3. Mineralogical indicator profiles for well d-48-A/94-B-9. Depths are in metres. Chemofacies are numbered on the right. Simplified interpretations of concentrations are labelled at the base with arrows. For references, refer to the Elemental Indicators section in the text.

Fig. S4. Provenance indicator profiles for well d-48-A/94-B-9. Depths are in metres. Chemofacies are numbered on the right. Simplified interpretations of concentrations are labelled at the base with arrows. For references, refer to the Elemental Indicators section in the text.

Fig. S5. Clay indicator profiles for well c-74-G/94-B-9. Depths are in metres. Chemofacies are numbered on the right. Simplified interpretations of concentrations are labelled at the base with arrows. For references, refer to the Elemental Indicators section in the text.

Fig. S6. Detrital indicator profiles for well c-74-G/94-B-9. Depths are in metres. Chemofacies are numbered on the right. Simplified interpretations of concentrations are labelled at the base with arrows. For references, refer to the Elemental Indicators section in the text.

Fig. S7. Mineralogical indicator profiles for well c-74-G/94-B-9. Depths are in metres. Chemofacies are numbered on the right. Simplified interpretations of concentrations are labelled at the base with arrows. For references, refer to the Elemental Indicators section in the text.

This article is protected by copyright. All rights reserved. 
Fig. S8. Provenance indicator profiles for well c-74-G/94-B-9. Depths are in metres. Chemofacies are numbered on the right. Simplified interpretations of concentrations are labelled at the base with arrows. For references, refer to the Elemental Indicators section in the text.

Fig. S9. Clay indicator profiles for well 11-20-082-02W6. Depths are in feet. Chemofacies are numbered on the right. Simplified interpretations of concentrations are labelled at the base with arrows. For references, refer to the Elemental Indicators section in the text.

Fig. S10. Detrital indicator profiles for well 11-20-082-02W6. Depths are in feet. Chemofacies are numbered on the right. Simplified interpretations of concentrations are labelled at the base with arrows. For references, refer to the Elemental Indicators section in the text.

Fig. S11. Mineralogical indicator profiles for well 11-20-082-02W6. Depths are in feet. Chemofacies are numbered on the right. Simplified interpretations of concentrations are labelled at the base with arrows. For references, refer to the Elemental Indicators section in the text.

Fig. S12. Provenance indicator profiles for well 11-20-082-02W6. Depths are in feet. Chemofacies are numbered on the right. Simplified interpretations of concentrations are labelled at the base with arrows. For references, refer to the Elemental Indicators section in the text.

This article is protected by copyright. All rights reserved. 
Fig. S13. Clay indicator profiles for well 2-30-070-24W5. Depths are in metres. Chemofacies are numbered on the right. Simplified interpretations of concentrations are labelled at the base with arrows. For references, refer to the Elemental Indicators section in the text.

Fig. S14. Detrital indicator profiles for well 2-30-070-24W5. Depths are in metres.

Chemofacies are numbered on the right. Simplified interpretations of concentrations are labelled at the base with arrows. For references, refer to the Elemental Indicators section in the text.

Fig. S15. Mineralogical indicator profiles for well 2-30-070-24W5. Depths are in metres. Chemofacies are numbered on the right. Simplified interpretations of concentrations are labelled at the base with arrows. For references, refer to the Elemental Indicators section in the text.

Fig. S16. Provenance indicator profiles for well 2-30-070-24W5. Depths are in metres. Chemofacies are numbered on the right. Simplified interpretations of concentrations are labelled at the base with arrows. For references, refer to the Elemental Indicators section in the text.

Fig. S17. Clay indicator profiles for the outcrop Ursula Creek. Depths are in metres. Chemofacies are numbered on the right. Simplified interpretations of concentrations are labelled at the base with arrows. For references, refer to the Elemental Indicators section in the text.

This article is protected by copyright. All rights reserved. 
Fig. S18. Detrital indicator profiles for the outcrop Ursula Creek. Depths are in metres. Chemofacies are numbered on the right. Simplified interpretations of concentrations are labelled at the base with arrows. For references, refer to the Elemental Indicators section in the text.

Fig. S19. Mineralogical indicator profiles for the outcrop Ursula Creek. Depths are in metres. Chemofacies are numbered on the right. Simplified interpretations of concentrations are labelled at the base with arrows. For references, refer to the Elemental Indicators section in the text.

Fig. S20. Provenance indicator profiles for the outcrop Ursula Creek. Depths are in metres. Chemofacies are numbered on the right. Simplified interpretations of concentrations are labelled at the base with arrows. For references, refer to the Elemental Indicators section in the text.

Fig. S21. Comparison of select detrital and clay indicators between wells 2-30-070-24W5 (right) and 16-17-083-25W6 (left) illustrating the identification and correlation of chemofacies in well 2-30-070-24W5.

Fig. S22. Comparison of select detrital and clay indicators between wells 11-20-082-02W6 (right) and 16-17-083-25W6 (left) illustrating the identification and correlation of chemofacies in well 11-20-082-02W6.

This article is protected by copyright. All rights reserved. 
Fig. S23. Comparison of select detrital and clay indicators between wells c-74-G/94-B-9 (right) and 16-17-083-25W6 (left) illustrating the identification and correlation of chemofacies in well c-74-G/94-B-9.

Fig. S24. Comparison of select detrital and clay indicators between wells d-48-A/94-B-9 (right) and 16-17-083-25W6 (left) illustrating the identification and correlation of chemofacies in well d-48-A/94-B-9.

Fig. S25. Comparison of select detrital and clay indicators between the outcrop Ursula Creek (right) and 16-17-083-25W6 (left) illustrating the identification and correlation of chemofacies in outcrop Ursula Creek.

Fig. S26. Litholog for well 16-17-083-25W6. See legend for explanation of symbols used.

Fig. S27. Litholog for well d-48-A/94-B-9. See legend for explanation of symbols used.

Fig. S28. Litholog for well c-74-G/94-B-9. See legend for explanation of symbols used.

Fig. S29. Litholog for the outcrop Ursula Creek.

Fig. S30. Graph of the number of clusters vs. similarity between clusters. An inflection point occurs at 12 , which is why 12 statistical divisions were chosen. The Belloy Formation, defined by Golding et al. (2014) within this study's data set, was divided out as an additional subdivision (although the division is not statistically significant). 


\begin{tabular}{ll}
\hline Category & Number of Variables \\
\hline Oxides & 10 \\
\hline Oxide Elements & 10 \\
\hline Trace Elements & 40 \\
\hline Clay Indicators & 7 \\
\hline Provenance Indicators & 5 \\
\hline Detrital Indicators & 4 \\
\hline Mineral Indicators & 6 \\
\hline Grain Size Indicators & 2 \\
\hline ALL DATA & 84 \\
\hline
\end{tabular}

This article is protected by copyright. All rights reserved. 


\begin{tabular}{|c|c|c|c|c|c|c|c|c|}
\hline Element & $\mathrm{SiO} 2$ & $\mathrm{Al} 2 \mathrm{O} 3$ & $\mathrm{TiO} 2$ & $\mathrm{~K} 2 \mathrm{O}$ & $\mathrm{CaO}$ & $\mathrm{Na} 2 \mathrm{O}$ & $\mathrm{Ta}$ & $\mathrm{Zr}$ \\
\hline \multicolumn{9}{|l|}{ Th } \\
\hline \multicolumn{9}{|l|}{$\mathrm{Ta}$} \\
\hline \multicolumn{9}{|l|}{$\mathrm{Nb}$} \\
\hline \multicolumn{9}{|l|}{$\mathrm{Rb}$} \\
\hline \multicolumn{9}{|l|}{$\mathrm{Ga}$} \\
\hline \multicolumn{9}{|l|}{ Sc } \\
\hline \multicolumn{9}{|l|}{ Co } \\
\hline \multicolumn{9}{|l|}{ Cs } \\
\hline \multicolumn{9}{|l|}{$\mathrm{Be}$} \\
\hline \multicolumn{9}{|l|}{$\mathrm{Hf}$} \\
\hline \multicolumn{9}{|l|}{$\mathrm{Zr}$} \\
\hline \multicolumn{9}{|l|}{$\mathrm{Ni}$} \\
\hline \multicolumn{9}{|l|}{$\mathrm{Ba}$} \\
\hline \multicolumn{9}{|l|}{$\mathrm{Ce}$} \\
\hline \multicolumn{9}{|l|}{$\mathrm{SiO} 2$} \\
\hline \multicolumn{9}{|l|}{$\mathrm{Al} 2 \mathrm{O3}$} \\
\hline \multicolumn{9}{|l|}{$\mathrm{TiO} 2$} \\
\hline \multicolumn{9}{|l|}{$\mathrm{K} 2 \mathrm{O}$} \\
\hline $\mathrm{MgO}$ & & & & & & & & \\
\hline
\end{tabular}

This article is protected by copyright. All rights reserved. 


\begin{tabular}{|c|c|}
\hline Element & Mineral affinity \\
\hline Si & Quartz \\
\hline Al & Clay minerals, mica, kaolinite, gibbsite, bauxite \\
\hline $\mathrm{Ti}, \mathrm{Nb}, \mathrm{Ta}$ & $\begin{array}{l}\text { heavy minerals such as rutile, anatase and Ti-bearing minerals (leucoxene and } \\
\text { ilmenite) }\end{array}$ \\
\hline Fe & Fe oxyhydroxides (geothite and hematite), ferroan dolomite, pyrite, siderite \\
\hline $\begin{array}{l}\mathrm{Ca}, \mathrm{Mn}, \mathrm{Mg} \text {, } \\
\mathrm{Sr}\end{array}$ & siderite, dolomite, calcite, clays (Mg associated with chlorite) \\
\hline $\mathrm{Na}$ & clay minerals, halite \\
\hline $\mathrm{K}, \mathrm{Rb}, \mathrm{Cs}$ & illite, mica, K-feldspar \\
\hline $\mathrm{P}$ & $\begin{array}{l}\text { clays (illite), mica, siderite (in association with } \mathrm{Fe}, \mathrm{Mn} \text { and REEs), biogenic phosphate } \\
\text { (associated with } \mathrm{U}, \mathrm{Mo}, \mathrm{Ca} \text { and } \mathrm{Ce} \text { ) }\end{array}$ \\
\hline $\mathrm{Zr}$ and $\mathrm{Hf}$ & zircon \\
\hline $\begin{array}{l}\mathrm{Co}, \mathrm{Ni}, \mathrm{Zn}, \\
\mathrm{V}, \mathrm{Cu}\end{array}$ & clay minerals and mica; Ni can be associated with Fe-oxyhydroxides \\
\hline Th & $\begin{array}{l}\text { weathered kaolinite (in association with Al, Ga and Sc), zircon, clay minerals, mica, } \\
\text { apatite }\end{array}$ \\
\hline$U$ & organics, zircon (associated with Th and $\mathrm{Zr}$ ) \\
\hline REE & $\begin{array}{l}\text { clay and mica, kaolinite or gibbsite (associated with high Al), Fe-oxyhydroxides, } \\
\text { diderite, zircon and garnet }\end{array}$ \\
\hline Sc and $\mathrm{Ga}$ & kaolinite (in association with Al) \\
\hline $\begin{array}{l}\text { Be, W, and } \\
\text { Sn }\end{array}$ & heavy minerals (beryl and cassiterite), tonstein \\
\hline $\mathrm{Ba}$ & clay and drilling fluid \\
\hline
\end{tabular}

This article is protected by copyright. All rights reserved. 


\begin{tabular}{|c|c|c|c|c|c|c|c|c|c|c|}
\hline & $\begin{array}{c}\begin{array}{c}1715.8 \\
\mathrm{~m}\end{array} \\
\end{array}$ & $\begin{array}{c}1717.5 \\
\mathrm{~m}\end{array}$ & $\begin{array}{c}1719.85 \\
\mathrm{~m}\end{array}$ & $\begin{array}{c}\begin{array}{c}1721.5 \\
\mathrm{~m}\end{array} \\
\end{array}$ & $\begin{array}{c}1723.86 \\
\mathrm{~m}\end{array}$ & $\begin{array}{c}1725.5 \\
\mathrm{~m}\end{array}$ & $\begin{array}{c}1727.35 \\
\mathrm{~m}\end{array}$ & $\begin{array}{c}\begin{array}{c}1728.46 \\
\mathrm{~m}\end{array} \\
\end{array}$ & $\begin{array}{c}1730.43 \\
\mathrm{~m}\end{array}$ & $\begin{array}{c}1732.1 \\
\mathrm{~m}\end{array}$ \\
\hline Mineral & (wt \%) & (wt \%) & (wt \%) & (wt \%) & (wt \%) & (wt \%) & (wt \%) & (wt \%) & (wt \%) & (wt \%) \\
\hline Quartz & 34.7 & 43.9 & 54.8 & 71.8 & 71.5 & 50.9 & 57.6 & 61.3 & 73.5 & 42.4 \\
\hline Dolomite & 21.7 & 18.2 & 11.3 & 12.4 & 10.2 & 15.1 & 12.8 & 11.9 & 0.6 & 48.6 \\
\hline Microcline & 17.8 & 8.1 & 15.1 & 6.3 & 5.1 & 13.1 & 10.1 & 8.9 & 1.1 & - \\
\hline Muscovite & 9.1 & 12.4 & 5.2 & 1.9 & 3.2 & 6.7 & 5.4 & 1.6 & 2.0 & - \\
\hline Calcite & 3.5 & 5.8 & 2.1 & 0.7 & 1.1 & 1.1 & 4.5 & 6.1 & 5.3 & 0.6 \\
\hline Diopside & 2.8 & 3.2 & 3.1 & 1.4 & 1.7 & 3.1 & 1.9 & 2.6 & - & - \\
\hline Albite & 2.0 & 1.5 & 1.4 & 1.4 & 2.0 & 1.7 & 2.4 & 2.7 & 0.9 & 1.0 \\
\hline Pyrite & 2.8 & 2.2 & 2.0 & 0.5 & 0.7 & 2.9 & 1.0 & 0.6 & 3.8 & 0.3 \\
\hline Clinochlore & 1.0 & 1.6 & 1.3 & 0.7 & 1.1 & 1.0 & 1.7 & 1.4 & - & - \\
\hline Ankerite & 0.9 & 0.8 & 0.9 & 0.8 & 1.0 & 0.9 & 0.9 & 1.0 & - & 2.3 \\
\hline Kaolinite & 2.0 & 0.3 & 0.8 & 0.2 & 0.3 & 1.7 & 0.3 & 0.4 & 0.3 & - \\
\hline Chlorapatite & 0.5 & 0.6 & 0.7 & 1.0 & 1.2 & 0.7 & 0.5 & 0.7 & - & - \\
\hline Kutnohorite & 0.4 & 0.7 & 0.5 & 0.4 & 0.3 & 0.5 & 0.5 & 0.5 & - & 0.8 \\
\hline Brookite & 0.4 & 0.4 & 0.4 & 0.3 & 0.3 & 0.4 & 0.3 & 0.2 & - & - \\
\hline Siderite & 0.5 & 0.3 & 0.2 & 0.2 & 0.2 & 0.3 & 0.2 & 0.2 & 1.4 & 0.4 \\
\hline Fluorapatite & - & - & - & - & - & - & - & - & 5.2 & - \\
\hline Marcasite & - & - & - & - & - & - & - & - & 5.0 & - \\
\hline $\begin{array}{l}\text { Calcite } \\
\text { magnesian }\end{array}$ & - & - & - & - & - & - & - & - & 0.9 & - \\
\hline Fluorapatite & - & - & - & - & - & - & - & - & - & 3.5 \\
\hline TOTAL & 100 & 100 & 100 & 100 & 100 & 100 & 100 & 100 & 100 & 100 \\
\hline
\end{tabular}

This article is protected by copyright. All rights reserved. 


\begin{tabular}{|c|c|c|c|c|c|}
\hline Chemofacies & & $\mathrm{Ti} / \mathrm{Al}$ & $\mathrm{Sc} / \mathrm{Zr}$ & $\mathrm{Lu} / \mathrm{Hf}$ & $\mathrm{Ti} / \mathrm{K}$ \\
\hline \multirow[t]{3}{*}{13} & $\max$ & 0.080849 & 0.043779 & 0.173555 & 0.170706 \\
\hline & $\min$ & 0.059138 & 0.005979 & 0.029456 & 0.127007 \\
\hline & avg & 0.064859 & 0.031454 & 0.092964 & 0.145504 \\
\hline \multirow[t]{3}{*}{12} & $\max$ & 0.074222 & 0.030399 & 0.084082 & 0.198194 \\
\hline & $\min$ & 0.063336 & 0.011721 & 0.039973 & 0.165484 \\
\hline & avg & 0.068147 & 0.02187 & 0.051852 & 0.179885 \\
\hline \multirow[t]{3}{*}{11} & $\max$ & 0.076006 & 0.037303 & 0.062728 & 0.18926 \\
\hline & $\min$ & 0.06199 & 0.021035 & 0.047911 & 0.161212 \\
\hline & avg & 0.070189 & 0.027035 & 0.054473 & 0.176587 \\
\hline \multirow[t]{3}{*}{10} & $\max$ & 0.068321 & 0.042413 & 0.087519 & 0.186066 \\
\hline & $\min$ & 0.063022 & 0.026862 & 0.049446 & 0.159848 \\
\hline & avg & 0.064733 & 0.033378 & 0.05982 & 0.17563 \\
\hline \multirow[t]{3}{*}{9} & $\max$ & 0.072897 & 0.039814 & 0.070306 & 0.208827 \\
\hline & $\min$ & 0.060782 & 0.024184 & 0.047167 & 0.178039 \\
\hline & avg & 0.0666 & 0.03026 & 0.054408 & 0.197164 \\
\hline \multirow[t]{3}{*}{8} & $\max$ & 0.071875 & 0.040722 & 0.078009 & 0.201467 \\
\hline & $\min$ & 0.063023 & 0.021032 & 0.047175 & 0.163489 \\
\hline & avg & 0.067303 & 0.031435 & 0.057197 & 0.178699 \\
\hline \multirow[t]{3}{*}{7} & $\max$ & 0.073922 & 0.053382 & 0.120945 & 0.243106 \\
\hline & $\min$ & 0.053016 & 0.016499 & 0.041868 & 0.169261 \\
\hline & avg & 0.063546 & 0.033181 & 0.064096 & 0.203927 \\
\hline \multirow[t]{3}{*}{6} & $\max$ & 0.07461 & 0.049462 & 0.067065 & 0.2409 \\
\hline & $\min$ & 0.062391 & 0.024333 & 0.049591 & 0.175265 \\
\hline & avg & 0.069363 & 0.033184 & 0.055683 & 0.221709 \\
\hline \multirow[t]{3}{*}{5} & $\max$ & 0.068878 & 0.057641 & 0.094791 & 0.24838 \\
\hline & $\min$ & 0.053437 & 0.030539 & 0.055284 & 0.172797 \\
\hline & avg & 0.062174 & 0.043994 & 0.06734 & 0.205108 \\
\hline \multirow[t]{3}{*}{4} & $\max$ & 0.065819 & 0.067887 & 0.074359 & 0.238807 \\
\hline & $\min$ & 0.057334 & 0.037093 & 0.056949 & 0.201989 \\
\hline & avg & 0.061495 & 0.04671 & 0.064463 & 0.21512 \\
\hline \multirow[t]{3}{*}{3} & $\max$ & 0.069375 & 0.056266 & 0.080454 & 0.239093 \\
\hline & $\min$ & 0.059928 & 0.026031 & 0.051332 & 0.206833 \\
\hline & avg & 0.066101 & 0.041434 & 0.063167 & 0.224788 \\
\hline \multirow[t]{3}{*}{2} & $\max$ & 0.06739 & 0.07577 & 0.107734 & 0.2096 \\
\hline & $\min$ & 0.055197 & 0.039477 & 0.061322 & 0.177362 \\
\hline & avg & 0.062575 & 0.052278 & 0.073085 & 0.194342 \\
\hline \multirow[t]{3}{*}{1} & $\max$ & 0.040829 & 0.064328 & 0.118158 & 0.119407 \\
\hline & $\min$ & 0.040829 & 0.064328 & 0.118158 & 0.119407 \\
\hline & avg & 0.040829 & 0.064328 & 0.118158 & 0.119407 \\
\hline
\end{tabular}

This article is protected by copyright. All rights reserved. 


\begin{tabular}{|c|c|c|c|c|c|c|c|c|c|}
\hline Chemofacies & & $\mathrm{Ga} / \mathrm{Rb}$ & $\mathrm{K} / \mathrm{Rb}$ & $\mathrm{Rb} / \mathrm{Al}$ & $\mathrm{Cr} / \mathrm{Sc}$ & $\mathrm{Zr} / \mathrm{La}$ & $\mathrm{Zn} / \mathrm{Sc}$ & $\mathrm{K} / \mathrm{Al}$ & $\mathrm{Na} / \mathrm{Al}$ \\
\hline 13 & $\max$ & 0.143721 & 447.1661 & 0.002095 & 27.0123 & 34.03326 & 256.8932 & 0.501256 & 0.208801 \\
\hline & $\min$ & 11274 & 336.8972 & 0.001549 & 9.426651 & 3.325384 & 5.362664 & 0.391936 & 0.081105 \\
\hline & avg & 0.124387 & 383.7705 & 0.001835 & 16.78576 & 8.952996 & 86.80913 & 0.447062 & 0.128345 \\
\hline \multirow[t]{3}{*}{12} & $\max$ & 0.158361 & 431.9538 & 0.001658 & 9.953695 & 17.63911 & 55.77653 & 0.395282 & 0.200057 \\
\hline & $\min$ & 0.137179 & 357.9692 & 0.001402 & 5.623236 & 3.811868 & 2.442895 & 0.358246 & 0.117733 \\
\hline & avg & 0.147251 & 394.7814 & 0.00151 & 6.68064 & 11.8819 & 6.694111 & 0.379022 & 0.145489 \\
\hline \multirow[t]{3}{*}{11} & $\max$ & 0.161331 & 429.3171 & 0.00169 & 7.216126 & 12.43012 & 47.05129 & 0.427444 & 0.165247 \\
\hline & $\min$ & 0.141334 & 337.661 & 0.001456 & 5.381372 & 7.386836 & 3.145944 & 0.363704 & 0.114875 \\
\hline & avg & 0.150456 & 401.2225 & 0.001556 & 6.291306 & 10.76913 & 14.56291 & 0.397867 & 0.144111 \\
\hline \multirow[t]{3}{*}{10} & $\max$ & 0.161511 & 406.3616 & 0.001606 & 6.886009 & 11.44016 & 88.21825 & 0.394261 & 0.138733 \\
\hline & $\min$ & 0.147946 & 348.6106 & 0.001379 & 4.760351 & 5.077812 & 3.897445 & 0.345093 & 0.081716 \\
\hline & avg & 0.154281 & 387.0522 & 0.001498 & 5.86343 & 9.482 & 19.74178 & 0.369222 & 0.126461 \\
\hline \multirow[t]{3}{*}{9} & $\max$ & 0.156148 & 365.6342 & 0.001775 & 8.013681 & 12.59312 & 72.27645 & 0.357709 & 0.164609 \\
\hline & $\min$ & 0.14279 & 310.5874 & 0.001454 & 4.635608 & 7.80944 & 3.236714 & 0.321905 & 0.119659 \\
\hline & avg & 0.148344 & 336.7473 & 0.001578 & 6.207366 & 10.40401 & 21.79454 & 0.337878 & 0.13732 \\
\hline \multirow[t]{3}{*}{8} & $\max$ & 0.169069 & 410.8626 & 0.001877 & 10.79284 & 13.55448 & 121.1066 & 0.40682 & 0.17951 \\
\hline & $\min$ & 0.136376 & 310.1469 & 0.001458 & 5.274246 & 4.878766 & 2.680357 & 0.35415 & 0.104558 \\
\hline & avg & 0.148075 & 356.5648 & 0.001667 & 7.379145 & 9.950678 & 34.14526 & 0.377362 & 0.135034 \\
\hline \multirow[t]{3}{*}{7} & $\max$ & 0.155409 & 380.0742 & 0.001757 & 6.860339 & 13.8056 & 49.99996 & 0.374848 & 0.242245 \\
\hline & $\min$ & 0.1358 & 257.8504 & 0.001459 & 4.866671 & 3.586812 & 2.722726 & 0.247776 & 0.1242 \\
\hline & avg & 0.146077 & 305.9059 & 0.001622 & 5.982422 & 8.915995 & 9.136538 & 0.315692 & 0.158982 \\
\hline \multirow[t]{3}{*}{6} & $\max$ & 0.147924 & 349.1123 & 0.00185 & 7.454226 & 11.99854 & 102.0715 & 0.391681 & 0.183252 \\
\hline & $\min$ & 0.128235 & 261.1168 & 0.001508 & 5.726949 & 6.983901 & 2.207871 & 0.295087 & 0.102822 \\
\hline & avg & 0.138522 & 294.5231 & 0.001675 & 6.469519 & 10.26135 & 7.895225 & 0.31384 & 0.147736 \\
\hline \multirow[t]{2}{*}{5} & $\max$ & 0.158948 & 322.8516 & 0.001827 & 7.189465 & 10.25548 & 33.83281 & 0.321791 & 0.208736 \\
\hline & $\min$ & 0.125228 & 257.0505 & 0.001516 & 4.887892 & 5.392277 & 3.200026 & 0.27117 & 0.087282 \\
\hline
\end{tabular}

This article is protected by copyright. All rights reserved. 


\begin{tabular}{|c|c|c|c|c|c|c|c|c|c|}
\hline & avg & 0.137639 & 287.0996 & 0.001665 & 6.030078 & 7.830425 & 7.40361 & 0.303945 & 0.129007 \\
\hline \multirow[t]{3}{*}{4} & $\max$ & 0.148307 & 277.1773 & 0.001821 & 6.681185 & 9.828208 & 12.21662 & 0.296667 & 0.141206 \\
\hline & $\min$ & 0.127914 & 247.7709 & 0.001632 & 5.15183 & 6.630656 & 2.376812 & 0.272759 & 0.089285 \\
\hline & avg & 0.133818 & 260.103 & 0.001725 & 5.999295 & 8.288536 & 6.640891 & 0.285709 & 0.11043 \\
\hline \multirow[t]{3}{*}{3} & $\max$ & 0.143752 & 313.7154 & 0.00189 & 8.334991 & 11.43834 & 23.26896 & 0.30733 & 0.173565 \\
\hline & $\min$ & 0.118853 & 236.9108 & 0.001496 & 5.616258 & 6.609984 & 2.241635 & 0.281845 & 0.074249 \\
\hline & avg & 0.127163 & 258.9895 & 0.001789 & 6.690059 & 8.627507 & 9.621217 & 0.29415 & 0.097089 \\
\hline \multirow[t]{3}{*}{2} & $\max$ & 0.131944 & 298.7012 & 0.001862 & 10.64945 & 9.230741 & 15.66155 & 0.33304 & 0.085097 \\
\hline & $\min$ & 0.113769 & 262.1804 & 0.001695 & 6.436096 & 4.89438 & 1.910621 & 0.303859 & 0.046013 \\
\hline & avg & 0.121041 & 284.3407 & 0.001777 & 7.147973 & 7.126561 & 5.578249 & 0.322007 & 0.066654 \\
\hline \multirow[t]{3}{*}{1} & $\max$ & 0.152673 & 262.0636 & 0.002047 & 83.4203 & 1.287697 & 3.344827 & 0.341931 & 0.122736 \\
\hline & $\min$ & 0.152673 & 262.0636 & 0.002047 & 83.4203 & 1.287697 & 3.344827 & 0.341931 & 0.122736 \\
\hline & avg & 0.152673 & 262.0636 & 0.002047 & 83.4203 & 1.287697 & 3.344827 & 0.341931 & 0.122736 \\
\hline
\end{tabular}

This article is protected by copyright. All rights reserved. 


\begin{tabular}{|c|c|c|c|c|c|}
\hline Chemofacies & & $\mathrm{P} 203 / \mathrm{Al} 2 \mathrm{O} 3$ & $\mathrm{Cr} / \mathrm{Nb}$ & $\mathrm{Lu} / \mathrm{Zr}$ & $\mathrm{Cr} / \mathrm{Zr}$ \\
\hline \multirow[t]{3}{*}{13} & $\max$ & 2.36943706 & 30.15989 & 0.004026 & 1.000416 \\
\hline & $\min$ & 0.03037241 & 7.493004 & 0.000711 & 0.07288 \\
\hline & avg & 0.52630791 & 17.57344 & 0.002212 & 0.538475 \\
\hline \multirow[t]{3}{*}{12} & $\max$ & 1.36807648 & 7.943239 & 0.002026 & 0.214815 \\
\hline & $\min$ & 0.02091007 & 4.533239 & 0.000977 & 0.085984 \\
\hline & avg & 0.10384847 & 5.1276 & 0.001343 & 0.143382 \\
\hline \multirow[t]{3}{*}{11} & $\max$ & 0.07377165 & 5.623304 & 0.001688 & 0.211382 \\
\hline & $\min$ & 0.01811236 & 4.107049 & 0.001226 & 0.134706 \\
\hline & avg & 0.03213233 & 4.562836 & 0.001425 & 0.169215 \\
\hline \multirow[t]{3}{*}{10} & $\max$ & 0.04308528 & 5.175084 & 0.002334 & 0.217686 \\
\hline & $\min$ & 0.01845087 & 4.220701 & 0.001251 & 0.165229 \\
\hline & avg & 0.02669023 & 4.602506 & 0.001551 & 0.19396 \\
\hline \multirow[t]{3}{*}{9} & $\max$ & 0.0303379 & 5.624254 & 0.001886 & 0.258933 \\
\hline & $\min$ & 0.01595749 & 4.372693 & 0.001228 & 0.145316 \\
\hline & avg & 0.01931425 & 4.820874 & 0.001442 & 0.18593 \\
\hline \multirow[t]{3}{*}{8} & $\max$ & 0.16003218 & 9.515539 & 0.002052 & 0.394119 \\
\hline & $\min$ & 0.01197805 & 4.48655 & 0.001272 & 0.128549 \\
\hline & avg & 0.03224329 & 5.997805 & 0.001532 & 0.232964 \\
\hline \multirow[t]{3}{*}{7} & $\max$ & 0.1059192 & 6.692056 & 0.00328 & 0.302098 \\
\hline & $\min$ & 0.01863884 & 4.499245 & 0.001084 & 0.103786 \\
\hline & avg & 0.03880327 & 5.303066 & 0.001662 & 0.194837 \\
\hline \multirow[t]{3}{*}{6} & $\max$ & 0.04269826 & 5.897517 & 0.001705 & 0.31278 \\
\hline & $\min$ & 0.01734135 & 4.57523 & 0.00123 & 0.162611 \\
\hline & avg & 0.02498563 & 5.07693 & 0.001408 & 0.214048 \\
\hline \multirow[t]{3}{*}{5} & $\max$ & 0.04443363 & 6.289217 & 0.002503 & 0.339965 \\
\hline & $\min$ & 0.01384167 & 4.527507 & 0.001419 & 0.186581 \\
\hline & avg & 0.02240069 & 5.387552 & 0.001737 & 0.264026 \\
\hline \multirow[t]{3}{*}{4} & $\max$ & 0.01719659 & 6.095687 & 0.00202 & 0.361694 \\
\hline & $\min$ & 0.01202611 & 4.76272 & 0.001496 & 0.204941 \\
\hline & avg & 0.01452501 & 5.393587 & 0.001709 & 0.279008 \\
\hline \multirow[t]{3}{*}{3} & $\max$ & 0.02954884 & 6.688537 & 0.002132 & 0.329148 \\
\hline & $\min$ & 0.01272907 & 4.693517 & 0.001284 & 0.166474 \\
\hline & avg & 0.01623657 & 5.717874 & 0.001641 & 0.273501 \\
\hline \multirow[t]{3}{*}{2} & $\max$ & 0.02746657 & 9.970311 & 0.002806 & 0.569048 \\
\hline & $\min$ & 0.01136381 & 6.134519 & 0.001482 & 0.271479 \\
\hline & avg & 0.01511607 & 6.895471 & 0.001821 & 0.372473 \\
\hline \multirow[t]{3}{*}{1} & $\max$ & 0.14226455 & 125.4367 & 0.002883 & 5.36628 \\
\hline & $\min$ & 0.14226455 & 125.4367 & 0.002883 & 5.36628 \\
\hline & avg & 0.14226455 & 125.4367 & 0.002883 & 5.36628 \\
\hline
\end{tabular}

This article is protected by copyright. All rights reserved. 


\begin{tabular}{|c|c|c|c|c|c|c|c|}
\hline Chemofacies & & $\mathrm{Cr} / \mathrm{Al}$ & $\mathrm{Ni} / \mathrm{Al}$ & $\mathrm{Th} / \mathrm{Sc}$ & $\mathrm{Mg} / \mathrm{Al}$ & $\mathrm{Ti} / \mathrm{Nb}$ & $\mathrm{Ti} / \mathrm{Zr}$ \\
\hline \multirow[t]{3}{*}{13} & $\max$ & 0.0062634 & 0.003836 & 1.83846 & 2.9647 & 381.107 & 14.24579 \\
\hline & $\min$ & 0.00183892 & 0.000379 & 0.736019 & 0.327647 & 344.0334 & 3.628724 \\
\hline & avg & 0.00352918 & 0.002332 & 0.930637 & 1.052833 & 361.2772 & 10.80156 \\
\hline \multirow[t]{3}{*}{12} & $\max$ & 0.00156774 & 0.001385 & 1.565226 & 1.668002 & 385.6654 & 12.55644 \\
\hline & $\min$ & 0.0009492 & 0.000179 & 1.05759 & 0.187812 & 334.4731 & 6.367101 \\
\hline & avg & 0.00110512 & 0.000719 & 1.17332 & 0.547279 & 356.9861 & 10.01036 \\
\hline \multirow[t]{3}{*}{11} & $\max$ & 0.00124826 & 0.001443 & 1.14847 & 2.044979 & 352.8925 & 15.16116 \\
\hline & $\min$ & 0.00098372 & 0.000424 & 0.869347 & 0.27982 & 304.4002 & 10.17989 \\
\hline & avg & 0.00110716 & 0.000867 & 1.04351 & 0.479136 & 326.6818 & 12.12023 \\
\hline \multirow[t]{3}{*}{10} & $\max$ & 0.00112522 & 0.00102 & 1.056328 & 2.114342 & 336.2982 & 15.57039 \\
\hline & $\min$ & 0.00097965 & 0.000417 & 0.720012 & 0.235856 & 306.8697 & 11.75176 \\
\hline & avg & 0.00104771 & 0.000669 & 0.93533 & 0.570821 & 321.9305 & 13.57095 \\
\hline \multirow[t]{3}{*}{9} & $\max$ & 0.00130002 & 0.001418 & 1.108614 & 1.018683 & 344.772 & 15.12734 \\
\hline & $\min$ & 0.00103571 & 0.000615 & 0.777588 & 0.254361 & 295.1303 & 10.88209 \\
\hline & avg & 0.00113099 & 0.00091 & 0.978671 & 0.464452 & 321.07 & 12.33868 \\
\hline \multirow[t]{3}{*}{8} & $\max$ & 0.00197769 & 0.001555 & 1.274315 & 2.546412 & 368.6934 & 15.66317 \\
\hline & $\min$ & 0.00106367 & 0.000396 & 0.790063 & 0.184036 & 315.0913 & 9.330922 \\
\hline & avg & 0.00134462 & 0.000885 & 1.039495 & 0.453648 & 337.5308 & 13.07144 \\
\hline \multirow[t]{3}{*}{7} & $\max$ & 0.00126011 & 0.000698 & 1.230906 & 1.650217 & 379.5571 & 14.75287 \\
\hline & $\min$ & 0.00101253 & 0.000466 & 0.690601 & 0.275305 & 286.5369 & 7.520041 \\
\hline & avg & 0.00112946 & 0.000577 & 0.96342 & 0.616601 & 336.803 & 12.20157 \\
\hline \multirow[t]{3}{*}{6} & $\max$ & 0.00137507 & 0.001177 & 1.149434 & 1.012248 & 342.0687 & 18.46911 \\
\hline & $\min$ & 0.00116471 & 0.000457 & 0.823138 & 0.22756 & 297.907 & 10.782 \\
\hline & avg & 0.00124966 & 0.000602 & 0.920702 & 0.379105 & 318.5856 & 13.37896 \\
\hline \multirow[t]{3}{*}{5} & $\max$ & 0.00128589 & 0.000721 & 0.954107 & 3.140037 & 335.6338 & 19.16005 \\
\hline & $\min$ & 0.00107518 & 0.000306 & 0.679658 & 0.192336 & 284.6911 & 11.97982 \\
\hline & avg & 0.00118573 & 0.000513 & 0.831798 & 0.668878 & 318.8622 & 15.57781 \\
\hline \multirow[t]{3}{*}{4} & $\max$ & 0.00127369 & 0.000623 & 0.930612 & 0.605206 & 344.8781 & 20.46371 \\
\hline & $\min$ & 0.00111979 & 0.000437 & 0.671276 & 0.244649 & 307.79 & 13.24425 \\
\hline & avg & 0.00116571 & 0.000498 & 0.834602 & 0.354241 & 322.2233 & 16.63752 \\
\hline \multirow[t]{3}{*}{3} & $\max$ & 0.00146115 & 0.000681 & 1.11241 & 0.652266 & 347.6538 & 19.04447 \\
\hline & $\min$ & 0.00117232 & 0.000435 & 0.753515 & 0.199414 & 313.157 & 11.10733 \\
\hline & avg & 0.00129579 & 0.000553 & 0.912867 & 0.269725 & 329.9038 & 15.76012 \\
\hline \multirow[t]{3}{*}{2} & $\max$ & 0.001939 & 0.000816 & 0.919536 & 2.277989 & 368.5659 & 24.7 \\
\hline & $\min$ & 0.00129262 & 0.000109 & 0.75019 & 0.169892 & 302.3913 & 14.80423 \\
\hline & avg & 0.00140523 & 0.000568 & 0.82467 & 0.353145 & 346.8148 & 18.64866 \\
\hline \multirow[t]{3}{*}{1} & $\max$ & 0.02554976 & 0.000939 & 0.919344 & 0.315262 & 227.0059 & 9.711491 \\
\hline & $\min$ & 0.02554976 & 0.000939 & 0.919344 & 0.315262 & 227.0059 & 9.711491 \\
\hline & avg & 0.02554976 & 0.000939 & 0.919344 & 0.315262 & 227.0059 & 9.711491 \\
\hline
\end{tabular}

This article is protected by copyright. All rights reserved. 


\begin{tabular}{|c|c|c|c|c|c|c|}
\hline Chemofacies & Provenance signal & Clay Content & Detrital input & Mineralogy & Formation & $\begin{array}{l}\text { Relative Sea } \\
\text { Level }\end{array}$ \\
\hline 13 & $\begin{array}{l}\text {-igneous, } \\
\text { mafic/ultramafic } \\
\text { sediment input } \\
\text {-submature sediment }\end{array}$ & $\begin{array}{l}\text { lower than average clay } \\
\text { content } \\
\text {-higher than average } \\
\text { chlorite and illite } \\
\text {-lower than average } \\
\text { smectite and kaolinite } \\
\text { content }\end{array}$ & $\begin{array}{l}\text {-Low detrital } \\
\text { input } \\
\text {-High pelagic } \\
\text { input } \\
\text {-Weathered } \\
\text { material and } \\
\text { clays present }\end{array}$ & $\begin{array}{l}\text {-high } \\
\text { Phosphate } \\
\text {-high heavy } \\
\text { mineral } \\
\text { content } \\
\text { (garnet, spinel, } \\
\text { rutile) }\end{array}$ & Doig & $\begin{array}{l}\text { Higher than } \\
\text { average, } \\
\text { Sharp sea level } \\
\text { rise }\end{array}$ \\
\hline 12 & $\begin{array}{l}\text {-igneous, felsic } \\
\text { sediment input } \\
\text {-dolomite present } \\
\text {-mature sediment }\end{array}$ & $\begin{array}{l}\text { lower than average clay } \\
\text { content } \\
\text {-higher than average } \\
\text { smectite and kaolinite } \\
\text {-lower than average } \\
\text { chlorite and illite content }\end{array}$ & $\begin{array}{l}\text {-high detrital } \\
\text { input with } \\
\text { sediment } \\
\text { recycling } \\
\text {-high continental } \\
\text { input and influx } \\
\text { of weathered } \\
\text { material }\end{array}$ & $\begin{array}{l}\text {-high } \\
\text { phosphate } \\
\text {-minor heavy } \\
\text { mineral } \\
\text { content }\end{array}$ & Montney & $\begin{array}{l}\text { Lower than } \\
\text { average, sea level } \\
\text { fall }\end{array}$ \\
\hline 11 & $\begin{array}{l}\text {-mature sediment } \\
\text { with mixed } \\
\text { mafic/felsic } \\
\text { signature }\end{array}$ & $\begin{array}{l}\text { lower than average clay } \\
\text { content } \\
\text {-higher than average } \\
\text { smectite and kaolinite } \\
\text {-lower than average } \\
\text { chlorite and illite content }\end{array}$ & $\begin{array}{l}\text {-high detrital } \\
\text { input with } \\
\text { sediment } \\
\text { recycling } \\
\text {-high continental } \\
\text { input and influx } \\
\text { of weathered } \\
\text { material }\end{array}$ & $\begin{array}{l}\text {-low } \\
\text { phosphate } \\
\text {-minor heavy } \\
\text { mineral } \\
\text { content }\end{array}$ & Montney & $\begin{array}{l}\text { Lower than } \\
\text { average, sharp } \\
\text { sea level fall }\end{array}$ \\
\hline 10 & $\begin{array}{l}\text {-dolomite present } \\
\text {-low mafic/felsic } \\
\text { signature } \\
\text {-submature sediment }\end{array}$ & $\begin{array}{l}\text { lower than average clay } \\
\text { content } \\
\text {-higher than average } \\
\text { kaolinite } \\
\text {-lower than average }\end{array}$ & $\begin{array}{l}\text {-minor detrital } \\
\text { input with } \\
\text { sediment } \\
\text { recycling } \\
\text { - continental }\end{array}$ & $\begin{array}{l}\text {-low } \\
\text { phosphate } \\
\text {-minor heavy } \\
\text { mineral } \\
\text { content }\end{array}$ & Montney & $\begin{array}{l}\text { Higher than } \\
\text { average, sea level } \\
\text { rise }\end{array}$ \\
\hline
\end{tabular}

This article is protected by copyright. All rights reserved. 


\begin{tabular}{|c|c|c|c|c|c|c|}
\hline & & $\begin{array}{l}\text { chlorite, illite and smectite } \\
\text { content }\end{array}$ & $\begin{array}{l}\text { input and } \\
\text { weathered } \\
\text { material present }\end{array}$ & & & \\
\hline 9 & $\begin{array}{l}\text {-mature sediment } \\
\text { with mixed } \\
\text { mafic/felsic } \\
\text { signature }\end{array}$ & $\begin{array}{l}\text { lower than average clay } \\
\text { content } \\
\text {-higher than average } \\
\text { kaolinite and smectite } \\
\text {-lower than average } \\
\text { chlorite and illite content }\end{array}$ & $\begin{array}{l}\text {-high detrital } \\
\text { input } \\
\text {-high continental } \\
\text { input with } \\
\text { sediment } \\
\text { recycling } \\
\text {-low amounts of } \\
\text { weathered } \\
\text { material/clay }\end{array}$ & $\begin{array}{l}\text {-low } \\
\text { phosphate } \\
\text {-minor heavy } \\
\text { mineral } \\
\text { content }\end{array}$ & Montney & $\begin{array}{l}\text { Lower than } \\
\text { average, sea level } \\
\text { fall }\end{array}$ \\
\hline 8 & $\begin{array}{l}\text {-mature sediment } \\
\text { with mixed } \\
\text { ultramafic/felsic, } \\
\text { igneous signature }\end{array}$ & $\begin{array}{l}\text { lower than average clay } \\
\text { content } \\
\text {-higher than average } \\
\text { smectite and kaolinite } \\
\text {-lower than average } \\
\text { chlorite and illite content }\end{array}$ & $\begin{array}{l}\text {--high detrital } \\
\text { input with } \\
\text { sediment } \\
\text { recycling } \\
\text {-high continental } \\
\text { input and influx } \\
\text { of weathered } \\
\text { material }\end{array}$ & $\begin{array}{l}\text {-low } \\
\text { phosphate } \\
\text {-minor heavy } \\
\text { mineral } \\
\text { content }\end{array}$ & Montney & $\begin{array}{l}\text { Lower than } \\
\text { average, rising } \\
\text { sea level }\end{array}$ \\
\hline 7 & $\begin{array}{l}\text {-igneous, felsic } \\
\text { sediment input } \\
\text {-dolomite present } \\
\text {-mature sediment }\end{array}$ & $\begin{array}{l}\text { higher than average clay } \\
\text { content } \\
\text {-higher than average } \\
\text { smectite and kaolinite } \\
\text {-lower than average } \\
\text { chlorite and illite content }\end{array}$ & $\begin{array}{l}\text {-Low detrital } \\
\text { input with some } \\
\text { evidence of } \\
\text { sediment } \\
\text { recycling } \\
\text {-High pelagic } \\
\text { input } \\
\text {-low amounts of } \\
\text { weathered }\end{array}$ & $\begin{array}{l}\text {-low } \\
\text { phosphate } \\
\text {-low heavy } \\
\text { mineral } \\
\text { content } \\
\text { (garnet } \\
\text { present) }\end{array}$ & Montney & $\begin{array}{l}\text { Higher than } \\
\text { average, sharp } \\
\text { rise, then fall }\end{array}$ \\
\hline
\end{tabular}

This article is protected by copyright. All rights reserved. 


\begin{tabular}{|c|c|c|c|c|c|c|}
\hline 6 & $\begin{array}{l}\text {-mixed felsic/mafic } \\
\text { signatures (low } \\
\text { signal strength) } \\
\text {-submature sediment }\end{array}$ & $\begin{array}{l}\text { lower than average clay } \\
\text { content } \\
\text {-higher than average } \\
\text { smectite and illite } \\
\text {-lower than average } \\
\text { chlorite and kaolinite } \\
\text { content }\end{array}$ & $\begin{array}{l}\text {-high detrital } \\
\text { input } \\
\text {-high continental } \\
\text { input with } \\
\text { sediment } \\
\text { recycling } \\
\text {-low amounts of } \\
\text { weathered } \\
\text { material/clay }\end{array}$ & $\begin{array}{l}\text {-low } \\
\text { phosphate } \\
\text {-minor heavy } \\
\text { mineral } \\
\text { content }\end{array}$ & Montney & $\begin{array}{l}\text { Lower than } \\
\text { average, sea level } \\
\text { fall }\end{array}$ \\
\hline 5 & $\begin{array}{l}\text {-submature sediment } \\
\text { with dolomite } \\
\text { present } \\
\text {-mixed felsic/mafic } \\
\text { signatures (low } \\
\text { signal strength) }\end{array}$ & $\begin{array}{l}\text { higher than average clay } \\
\text { content } \\
\text {-higher than average } \\
\text { smectite and illite } \\
\text {-lower than average } \\
\text { chlorite and kaolinite } \\
\text { content }\end{array}$ & $\begin{array}{l}\text {-low detrital } \\
\text { input and } \\
\text { sediment } \\
\text { recycling } \\
\text {-high pelagic } \\
\text { input } \\
\text {-low amounts of } \\
\text { weathered } \\
\text { material }\end{array}$ & $\begin{array}{l}\text {-low } \\
\text { phosphate } \\
\text {-low heavy } \\
\text { mineral } \\
\text { content } \\
\text { (garnet } \\
\text { present) }\end{array}$ & Montney & $\begin{array}{l}\text { Higher than } \\
\text { average, rise and } \\
\text { fall }\end{array}$ \\
\hline 4 & $\begin{array}{l}\text {-immature sediment } \\
\text { with mixed } \\
\text { mafic/felsic } \\
\text { signature (low signal } \\
\text { strength) }\end{array}$ & $\begin{array}{l}\text { higher than average clay } \\
\text { content } \\
\text {-higher than average illite } \\
\text {-lower than average } \\
\text { chlorite, smectite and } \\
\text { kaolinite content }\end{array}$ & $\begin{array}{l}\text {-low detrital } \\
\text { input and } \\
\text { sediment } \\
\text { recycling } \\
\text {-high pelagic } \\
\text { input } \\
\text {-low amounts of } \\
\text { weathered }\end{array}$ & $\begin{array}{l}\text {-low } \\
\text { phosphate } \\
\text {-low heavy } \\
\text { mineral } \\
\text { content } \\
\text { (garnet and } \\
\text { spinel } \\
\text { present) }\end{array}$ & Montney & $\begin{array}{l}\text { Higher than } \\
\text { average, falling }\end{array}$ \\
\hline
\end{tabular}

This article is protected by copyright. All rights reserved. 


\begin{tabular}{|c|c|c|c|c|c|c|}
\hline 3 & $\begin{array}{l}\text {-immature sediment } \\
\text { with mixed } \\
\text { mafic/felsic } \\
\text { signature (low signal } \\
\text { strength) }\end{array}$ & $\begin{array}{l}\text { higher than average clay } \\
\text { content } \\
\text {-higher than average illite } \\
\text {-lower than average } \\
\text { chlorite, smectite and } \\
\text { kaolinite content }\end{array}$ & $\begin{array}{l}\text {-mixed detrital } \\
\text { and pelagic input } \\
\text {-low sediment } \\
\text { recycling, } \\
\text { continental } \\
\text { material or } \\
\text { weathered } \\
\text { material }\end{array}$ & $\begin{array}{l}\text {-low } \\
\text { phosphate } \\
\text {-low heavy } \\
\text { mineral } \\
\text { content } \\
\text { (garnet } \\
\text { present) }\end{array}$ & Montney & $\begin{array}{l}\text { Lower than } \\
\text { average, rising }\end{array}$ \\
\hline 2 & $\begin{array}{l}\text {-igneous input, } \\
\text { mixed mafic/felsic } \\
\text { signature } \\
\text {-immature sediment }\end{array}$ & $\begin{array}{l}\text { higher than average clay } \\
\text { content } \\
\text {-higher than average illite } \\
\text {-lower than average } \\
\text { chlorite, smectite and } \\
\text { kaolinite content }\end{array}$ & $\begin{array}{l}\text {-low detrital } \\
\text { input and } \\
\text { sediment } \\
\text { recycling } \\
\text {-high pelagic } \\
\text { input } \\
\text {-low amounts of } \\
\text { weathered } \\
\text { material }\end{array}$ & $\begin{array}{l}\text {-low } \\
\text { phosphate } \\
\text {-high heavy } \\
\text { mineral } \\
\text { content } \\
\text { (spinel, garnet, } \\
\text { rutile) }\end{array}$ & Montney & $\begin{array}{l}\text {-higher than } \\
\text { average but } \\
\text { falling }\end{array}$ \\
\hline 1 & $\begin{array}{l}\text { mafic/ultramafic } \\
\text { input } \\
\text {-sediments } \\
\text { submature }\end{array}$ & $\begin{array}{l}\text {-higher than average clay } \\
\text { content } \\
\text {-higher than average } \\
\text { chlorite and illite } \\
\text {-lower than average } \\
\text { smectite and kaolinite } \\
\text { content }\end{array}$ & $\begin{array}{l}\text {-low detrital } \\
\text { input and } \\
\text { sediment } \\
\text { recycling } \\
\text {-high pelagic } \\
\text { input } \\
\text {-some } \\
\text { weathered } \\
\text { material present }\end{array}$ & $\begin{array}{l}\text {-high } \\
\text { Phosphate } \\
\text {-high heavy } \\
\text { mineral } \\
\text { content } \\
\text { (garnet, spinel, } \\
\text { rutile) }\end{array}$ & Belloy & $\begin{array}{l}\text { Higher than } \\
\text { average }\end{array}$ \\
\hline
\end{tabular}

This article is protected by copyright. All rights reserved. 


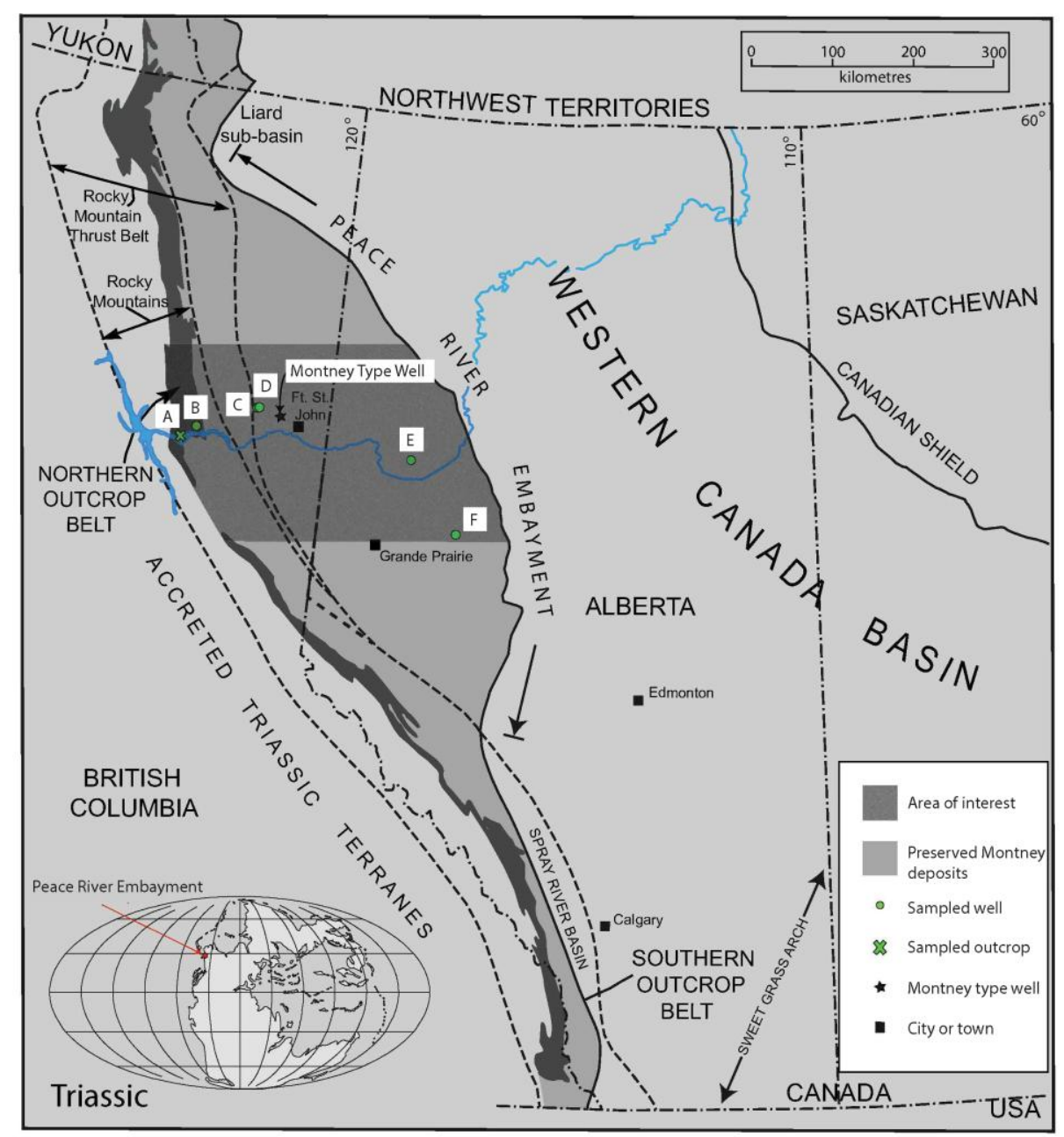

This article is protected by copyright. All rights reserved. 


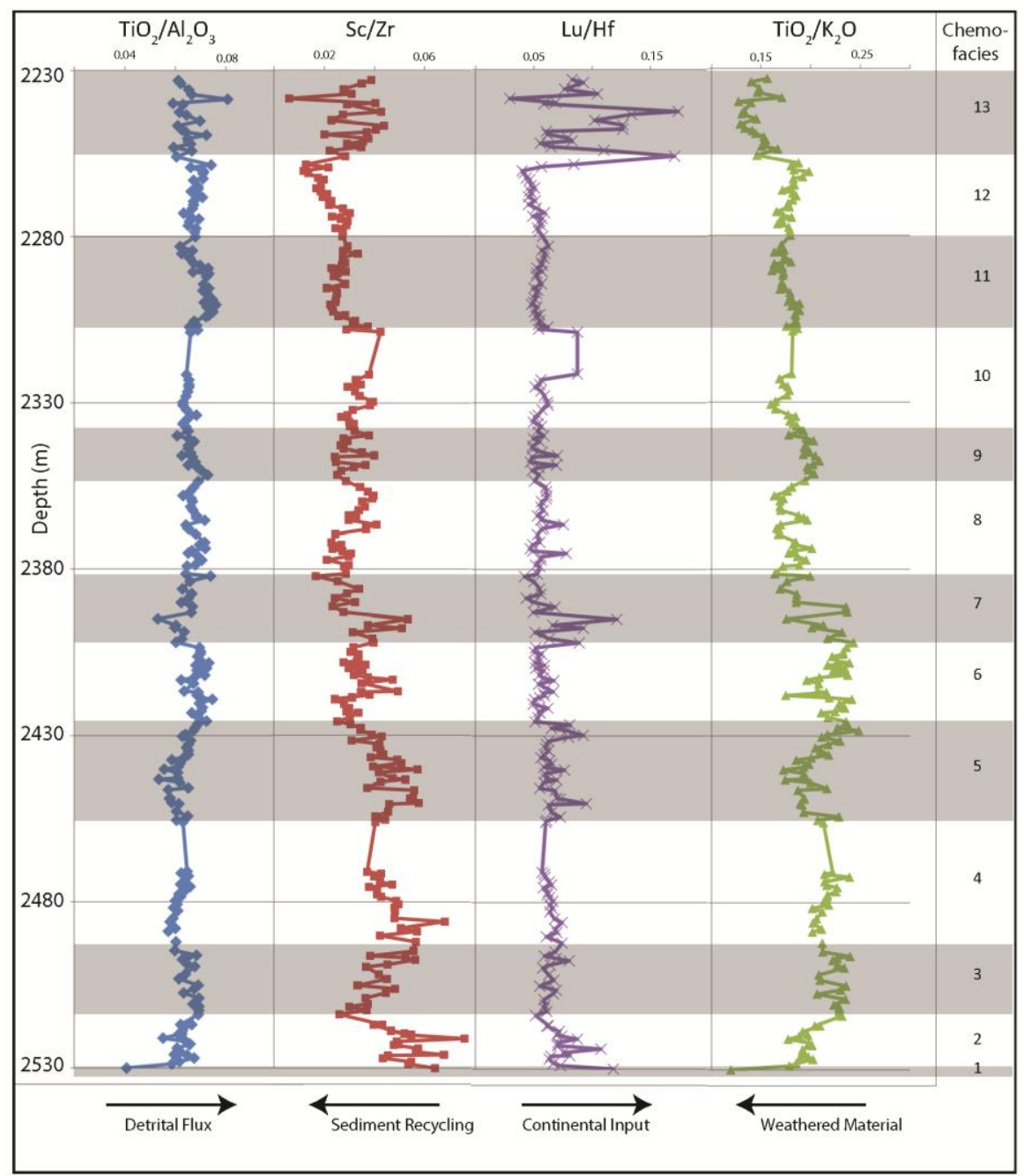

This article is protected by copyright. All rights reserved. 


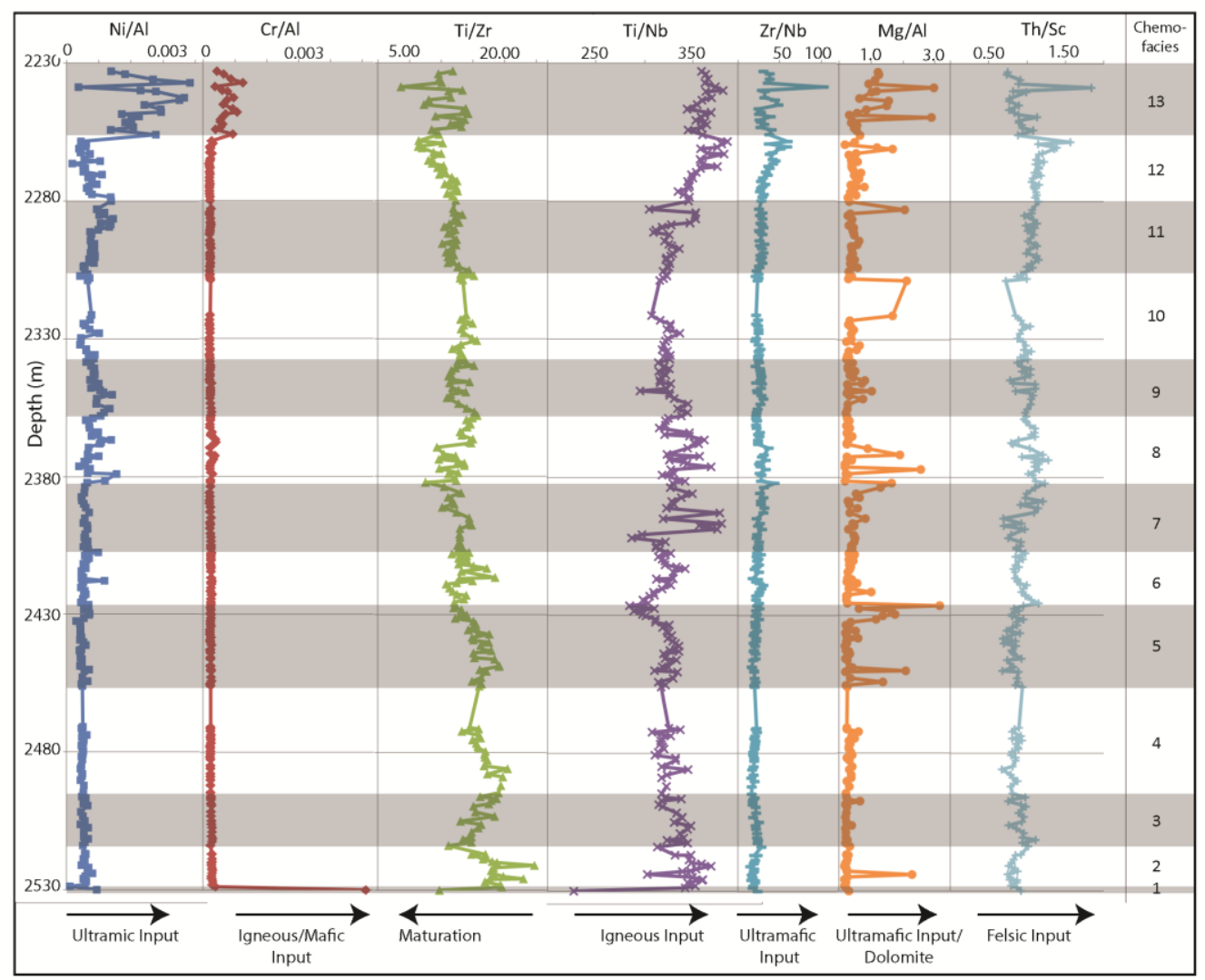

This article is protected by copyright. All rights reserved. 


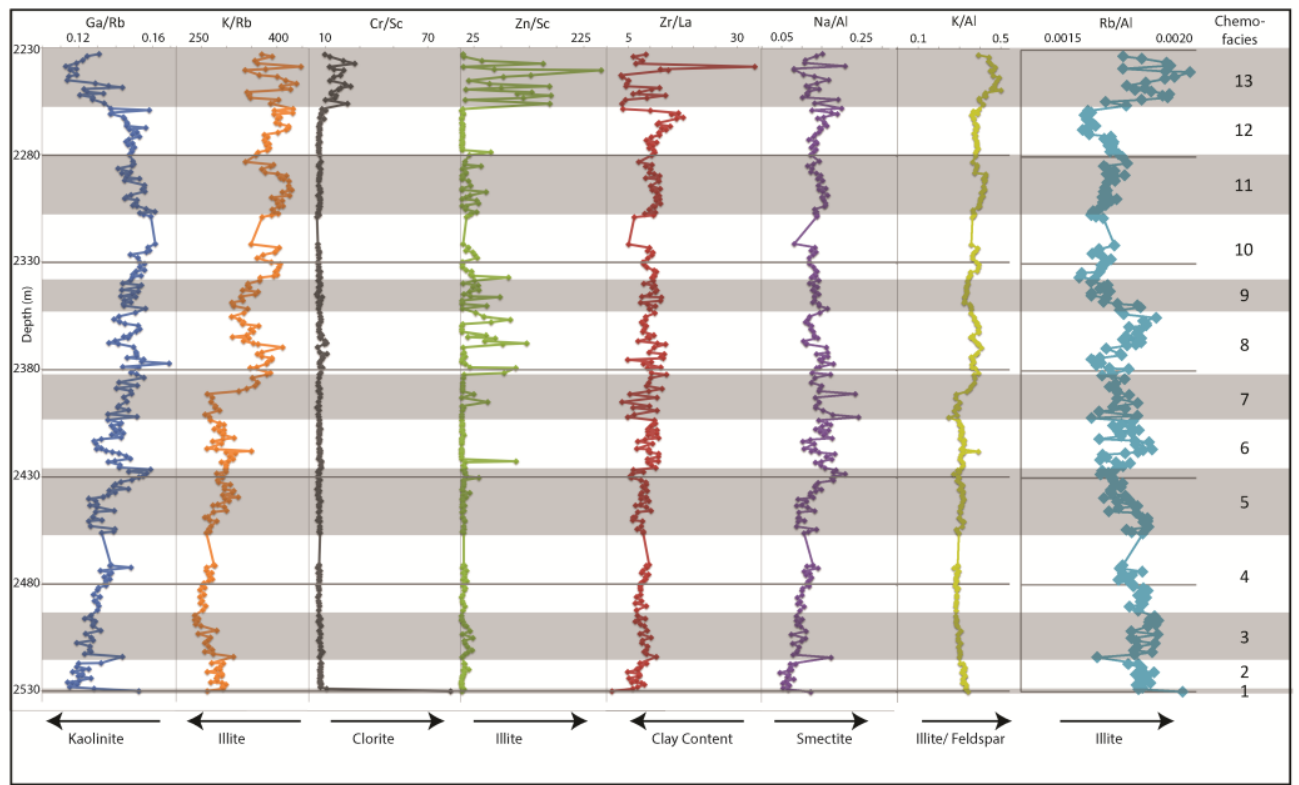

This article is protected by copyright. All rights reserved. 


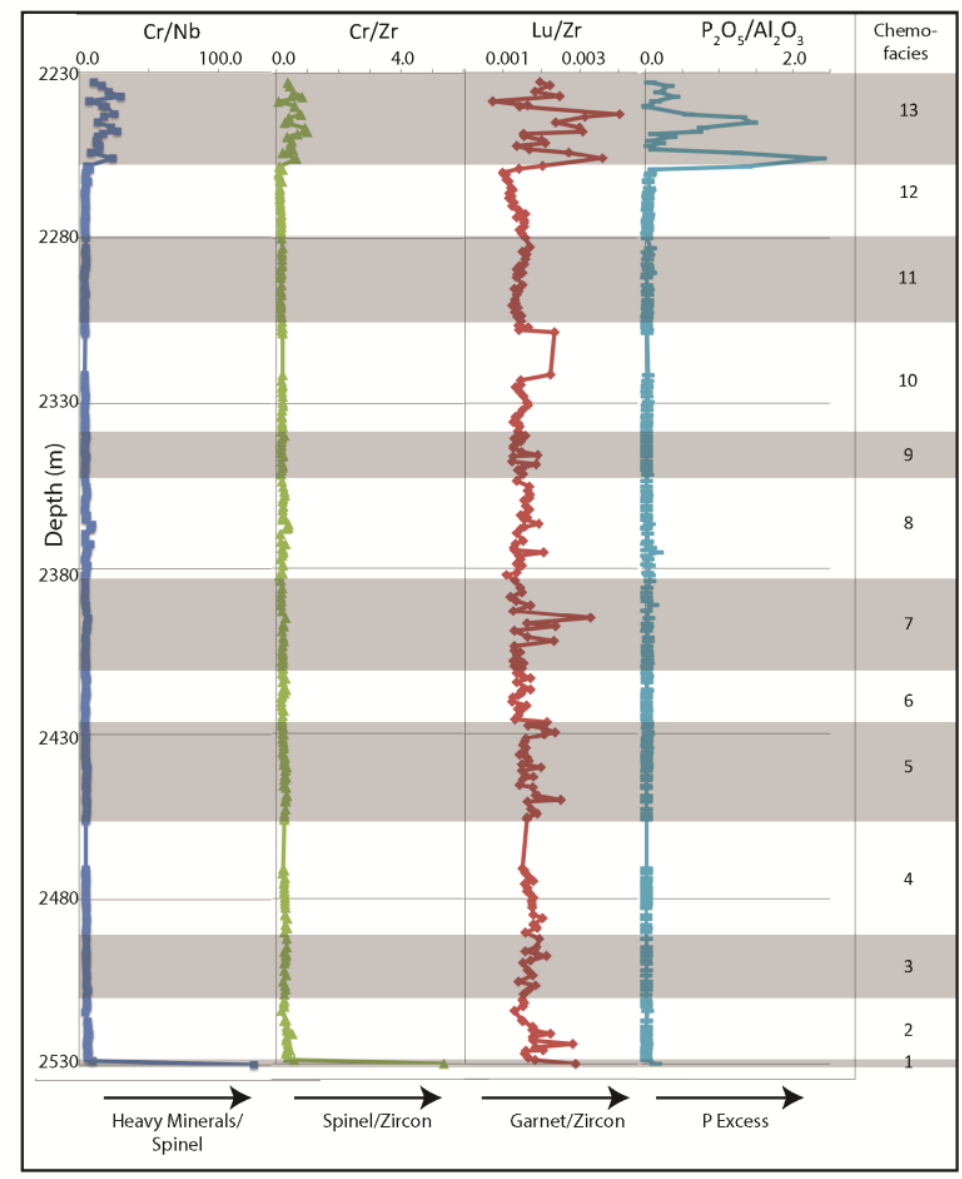

This article is protected by copyright. All rights reserved. 


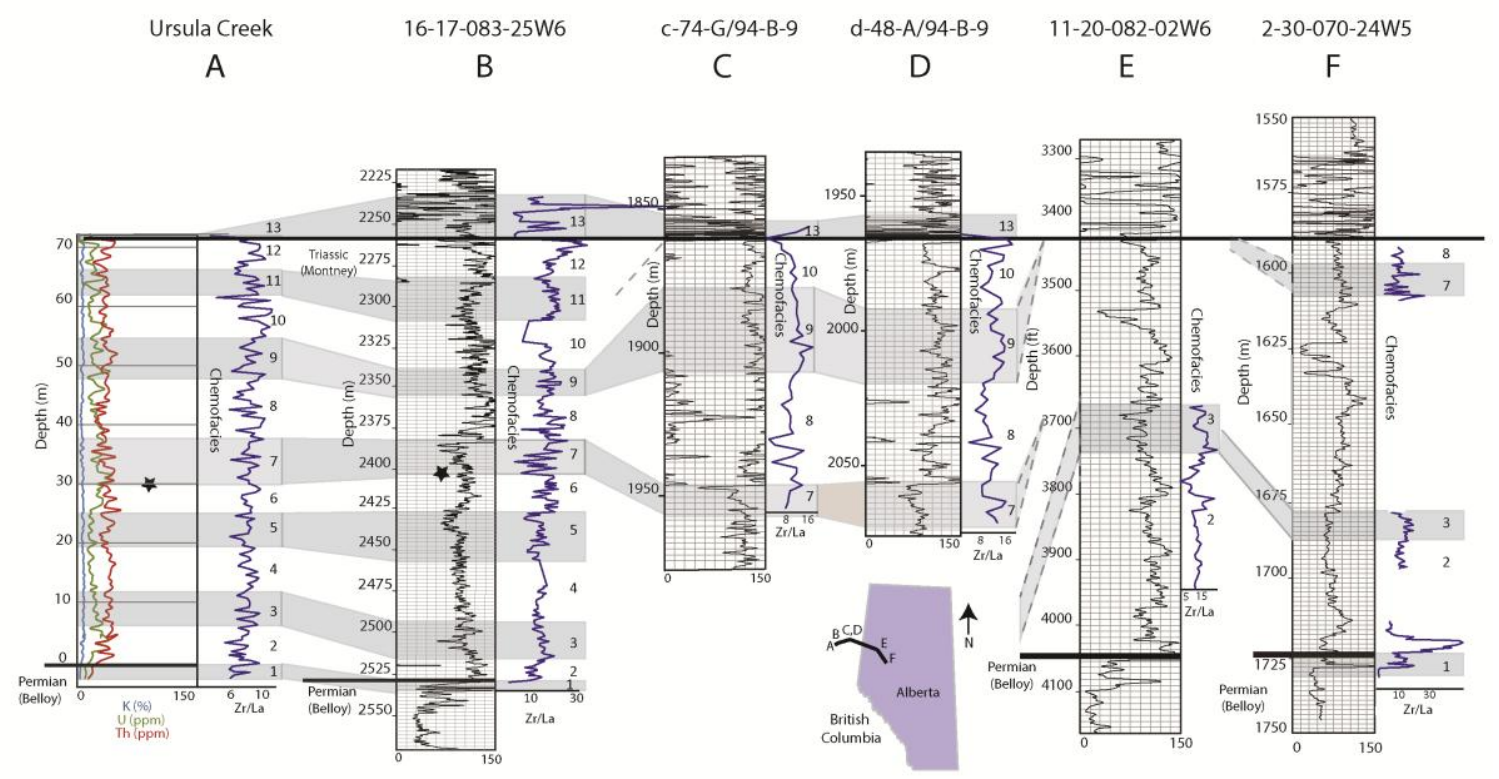

This article is protected by copyright. All rights reserved. 

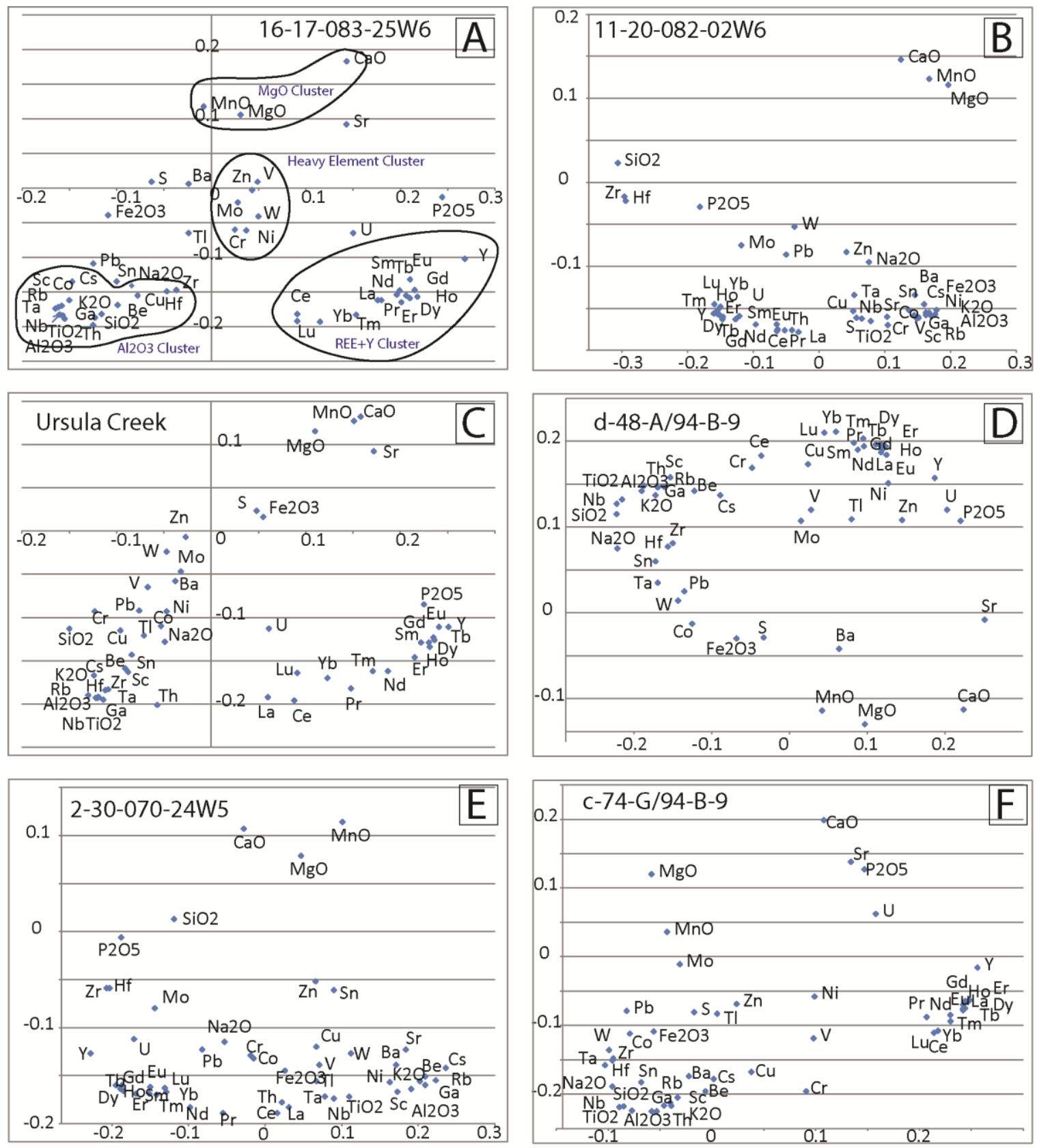

This article is protected by copyright. All rights reserved. 

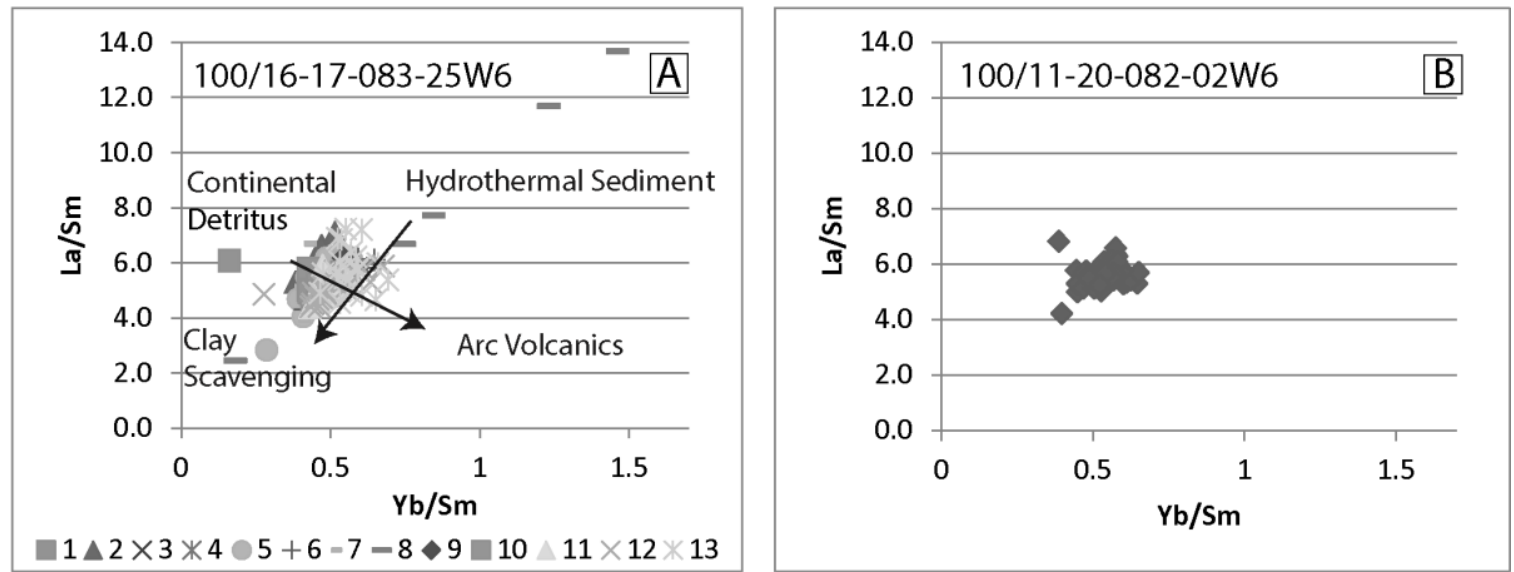

$\square 1 \Delta 2 \times 3 * 4 \bigcirc 5+6-7-8 \diamond 9 \square 10 \Delta 11 \times 12 \times 13$
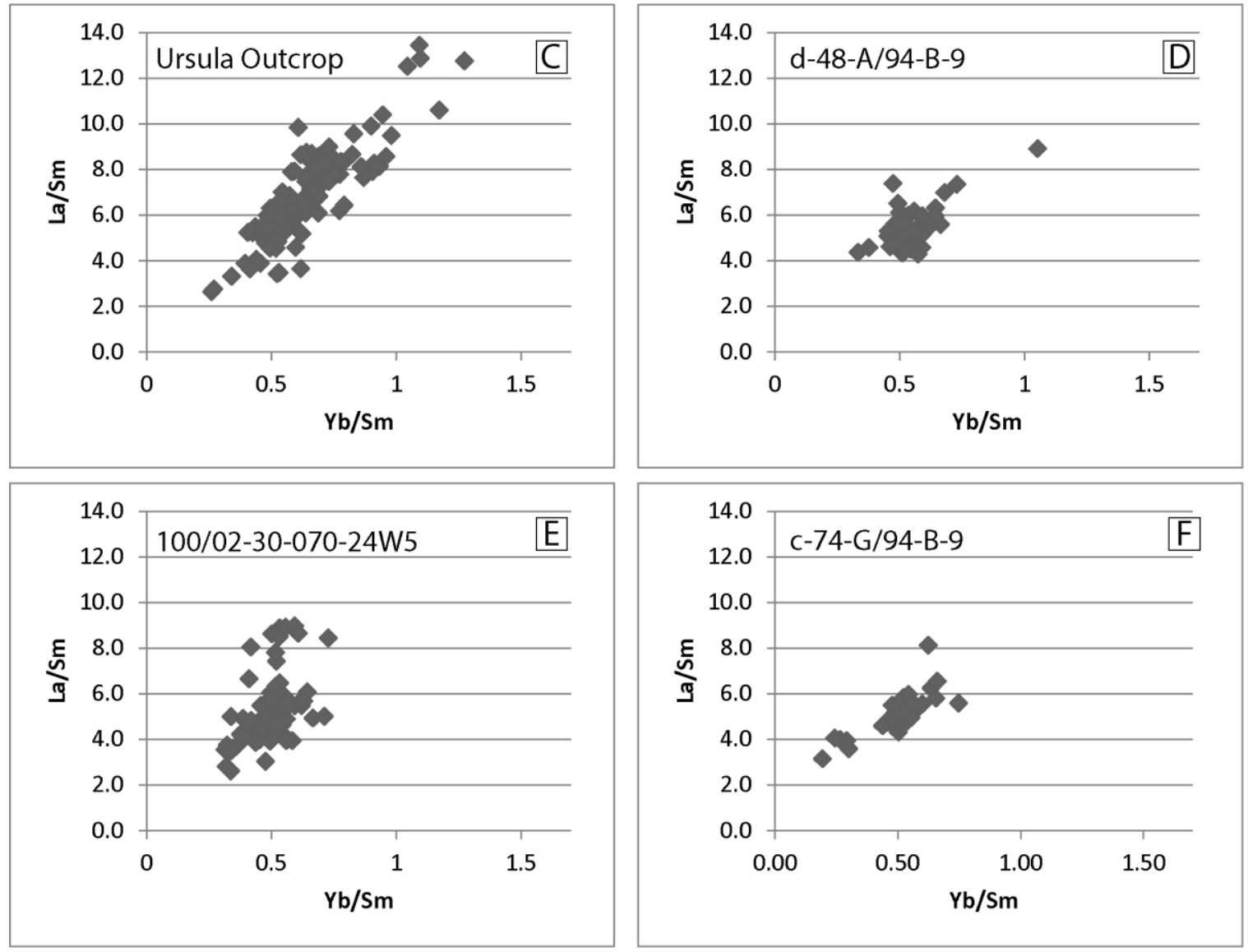

This article is protected by copyright. All rights reserved. 


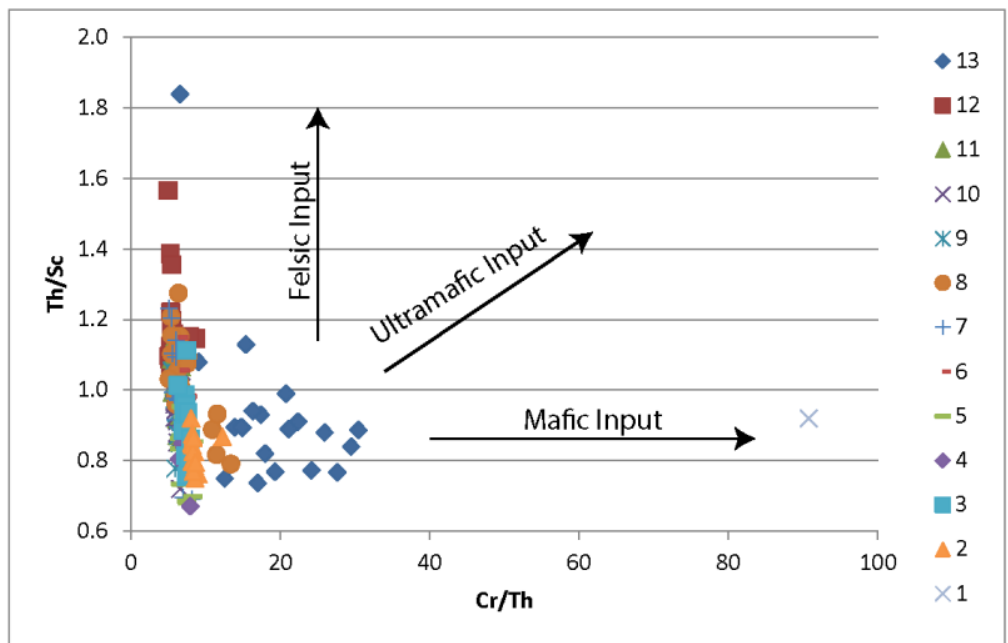

This article is protected by copyright. All rights reserved. 

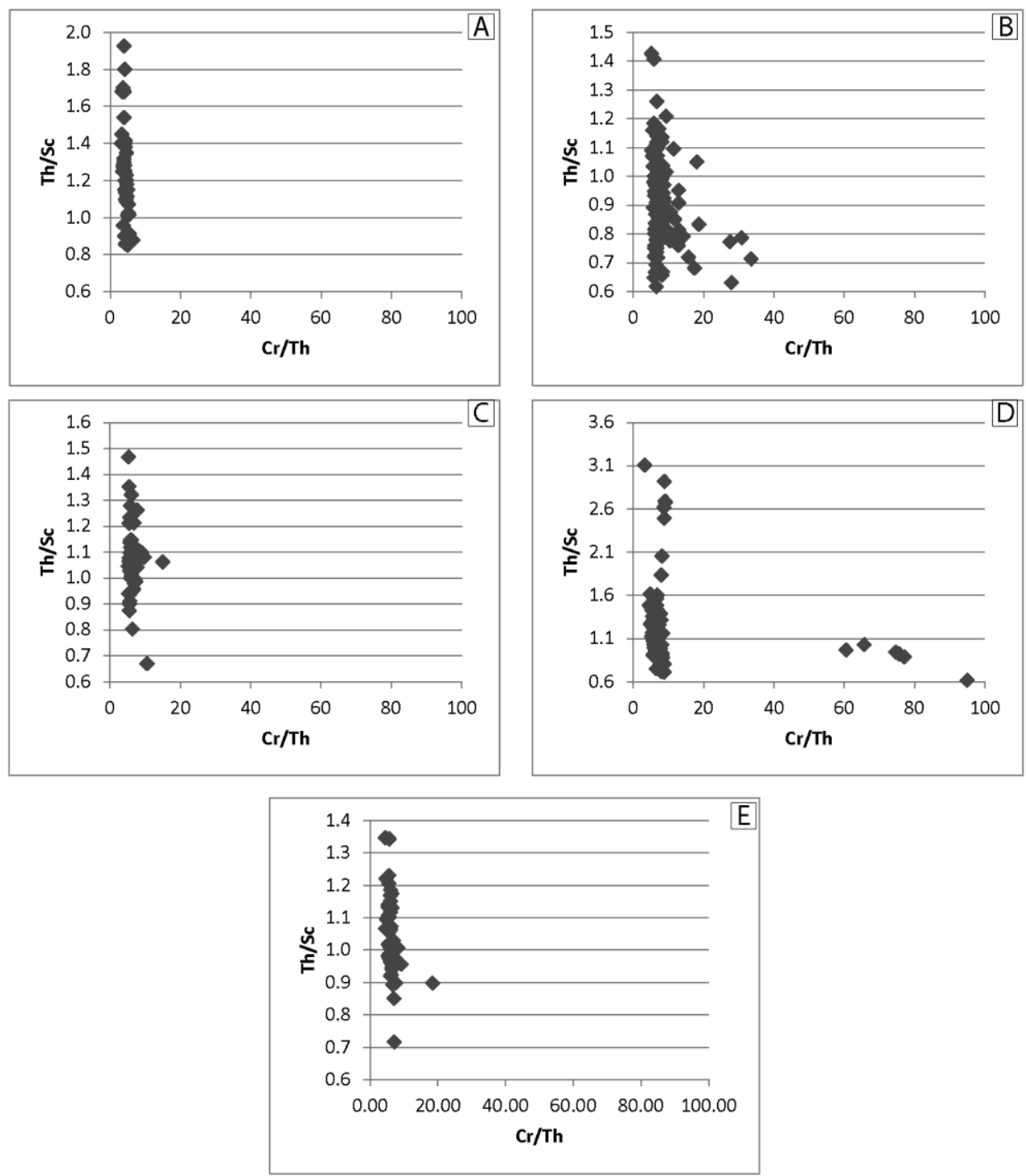

This article is protected by copyright. All rights reserved. 


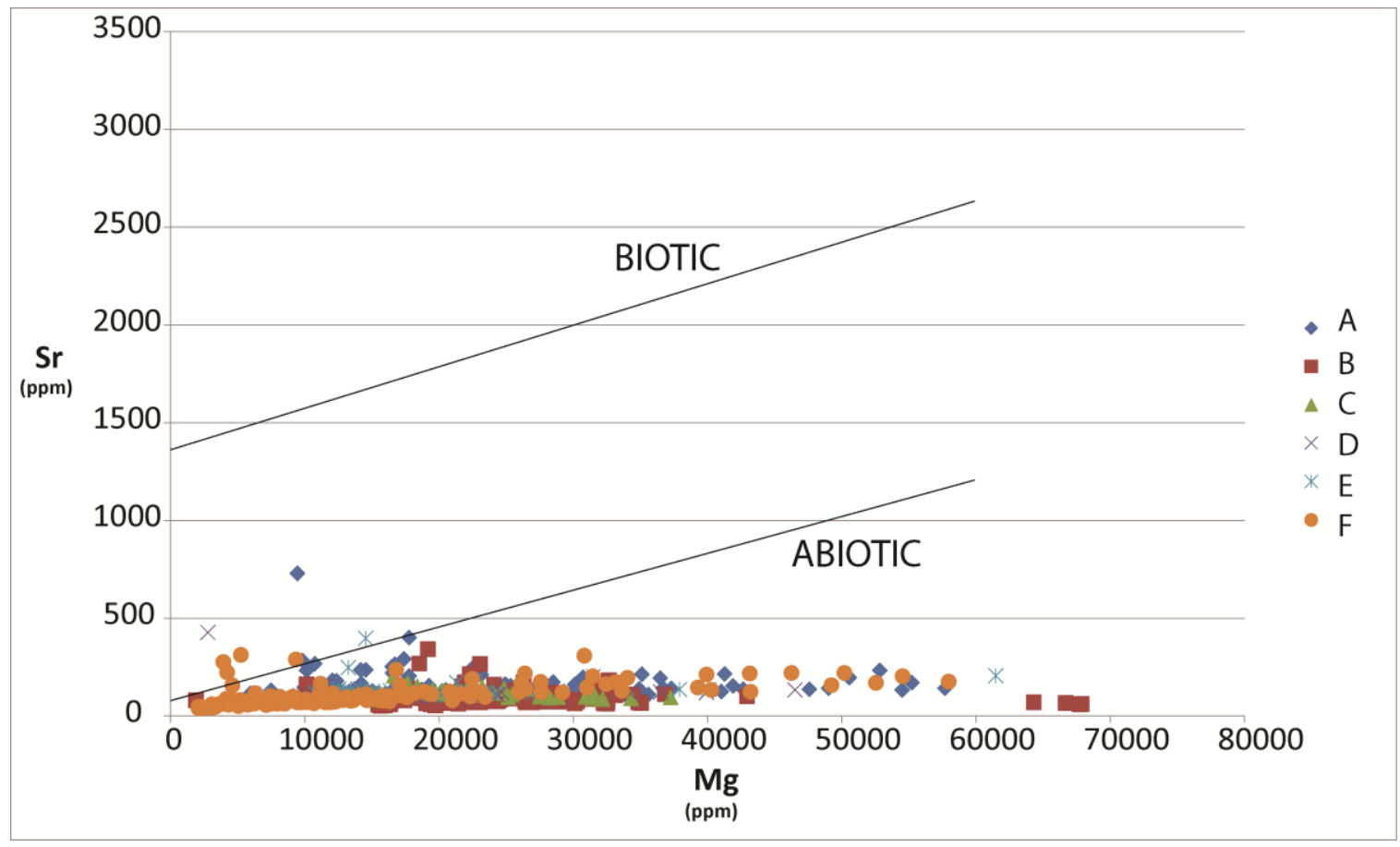

This article is protected by copyright. All rights reserved. 


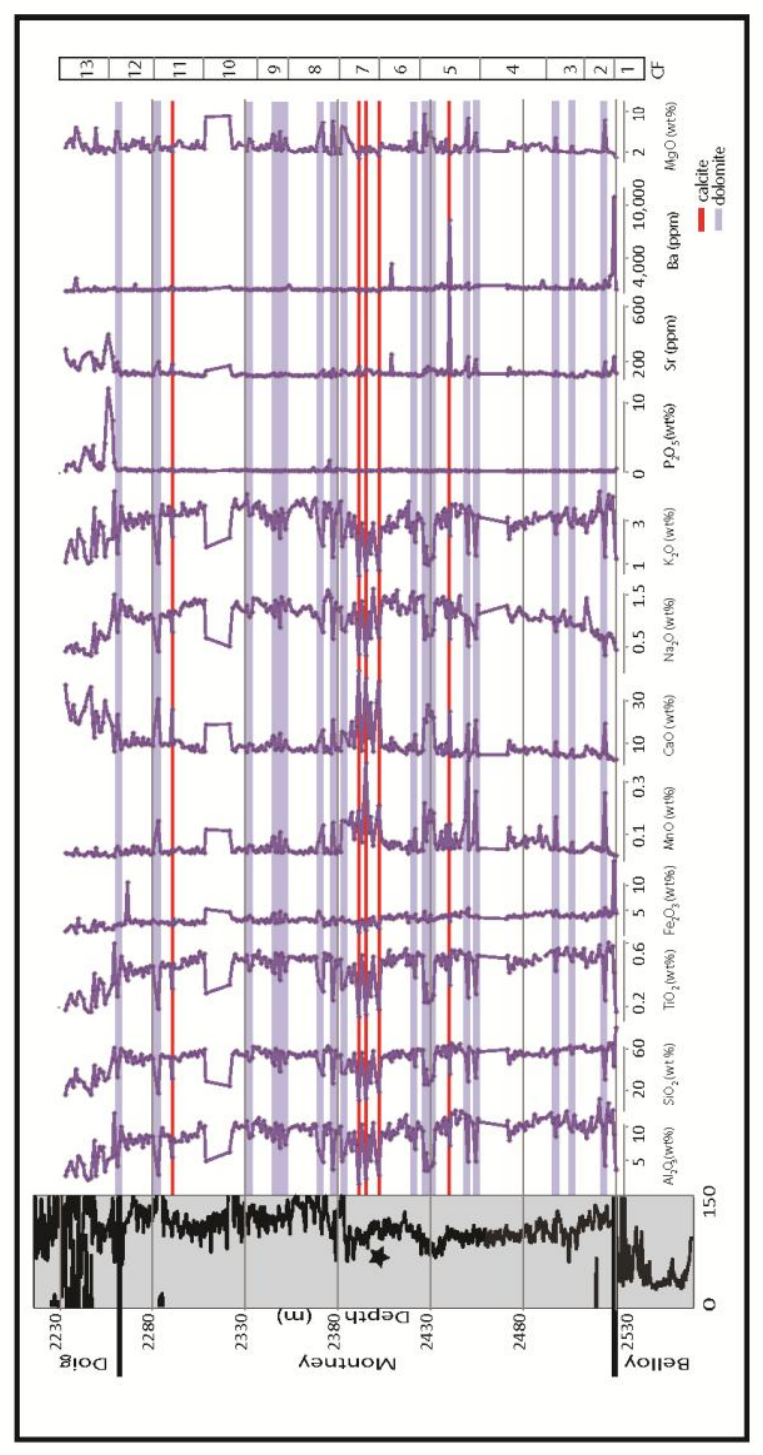

This article is protected by copyright. All rights reserved. 


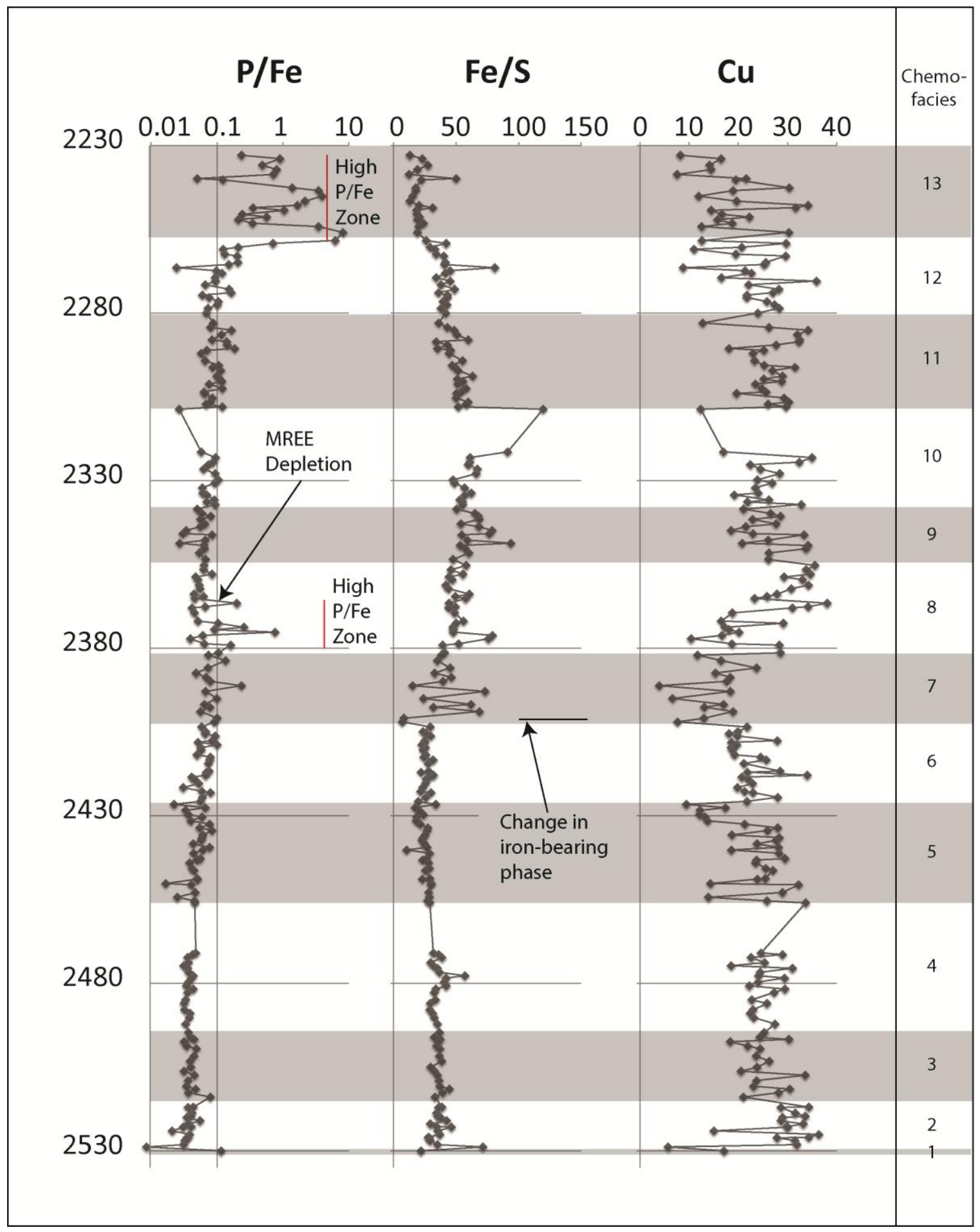

This article is protected by copyright. All rights reserved. 


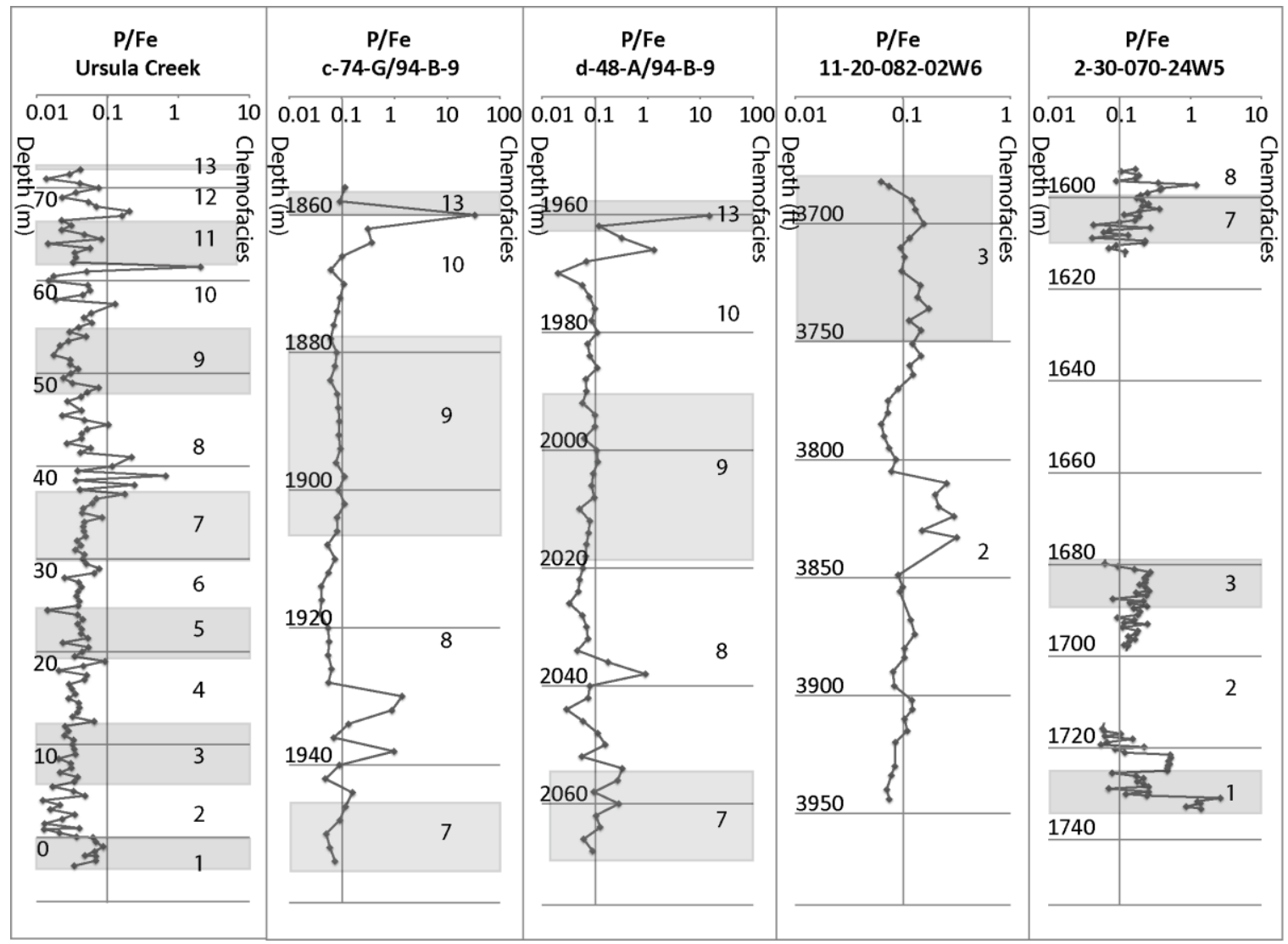

This article is protected by copyright. All rights reserved. 


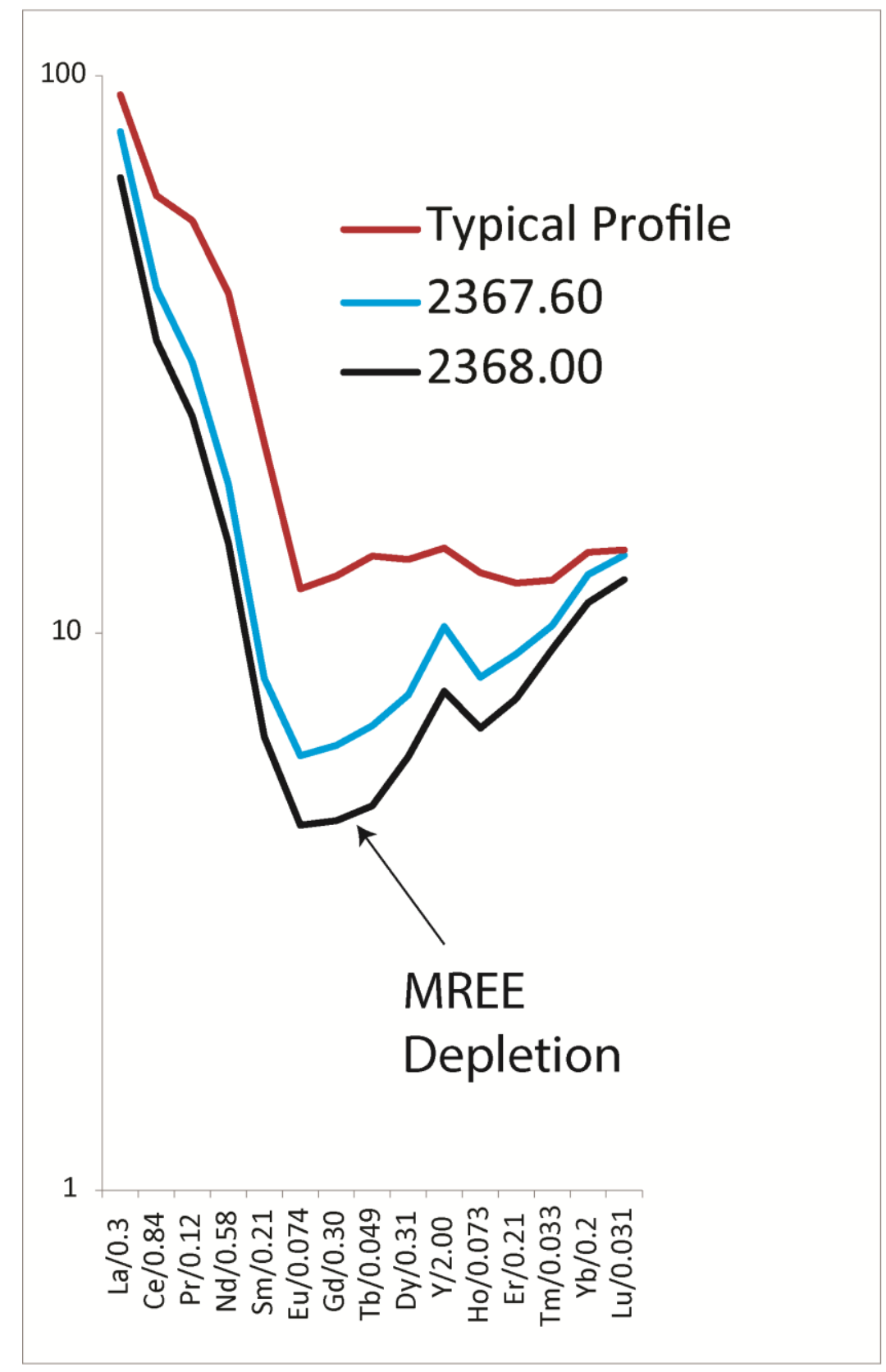

This article is protected by copyright. All rights reserved. 

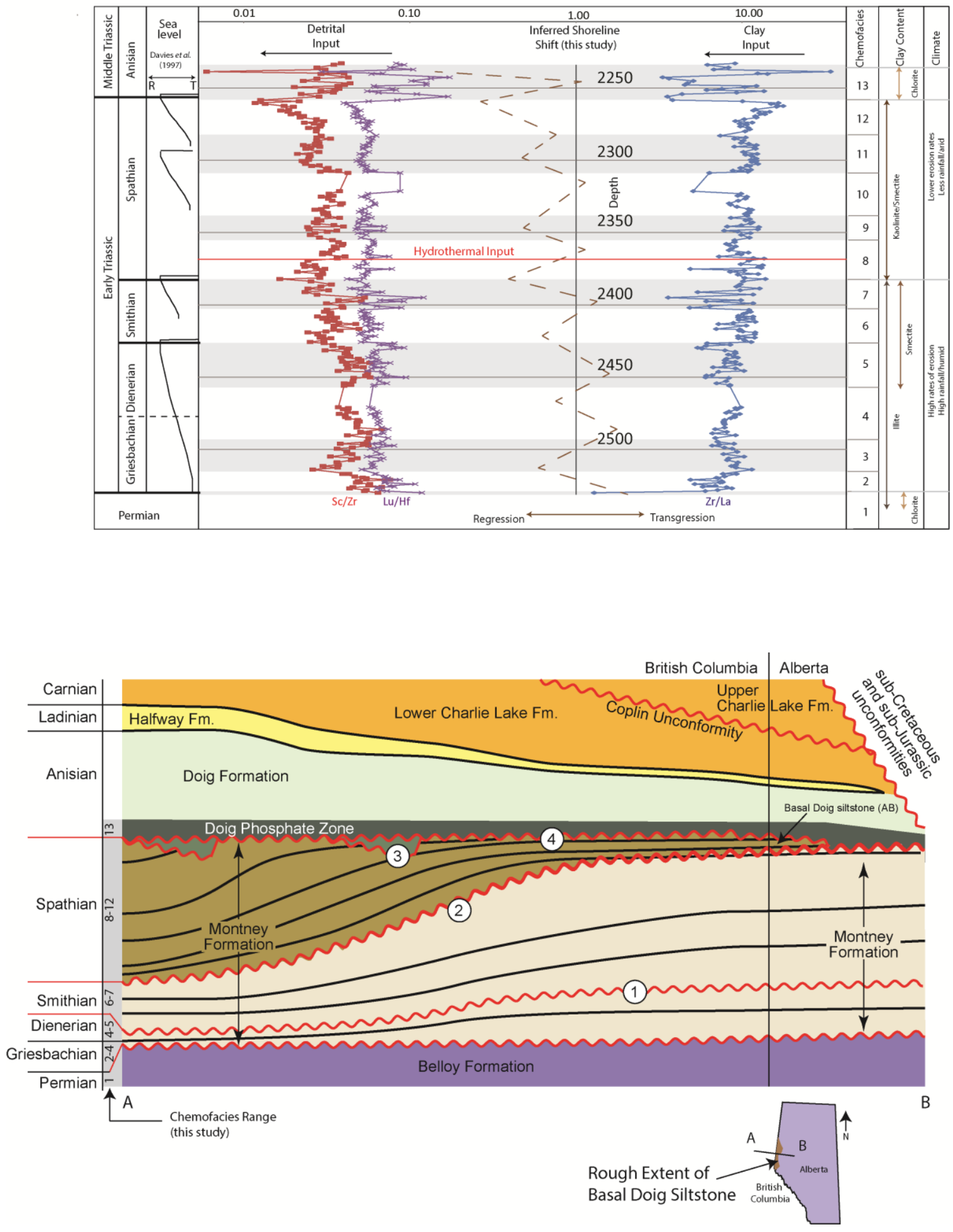

This article is protected by copyright. All rights reserved. 